\title{
LITHOSTRATIGRAPHY OF THE CALICO HILLS FORMATION AND PROW PASS TUFF (CRATER FLAT GROUP) AT YUCCA MOUNTAIN, NEVADA
}

by Thomas C. Moyer and Jeffrey K. Geslin

Science Applications International Corporation, Las Vegas, Nevada

U.S. GEOLOGICAL SURVEY

Open-File Report 94-460

Prepared in cooperation with the

NEVADA OPERATIONS OFFICE,

U.S. DEPARTMENT OF ENERGY under

Interagency Agreement DE-Al08-92NV10874

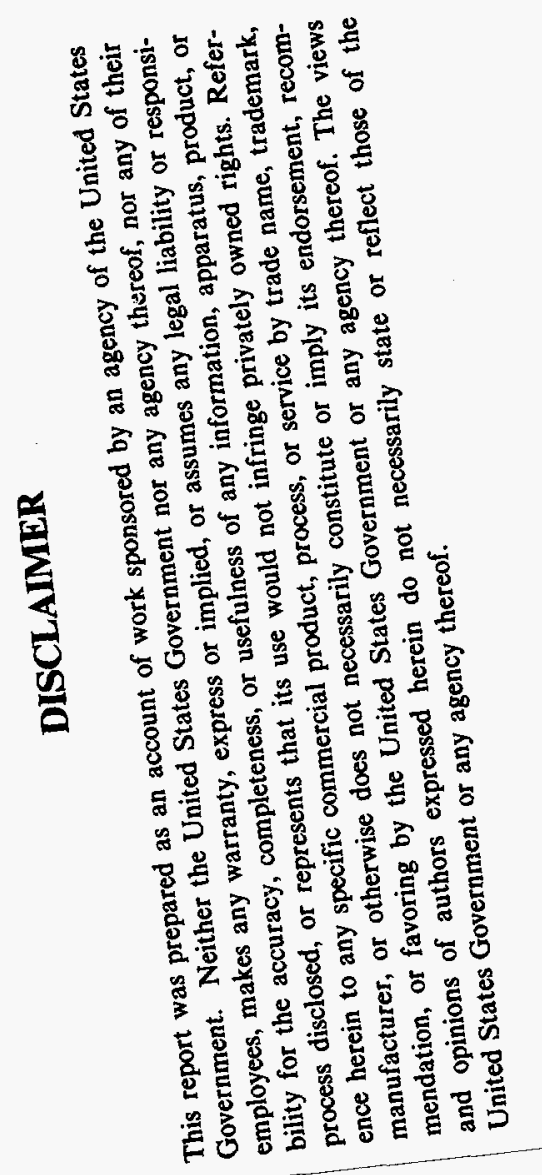

Denver, Colorado

1995

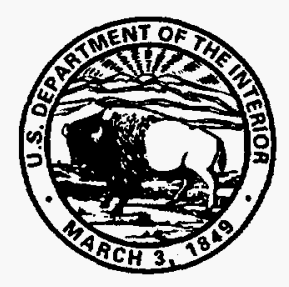




\section{U.S. DEPARTMENT OF THE INTERIOR BRUCE BABBITT, Secretary}

U.S. GEOLOGICAL SURVEY

Gordon P. Eaton, Director

The use of trade, product, industry, or firm names is for descriptive purposes only and does not imply endorsement by the U.S. Government.

For additional information write to: Chief, Earth Science Investigations Program

Yucca Mountain Project Branch U.S. Geological Survey Box 25046, MS 421 Denver Federal Center Denver, CO 80225
Copies of this report can be purchased from: U.S. Geological Survey Earth Science Information Center Open-File Reports Section Box 25286, MS 517 Denver Federal Center Denver, CO 80225 


\section{DISCLAIMER}

Portions of this document may be illegible in electronic image products. Images are produced from the best available original document. 


\section{CONTENTS}

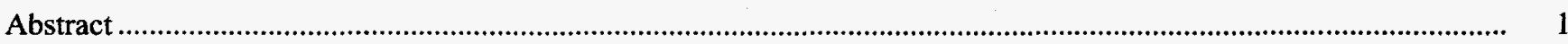

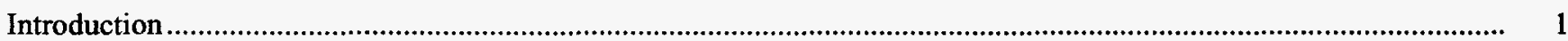

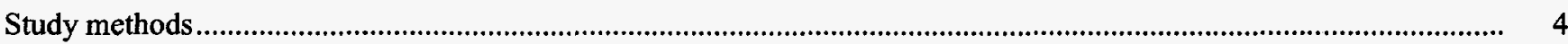

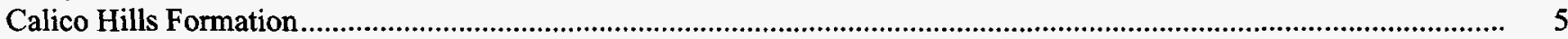

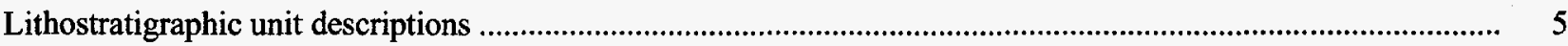

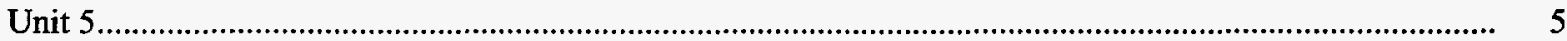

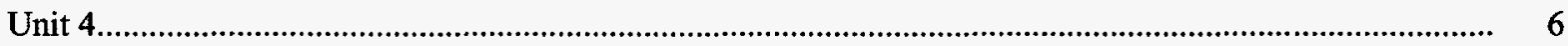

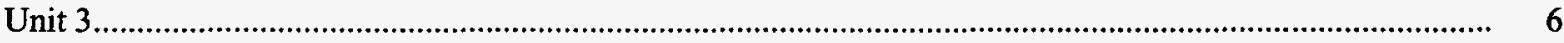

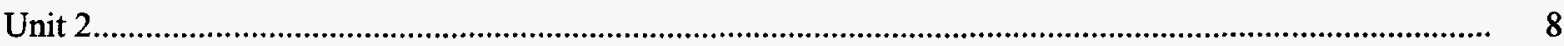

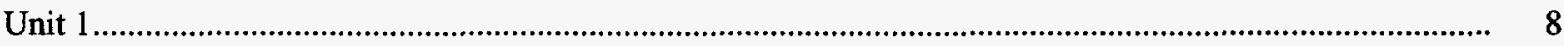

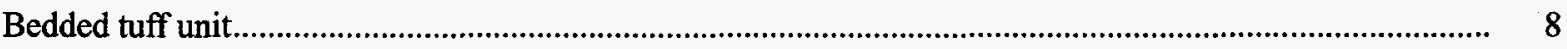

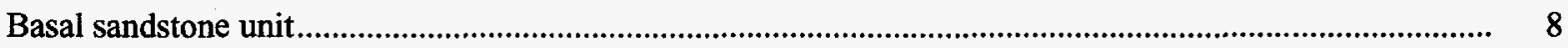

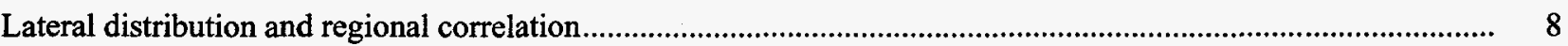

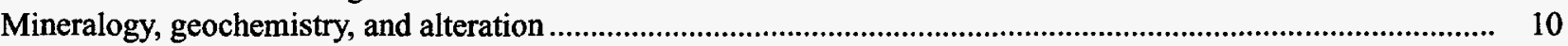

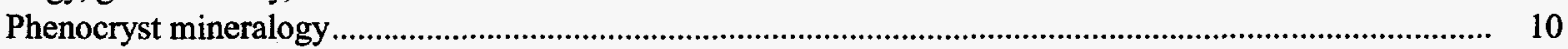

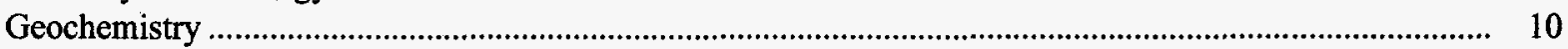

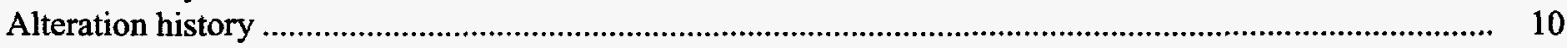

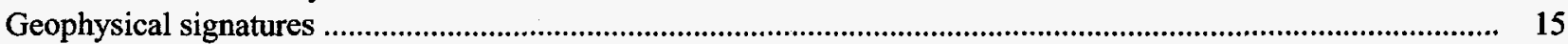

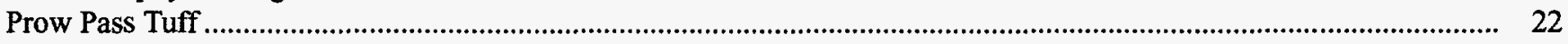

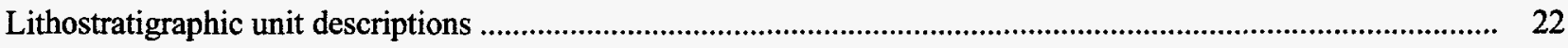

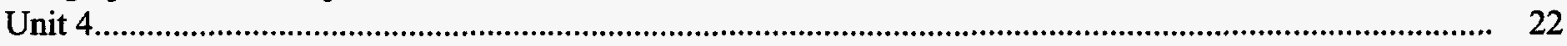

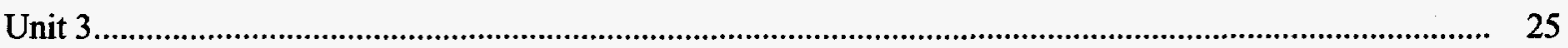

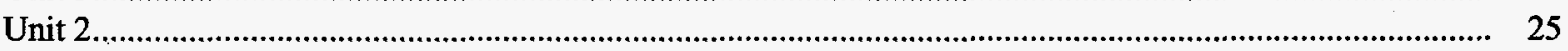

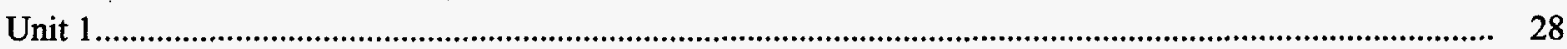

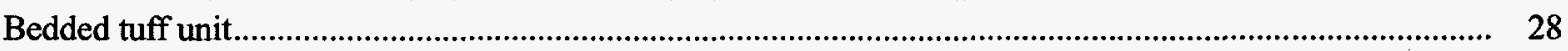

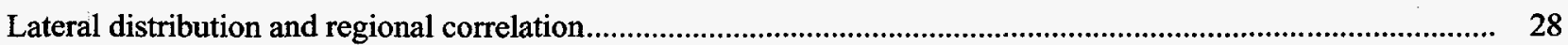

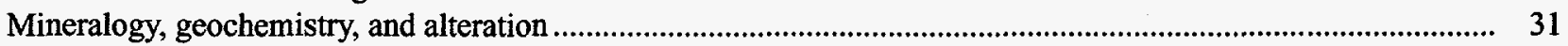

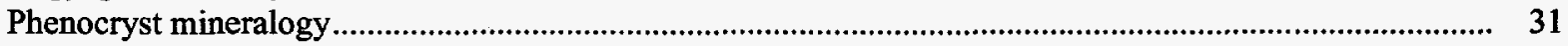

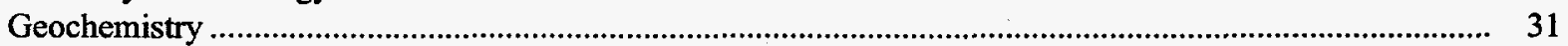

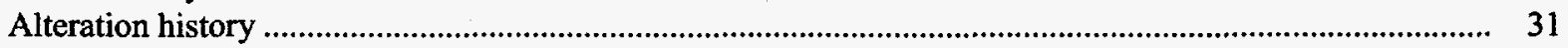

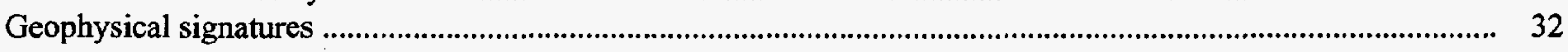

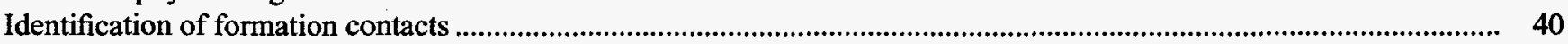

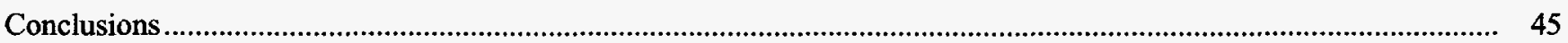

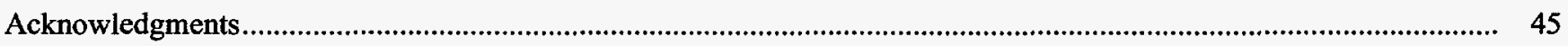

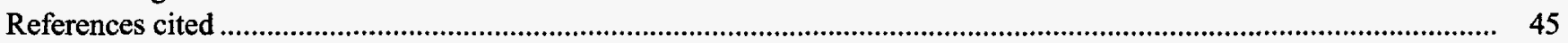

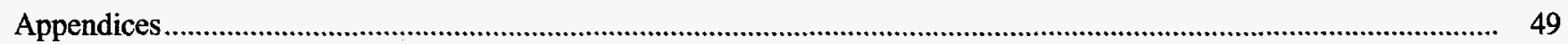

Appendix 1. Description of Calico Hills Formation lithostratigraphic contacts.......................................................... 50

Appendix 2. Unit descriptions of the Calico Hills Formation .............................................................................

Appendix 3. Descriptions of Prow Pass Tuff lithostratigraphic contacts ...................................................................... 53

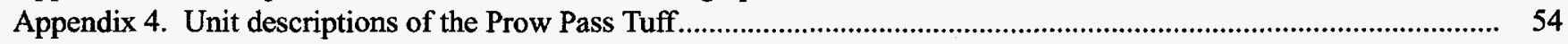

\section{FIGURES}

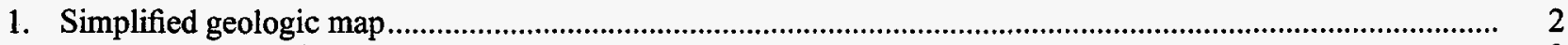

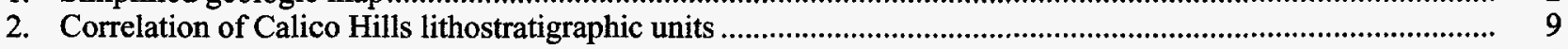

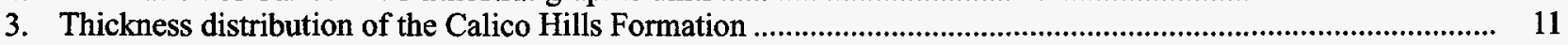

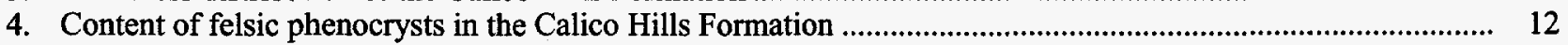

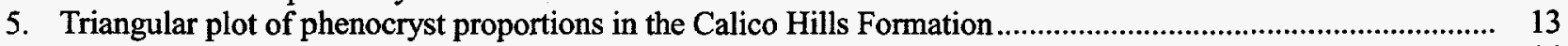

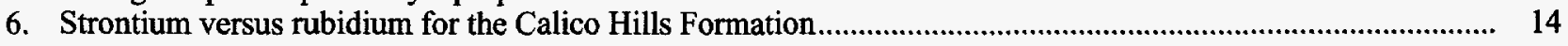

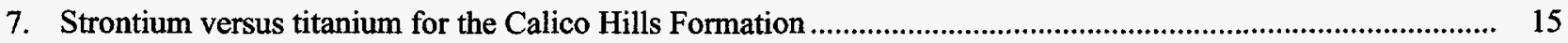

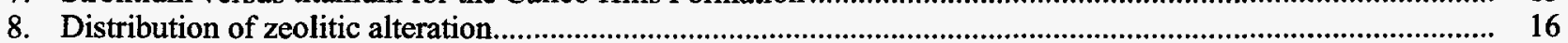


9. Comparison of geophysical signatures and lithostratigraphy ........................................................................ 17

10. Comparison of mineralogy, resistivity, and Calico Hills lithostratigraphy ....................................................... 20

11. Percentage of felsic phenocrysts versus depth in the Prow Pass Tuff.................................................................. 26

12. Average flattening ratios for pumice clasts in Prow Pass unit 3 ….................................................................. 27

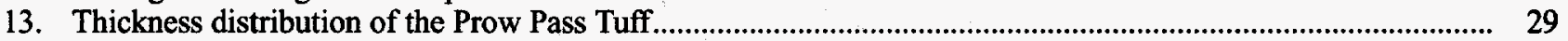

14. Correlation of Prow Pass Tuff lithostratigraphic units .............................................................................. 30

15. Triangular plot of phenocryst proportions in the Prow Pass Tuff ....................................................................

16. Histograms of phenocryst content in the Prow Pass Tuff.......................................................................................... 33

17. Scatter diagrams of Prow Pass Tuff geochemical analyses.........................................................................

18. Geochemistry versus depth compared to Prow Pass lithostratigraphy ..................................................................... 35

19. Geophysical logs compared to Prow Pass lithostratigraphy ...............................................................................

20. Comparison of alteration mineralogy, resistivity, and Prow Pass lithostratigraphy .............................................. 41

21. Comparison of the Calico Hills Formation and Prow Pass Tuff ..............................................................................

\section{TABLES}

1. Summary of stratigraphic relations in the southwest Nevada volcanic field ..................................................... 3

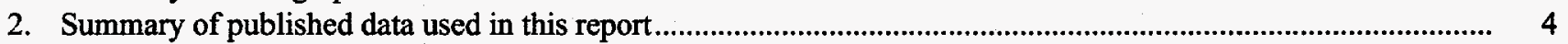

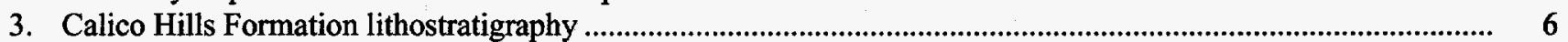

4. Depths to Calico Hills Formation contacts and unit thicknesses in cored boreholes .......................................... 7

5. Brief description of lithostratigraphic units of the Prow Pass Tuff.............................................................................. 23

6. Depths to Prow Pass Tuff contacts in cored boreholes ......................................................................................... 24

\section{CONVERSION FACTORS AND VERTICAL DATUM}

\begin{tabular}{rll}
\hline Multiply & By & To obtain \\
& & \\
millimeter $(\mathrm{mm})$ & 0.03937 & inch \\
centimeter $(\mathrm{cm})$ & 0.3937 & inch \\
$\operatorname{meter}(\mathrm{m})$ & 3.2808 & foot \\
kilometer $(\mathrm{km})$ & 0.6214 & mile \\
\hline
\end{tabular}

Sea level: In this report "sea level" refers to the National Geodetic Vertical Datum of 1929 (NGVD of 1929)-a geodetic datum derived from a general adjustment of the first-order level nets of both the United States and Canada, formerly called Sea Level Datum of 1929. 


\title{
Lithostratigraphy of the Calico Hills Formation and Prow Pass Tuff (Crater Flat Group) at Yucca Mountain, Nevada
}

\author{
By Thomas C. Moyer and Jeffrey K. Geslin
}

\section{Abstract}

Lithostratigraphic relations within the Calico Hills Formation and Prow Pass Tuff (Crater Flat Group) were reconstructed from analysis of core samples and observation of outcrop exposures. Both formations are divided into informal lithostratigraphic units and subunits that can be traced throughout the Yucca Mountain region. Lithostratigraphic units, which have distinct lithologies or macroscopic physical characteristics, have depositional boundaries. Subunits reflect more subtle variations and have contacts defined either by depositional features or other criteria such as degree of welding.

The Calico Hills Formation is composed of five nonwelded pyroclastic units (each formed of one or more pyroclastic-flow deposits) that overlie an interval of bedded tuff and a basal volcaniclastic sandstone unit. The pyroclastic units are distinguished by their matrix color, size and amount of pumice clasts, and size, amount, and type of lithic clasts. The composite apparent thickness of the Calico Hills Formation defines a south-trending paleovalley with an axis that lies east of Yucca Mountain.

The Prow Pass Tuff is divided into four pyroclastic units and an underlying interval of bedded tuff. The pyroclastic units of the Prow Pass Tuff are distinguished by the sizes and amounts of their pumice and lithic clasts and their degree of welding. The most widespread unit is a moderately welded tuff with a compound cooling history. The composite apparent thickness of the pyroclastic units defines a south-trending paleovalley with an axis that lies slightly west of the paleovalley defined by the Calico Hills Formation.

Pyroclastic units of the Prow Pass Tuff are distinguished from those of the Calico Hills For- mation by their phenocryst assemblage, chemical composition, and ubiquitous siltstone lithic clasts. Geophysical logs generally cannot be used to distinguish lithologic units in either formation and are of limited use for identifying the formation contact. Downhole resistivity tends to mirror the content of authigenic minerals, primarily zeolites, in both formations and may be useful for recognizing the vitric-zeolite boundary in the study area. Maps of zeolite distribution illustrate that the bedded tuff and basal sandstone units of the Calico Hills Formation are altered over a wider area than the pyroclastic units of both the Calico Hills Formation and the upper Prow Pass Tuff.

\section{INTRODUCTION}

Yucca Mountain in Nye County, Nevada, is being studied as a potential site for a high-level nuclear waste repository. The study area, which straddles the western boundary of the Nevada Test Site, includes land under the jurisdiction of the U.S. Department of Energy, U.S. Air Force, and Bureau of Land Management. A thick section of Tertiary volcanic rocks overlie Paleozoic sedimentary strata in this region (Byers and others, 1976; fig. 1). The volcanic strata record the evolution of at least seven calderas that comprise the Timber Mountain-Oasis Valley caldera complex of the southwest Nevada volcanic field (Byers and others, 1976; Sawyer and others, 1994).

The potential repository host rock is the voluminous Topopah Spring Tuff, a Miocene ash-flow tuff that erupted from a source in the vicinity of the Claim Canyon caldera at approximately $12.8 \mathrm{Ma}$ (Byers and others, 1976; Sawyer and others, 1994; table 1). The Calico Hills and Wahmonie Formations, which underlie the Topopah Spring Tuff, rest atop the Prow Pass Tuff of the Crater Flat Group (table 1). Zeolitic alteration of the Calico Hills Formation and upper Prow Pass Tuff in the eastern part of the study area (for example, Bish and Vaniman, 1985) makes these forma- 


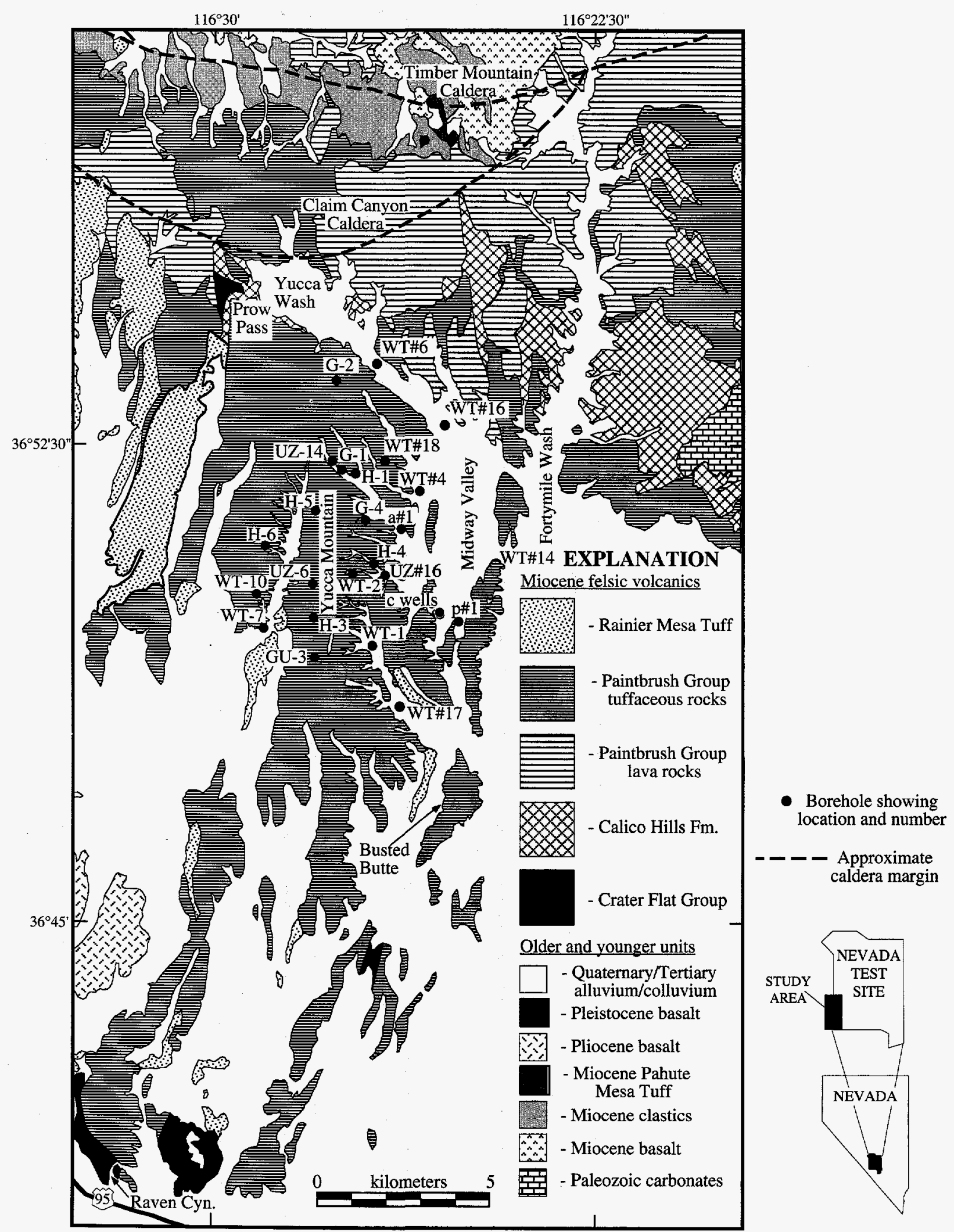

Figure 1. Simplified geologic map showing the distribution of major lithostratigraphic units in the Yucca Mountain area (modified from Frizzell and Shulters, 1990). 
Table 1. Summary of stratigraphic relations in the southwest Nevada volcanic field

\begin{tabular}{|c|c|c|}
\hline Stratigraphic unit & $\begin{array}{c}\text { Age } \\
(\mathrm{Ma})\end{array}$ & Source \\
\hline & & Timber Mountain caldera complex \\
\hline \multicolumn{3}{|l|}{ Paintbrush Group } \\
\hline Tiva Canyon Tuff & 12.7 & Claim Canyon caldera \\
\hline Yucca Mountain Tuff & & Claim Canyon caldera \\
\hline Pah Canyon Tuff & & Uncertain \\
\hline Topopah Spring Tuff & 12.8 & Uncertain \\
\hline Calico Hills Formation & 12.9 & Calico Hills and Area 20 \\
\hline \multirow[t]{2}{*}{ Wahmonie Formation } & 13.0 & Wahmonie volcano \\
\hline & & Silent Canyon caldera complex \\
\hline \multicolumn{3}{|l|}{ Crater Flat Group } \\
\hline Prow Pass Tuff & & Uncertain \\
\hline Bullfrog Tuff & 13.2 & Area 20 caldera \\
\hline Tram Tuff & & Prospector Pass caldera (?) \\
\hline
\end{tabular}

tions an important hydrologic and geologic barrier to radionuclide transport beneath the potential repository site (Broxton and others, 1993).

This report subdivides the Calico Hills Formation and Prow Pass Tuff into informal lithostratigraphic units, provides criteria to identify them in outcrops and boreholes, and describes their distribution in the Yucca Mountain vicinity. Not included in this report is a discussion of the Wahmonie Formation, which is recognized in exposures at Busted Butte (Broxton and others, 1993) and Raven Canyon (Peterman and others, 1993). Although primary deposits of the Wahmonie Formation have not been recovered in core samples in the Yucca Mountain area, the biotite-rich character of a volcaniclastic sandstone at the base of the Calico Hills Formation suggests that it may contain reworked Wahmonie Formation material.

The Calico Hills Formation is a series of rhyolite lavas and tuffs extruded after the Crater Flat Group caldera(s) formed at approximately $12.9 \mathrm{Ma}$ (Christiansen and others, 1977; Sawyer and others, 1994; table 1). Sawyer and others (1994) recently redefined the formation to include the contemporaneous and petrologically similar rhyolite lavas and tuffs of Area 20. Exposures of the Calico Hills Formation in upper Paintbrush Canyon and Fortymile Wash consist of five lava flows and domes that are interstratified with pyroclastic and epiclastic deposits (Buesch and Dickerson, 1993). Lava flows are present in drill cuttings recovered from boreholes in Midway Valley (R.W. Spengler,
1993, written commun.), but are absent in cored boreholes within the potential repository site area. The Calico Hills Formation, which attains a thickness of more than 1,400 feet in the Calico Hills (Frizzell and Schulters, 1990), pinches out southward through the study area and is absent at Raven Canyon (Peterman and others, 1993).

The Prow Pass Tuff is a sequence of variably welded pyroclastic deposits that erupted from an unidentified source between 13.0 and 13.2 Ma (Sawyer and others, 1994). Carr and others (1986a) cited geophysical evidence to hypothesize a caldera source buried beneath basin-fill deposits in Crater Flat. However, Scott (1990) and Sawyer and others (1994) refuted this interpretation in favor of a caldera source north of Yucca Mountain. The Prow Pass Tuff was recently elevated in stratigraphic status from member to formation by Sawyer and others (1994), and is the youngest formation of the Crater Flat Group (table 1). It is exposed in Prow Pass (Carr and others, 1986a), where it underlies tuffs of the Calico Hills Formation (Christiansen and Lipman, 1965) and at Raven Canyon, where it underlies the Wahmonie Formation (Peterman and others, 1993). The Prow Pass Tuff thins gradually southward across the potential repository site area from greater than 540 feet in borehole USW G-2

(Maldonado and Koether, 1983) to approximately 300 feet at Raven Canyon (Peterman and others, 1993). A welded zone within the Prow Pass Tuff led most previous workers to conclude that it is a simple cooling 
unit (for example, Bish and others, 1981), but the more detailed analysis presented herein supports the complex cooling history inferred by Scott and Castellanos (1984). Spengler and others $(1979 ; 1981)$ divided the Prow Pass Tuff into three units; although a tripartite division subsequently was extended to other boreholes (for example, Maldonado and Koether, 1983; Scott and Castellanos, 1984), these early studies recognized lithostratigraphic units that are not correlative.

\section{STUDY METHODS}

Lithostratigraphic relations were reconstructed within the Calico Hills Formation and Prow Pass Tuff from studies of core samples recovered from boreholes USW G-1, G-2, GU-3, G-4, and UZ-14, and UE-25a \#1, c\#1, c\#2, c\#3, and UZ\#16, and from observations of exposures at Prow Pass, Busted Butte, and
Raven Canyon. Preliminary observations were guided by previously published lithologic logs and outcrop descriptions (table 2).

Lithology is the principal criterion used to subdivide the formations. Bedding features, clast size and sorting, and matrix character distinguish the nature of primary volcanic deposits (for example, pyroclastic flow or pyroclastic fall) from their secondary (redeposited) equivalents. Additional criteria used to define the lithostratigraphy included degree of welding, secondary crystallization, alteration, pumice clast content and size, lithic clast content, size and lithology, matrix color, content, and composition, and phenocryst assemblage and content. Visual estimates were made of the amounts of pumice clasts, lithic clasts, and phenocrysts using charts published by Kollmorgen Instruments Corporation (1992). The phenocryst assemblage, alteration minerals, and secondary crystal-

Table 2. Summary of published data used in this report

\begin{tabular}{|c|c|}
\hline \multicolumn{2}{|c|}{ Stratigraphy of Calico Hills Formation (Tac) and Prow Pass Tuff (Tep) } \\
\hline Byers and others, 1976 (Tac, Tcp) & Carr and others, 1986a (Tcp) \\
\hline Broxton and others, 1993 (Tac) & Buesch and Dickerson, 1993 (Tac) \\
\hline Peterman and others, 1993 (Tcp) & Sawyer and others, 1994 (Tac, Tcp) \\
\hline \multicolumn{2}{|c|}{ Lithologic logs of drill core } \\
\hline Spengler and others, 1979 (UE-25a \#1) & Spengler and others, 1981 (USW-G-1) \\
\hline Byers and Warren, 1983 (UE-25J \#13) & Maldonado and Koether, 1983 (USW G-2) \\
\hline Scott and Castellanos, 1984 (USW G-3, GU-3) & Spengler and Chornack, 1984 (USW G-4) \\
\hline Geldon, 1993 (UE-25c \#1, c\#2, c\#3) & Geslin and others, in press (UE-25 UZ\#16) \\
\hline \multicolumn{2}{|c|}{ Lithologic logs of drill cuttings } \\
\hline Bentley and others, 1983 (USW H-5) & Craig and others, 1983 (USW H-6) \\
\hline Rush and others, 1984 (USW H-1) & Thordarson and others, 1984 (USW H-3) \\
\hline Whitfield and others, 1984 (USW H-4) & Whitfield and others, 1993 (USW UZ-6) \\
\hline \multicolumn{2}{|c|}{ Spengler, written commun., 1993 (UE-25 WT\#3, \#16, \#17, \#18; USW WT-1, -2, -7, -10) } \\
\hline \multicolumn{2}{|c|}{ Petrographic descriptions, phenocryst mineralogy and geochemistry } \\
\hline Sykes and others, 1979 (UE-25a \#1) & Bish and others, 1981 (USW G-1) \\
\hline Broxton and others, 1982 (USW G-2) & Caporuscio and others, 1982 (USW G-2) \\
\hline Byers and Warren, 1983 (UE-25J \#13) & Maldonado and Koether, 1983 (USW G-2) \\
\hline Scott and Castellanos, 1984 (USW G-3, GU-3) & Warren and others, 1984 (USW G-1) \\
\hline Caporuscio and others, 1985 (USW G-1) & Broxton and others, 1986 (USW G-2, G-3, GU-3, G-4) \\
\hline Broxton and others, 1989 (USW G-2, GU-3, G-4) & Peterman and others, 1993 (UE-25a \#1) \\
\hline \multicolumn{2}{|c|}{ Peterman and others, 1994, written commun. (USW G-1, G-2, G-3, GU-3, G-4) } \\
\hline \multicolumn{2}{|c|}{ Alteration mineralogy } \\
\hline Bish and others, 1981 (USW G-1) & Caporuscio and others, 1982 (USW G-2) \\
\hline Vaniman and others, 1984 (USW G-3, GU-3) & Bish and Vaniman, 1985 (USW G-4; summary) \\
\hline \multicolumn{2}{|l|}{ Bish and Chipera, 1986 (UE-25a \#1, J\#13: USW G-1) } \\
\hline \multicolumn{2}{|c|}{ Geophysical logs } \\
\hline Spengler and others, 1979 (UE-25a \#1) & Muller and Kibler, 1983 (USW G-1) \\
\hline Muller and Kibler, 1984 (USW G-4) & Nelson and others, 1991 (compilation) \\
\hline
\end{tabular}


lization textures were characterized with the aid of a hand lens or binocular microscope. The colors of pumice clasts, lithic clasts, and matrix were described using Munsell color charts (Geological Society of America, 1991; Kollmorgen Instruments Corporation, 1992).

Diagenetic alteration has obscured the matrix and pumice textures that help to define the degree of welding throughout much of the study area. Thus, the elongation (flattening) of pumice clasts was used to define welding zones. Non- to partially welded zones were visually identified by pumice clasts that are not highly elongated. Moderately or densely welded zones have visually deformed pumice clasts. The robustness of the visual estimates was corroborated by measuring pumice shapes in the welded unit of the Prow Pass Tuff (unit 3) in three boreholes. Units visually identified as non- to partially welded have average pumice flattening ratios (long axis divided by short axis averaged for a minimum of

5 measurements) less than 4 . In contrast, units identified as moderately or densely welded have average pumice flattening ratios greater than 4 .

Both formations are divided into informal lithostratigraphic units and subunits that can be traced throughout the Yucca Mountain region. Lithologic units, which have distinct lithologies or macroscopic physical characteristics, have depositional boundaries. Subunits reflect more subtle variations (for example, lithologically similar flow deposits) and have contacts defined either by depositional features or other criteria such as degree of welding.

Previously published petrographic descriptions, $\mathrm{X}$-ray diffraction data, chemical analyses, and geophysical logs (table 2) supplement our lithostratigraphic observations of the Calico Hills Formation and Prow Pass Tuff and were used to evaluate whether our lithostratigraphic units can be identified from these data in noncored drill holes.

\section{CALICO HILLS FORMATION}

The Calico Hills Formation in the Yucca Mountain region consists of rhyolite lava flows, pyroclasticflow and fall deposits, and volcaniclastic sandstone. Five pyroclastic units, which are given informal numerical designations that increase from the base upward, overlie a bedded tuff unit and a basal sandstone unit. This section summarizes stratigraphic relations within the sequence of pyroclastic and volcaniclastic units that comprise the Calico Hills Formation beneath Yucca Mountain, examines vertical and lateral variations in their lithologic, geochemical, and geophysical properties, and defines criteria to recognize the lithostratigraphic units defined herein. The rhyolite lava flows, which are identified in drill cuttings in the northeastern part of Yucca Mountain (R.W. Spengler, 1993, written commun.) and exposed in the Calico Hills and Fortymile Wash regions (for example, Christiansen and Lipman, 1965; Buesch and Dickerson, 1993), are not included in this discussion.

\section{Lithostratigraphic Unit Descriptions}

The salient features of the Calico Hills Formation lithostratigraphic units are summarized below. Appendixes 1 and 2 provide detailed descriptions of lithologic contacts and lithostratigraphic units. Table 3 summarizes the lithostratigraphy of the Calico Hills Formation, and table 4 gives the depths-to-unit contacts and apparent unit thicknesses in cored boreholes.

The Calico Hills Formation is divided into seven lithostratigraphic units. Included are five pyroclastic units composed mostly of pyroclastic-flow deposits; an underlying bedded tuff unit composed primarily of pyroclastic-fall deposits with subordinate, primary, and reworked pyroclastic-flow deposits; and a basal sandstone unit that contains subordinate, reworked pyroclastic-flow deposits. Pyroclastic units are composed of one or more pyroclastic-flow deposits with similar macroscopic characteristics; flow deposits are separated by locally preserved fall horizons. Pumice- and lithic-fall deposits, which separate the five pyroclastic units, are grouped arbitrarily with the superjacent pyroclastic unit. The five pyroclastic units described in this report may correlate to the five lava flows recognized in exposures of the Calico Hills Formation in Paintbrush Canyon by Buesch and Dickerson (1993).

The pyroclastic units contain from 1 to 12 percent phenocrysts of sanidine, quartz, and plagioclase, with subordinate biotite and $\mathrm{Fe}-\mathrm{Ti}$ oxide minerals. They contain lithic clasts that include devitrifed, commonly flow-foliated, felsic lava, pumiceous tuff, and obsidian. The lithostratigraphic units described herein are zeolitically altered (Caporuscio and others, 1982; Bish and Chipera, 1986); thus, matrix and pumice clast colors will differ in areas where the units have not been zeolitized.

\section{Unit 5}

Unit 5 is a grayish pink to orange pink, non- to partially(?) welded pyroclastic-flow deposit that varies from 0- to 68-feet thick in the boreholes studied at Yucca Mountain. Pumice clasts constitute from 20 to 30 percent of the unit and have a yellowish color that is similar to that of pumice clasts in units 4 and 2. Unit 5 is distinguished from other pyroclastic units by a bimo- 
Table 3. Calico Hills Formation lithostratigraphy

Unit 5 - Non- to partially welded, pumiceous pyroclastic-flow deposit

Slightly elongated pumice clasts; bimodal distribution of pumice clast sizes; 20 to 30 percent pumice. Light colored pumice clasts; moderate reddish-orange to grayish-pink matrix. Base marked by thinly bedded fall deposits.

Unit 4 - Nonwelded, pumiceous pyroclastic-fiow deposit

Volcanic lithic clasts are large $(20$ to $70 \mathrm{~mm})$, isolated or in swarms; prominent clasts of moderate reddish-orange tuff. Light colored pumice clasts; very pale orange to grayish orange-pink matrix. Lithic-poor sections appear similar to unit 2 . Base marked by a heterolithologic sequence of fall deposits.

Unit 3 - Nonwelded, lithic-rich pyroclastic flow deposit

Lithic clasts comprise 5 to 10 percent, locally 10 to 30 percent (near the base and in several intervals within the unit); predominantly devitrified volcanic rocks with local obsidian. Grayish-orange to grayish-yellow or pinkish-gray matrix. The basal lithic-rich fallout is an excellent stratigraphic marker.

Unit 2 - Nonwelded, pumiceous pyroclastic-flow deposit

20 to 40 percent light colored pumice clasts; moderate pink or moderate orange-pink matrix. The fall deposit at the base of the unit contains porcelaneous ash layers.

Unit 1 - Nonwelded, lithic-rich pyroclastic-flow deposit

15 to 20 percent devitrified volcanic lithic clasts near base; lithics decrease upward to 3 to 7 percent. Light colored pumice clasts; grayish orange-pink to light greenish-gray matrix; 7 to 12 percent phenocrysts.

\section{Bedded tuff unit}

Interbedded coarse-grained fallout deposits, pyroclastic-flow deposits (many reworked or with paleosols), and thinly bedded porcelaneous ash-fall deposits. Pyroclastic-flow deposits have 13 to 25 percent phenocrysts.

Basal sandstone unit

Massive to laminated, immature volcaniclastic sandstone; very pale orange to moderate red; medium to coarse grained; accumulations of argillic pumice clasts and rare sedimentary structures including load casts, pinch and swell structures, and flame structures. Locally interbedded with reworked pyroclastic-flow deposits.

dal distribution of pumice clast sizes. Larger pumice clasts (20 to $60 \mathrm{~mm}$ ) are slightly flattened (the flattening ratio is visually estimated at $3: 1$ ), whereas smaller clasts have diameters of 2 to $12 \mathrm{~mm}$ and equidimensional shapes. Lithic clasts of grayish-brown, devitrified volcanic rock, mostly smaller than $10 \mathrm{~mm}$, compose from 2 to 5 percent of the unit. The lower contact is a sequence of thinly bedded, fine-grained fall deposits that are less than 2-feet thick.

\section{Unit 4}

Unit 4 is a nonwelded, pumiceous pyroclasticflow deposit that may be light gray, shades of grayish pink, or moderate orange pink. It has an apparent thickness that varies from 0 to 188 feet in the boreholes studied at Yucca Mountain. Pumice clasts, which compose from 10 to 30 percent of unit, typically have diameters of 15 to $30 \mathrm{~mm}$ and yellowish to white colors. Lithic clasts comprise only 1 to 5 percent of the unit but help to distinguish unit 4 from other pyroclastic units. Particularly distinctive are large (up to $70 \mathrm{~mm}$ ) volcanic lithic clasts, mostly devitrified lava in shades of brown or gray, that occur in swarms or as isolated clasts, and clasts of reddish-orange, crystal-rich, pumi- ceous tuff. The latter compose approximately 10 to 30 percent of the lithic population in unit 4 but are rare in units 3 and 2. Where lithic-poor, unit 4 can be confused with unit 2 because they have similar matrix and pumice clast colors. However, the underlying unit 3 is the most laterally extensive lithostratigraphic unit in the Calico Hills Formation at Yucca Mountain (see below) and provides stratigraphic context that allows their differentiation. The base of unit 4 is marked by a heterolithologic sequence of thinly bedded fall deposits, reworked pyroclastic-flow deposits, and tuffaceous sandstone that has an aggregate thickness of less than 14 feet.

\section{Unit 3}

Unit 3 is a nonwelded, lithic-rich pyroclasticflow deposit that may be shades of very pale orange, grayish orange, orange pink, or grayish yellow. The apparent thickness of this unit varies from 72 to 328 feet in the boreholes studied at Yucca Mountain. White, yellowish, or pinkish pumice clasts compose from 10 to 25 percent of the unit (locally 30 to 40 percent near the upper contact). Unit 3 contains from 5 to 10 percent lithic clasts, with localized zones in which 
Table 4. Depths to Calico Hills Formation contacts and unit thicknesses in cored boreholes

[Contacts are located at the base of the fallout deposit below the pyroclastic-flow deposits of each pyroclastic unit. All measurements are in feet; ----, no data; n.p., unit not present in core]

\begin{tabular}{|c|c|c|c|c|c|c|c|c|c|c|c|c|c|c|}
\hline \multirow[b]{2}{*}{ Borehole unit } & \multicolumn{2}{|c|}{ USW G-2 } & \multicolumn{2}{|c|}{ USW UZ-14 } & \multicolumn{2}{|c|}{ USW G-1 } & \multicolumn{2}{|c|}{ USW G-4 } & \multicolumn{2}{|c|}{ UE-25a \#1 } & \multicolumn{2}{|c|}{ UE-25 UZ \#16 } & \multicolumn{2}{|c|}{ USW GU-3 } \\
\hline & Depth & $\begin{array}{l}\text { Thick- } \\
\text { ness }\end{array}$ & Depth & $\begin{array}{l}\text { Thick- } \\
\text { ness }\end{array}$ & Depth & $\begin{array}{l}\text { Thick- } \\
\text { ness }\end{array}$ & Depth & $\begin{array}{l}\text { Thick- } \\
\text { ness }\end{array}$ & Depth & $\begin{array}{l}\text { Thick- } \\
\text { ness }\end{array}$ & Depth & $\begin{array}{l}\text { Thick- } \\
\text { ness }\end{array}$ & Depth & $\begin{array}{l}\text { Thick- } \\
\text { ness }\end{array}$ \\
\hline Paintbrush Group & & & & & & & & & & & & & & \\
\hline Pre-Tpt bedded tuff & $1,757.0$ & --- & $1,420.2$ & --- & $1,425.5$ & -- & $1,409.4$ & $-\cdots$ & $1,368.6$ & $-\cdot-$ & $1,201.0$ & --- & $1,412.5$ & \\
\hline Calico Hills Formation & & & & & & & & & & & & & & \\
\hline Unit 5 & $1,825.2$ & 68.2 & n.p. & $\cdots$ & n.p. & -.-- & $1,426.3$ & 16.9 & $1,386.2$ & 17.6 & n.p. & --- & n.p. & $-\cdots$ \\
\hline Basal fallout deposit & & 0.5 & & $\ldots$ & & ---- & & 1.8 & & 1.3 & & $-\cdots$ & & -.-- \\
\hline Unit 4 & $2,013.2$ & 188.0 & n.p. & $\cdots$ & n.p. & --- & $1,451.8$ & 25.5 & $1,457.4$ & 71.2 & $1,258.6$ & 57.6 & n.p. & $\cdots$ \\
\hline Basal fallout deposit & & 14.2 & & $\ldots$ & & -..- & & 1.4 & & 4.4 & & 0.2 & & $\cdots$ \\
\hline Unit 3 & $2,341.5$ & 328.3 & $1,492.7$ & 72.5 & $1,540.7$ & 115.2 & $1,563.9$ & 112.1 & $1,585.5$ & 128.1 & $1,341.0$ & 82.4 & $1,506.3 \dagger$ & 93.8 \\
\hline Basal fallout deposit & & 4.8 & & 1.1 & & 1.5 & & 3.3 & & 3.1 & & 3.0 & & $\cdots$ \\
\hline Unit 2 & $2,385.2$ & 43.7 & $1,653.4$ & 160.7 & $1,695.6$ & 154.9 & $1,705.4$ & 141.5 & $1,764.0$ & 178.5 & $1,455.4$ & 114.4 & n.p. & $\ldots$ \\
\hline Basal fallout deposit & & 1.2 & & 1.4 & & 2.8 & & -..- & & 1.4 & & $\ldots$ & & $\ldots$ \\
\hline Unit 1 & $2,576.7$ & 191.5 & $1,694.0$ & 40.6 & $1,736.4$ & 40.8 & n.p. & $\ldots$ & $1,789.3$ & 25.3 & n.p. & $\ldots$ & n.p. & $\cdots$ \\
\hline Bedded tuff unit & $2,704.7$ & $128.0^{*}$ & $1,735.4$ & 41.4 & $1,781.0$ & 44.6 & $1,750.0$ & 44.6 & $1,820.3$ & 31.0 & $1,485.0$ & 29.6 & $1,552.4$ & 46.1 \\
\hline $\begin{array}{l}\text { Basal sand-stone unit } \\
\text { Prow Pass Tuff }\end{array}$ & n.p. & --- & $1,750.2$ & 14.8 & $1,799.0$ & 18.0 & $1,762.7$ & 12.7 & $1,832.2$ & 11.9 & n.p. & $-\cdots$ & $1,553.9$ & 1.5 \\
\hline
\end{tabular}


lithic concentrations are from 10 to 50 percent. Lithic clasts are primarily devitrified lava in shades of blackish red, reddish brown, grayish brown, and light gray. Subordinate, but distinctive, clasts of black obsidian, and rare clasts of reddish-orange tuff occur throughout the unit. Although the matrix color and pumice content and color of unit 3 are similar to those of unit 1 , the units can be differentiated by their phenocryst contents ( 1 to 6 percent in unit 3 compared to 1 to 12 percent in unit 1 ), and the presence of obsidian in unit 3. A lithic-rich fallout deposit at the base of unit 3 is a marker horizon observed in core from all boreholes except USW GU-3. The fallout is less than 3-feet thick.

\section{Unit 2}

Unit 2 is a nonwelded, pumiceous pyroclasticflow deposit that has a distinctive pink to orange-pink matrix. It has an apparent thickness that varies from 0 to 178 feet in the boreholes studied at Yucca Mountain. Pumice clasts compose from 20 to 40 percent of the unit, are typically smaller than $20 \mathrm{~mm}$, and yellowish, pale orange, or white. Lithic clasts are sparse (from 1 to 3 percent, locally 3 to 5 percent), mostly devitrified lava, and rarely reddish-orange tuff. Several thin (less than 0.5 feet) fallout deposits occur in the middle of unit 2. Fallout deposits at the base of unit 2 are ash-rich, have a distinctive, porcelaneous appearance, and are less than 3-feet thick.

\section{Unit 1}

Unit 1 is a nonwelded, lithic-rich, pyroclasticflow deposit that occurs in shades of pinkish gray or greenish gray. White- to pale greenish-yellow pumice clasts compose from 10 to 15 percent of the unit. It is from 0- to 191-feet thick in the boreholes studied at Yucca Mountain. The amount of lithic clasts increases downward from 3 to 7 percent near the top of the unit, to 15 to 20 percent near its base. Lithic clasts, mostly grayish-red or moderate brown, sparsely porphyritic lava, typically are smaller than $15 \mathrm{~mm}$, but locally vary up to $60 \mathrm{~mm}$. Phenocrysts generally compose from 7 to 12 percent (locally 1 to 7 percent) of unit 1 . The phenocryst content of unit 1 is lower than that of pyroclastic-flow deposits in the subjacent bedded tuff unit (10 to 25 percent), but is typically higher than in the overlying pyroclastic units.

\section{Bedded Tuff Unit}

The bedded tuff unit is a distinctive, complex stratigraphic package containing abundant coarse- grained fallout deposits and subordinate primary and reworked pyroclastic-flow deposits and ash-fall deposits. The unit varies in total apparent thickness from 30 to $128 \mathrm{feet}$ in the boreholes studied at Yucca Mountain. Interbedded pyroclastic-flow deposits typically are from 5- to 10-feet thick, contain abundant phenocrysts (10 to 25 percent) and are brown, clay-rich and (possibly) reworked. This unit also contains thin, porcelaneous ash-fall deposits.

\section{Basal Sandstone Unit}

The basal unit of the Calico Hills Formation is an immature, volcaniclastic sandstone that is from 0 - to 18-feet thick. This laminated to massive unit locally contains load casts, pinch and swell structures, and flame structures. It varies from very pale orange to moderate red, is medium- to coarse-grained, and poorly sorted, with abundant lithic clasts and swarms of argillically altered pumice clasts. Rare, interbedded pyroclastic-flow deposits are reworked, typically brown and clay-rich, with subrounded to subangular phenocrysts and pumice clasts.

\section{Lateral Distribution and Regional Correlation}

The lithostratigraphic units of the Calico Hills Formation were correlated through eight cored boreholes at Yucca Mountain (fig. 2). Outcrops of the Calico Hills Formation were examined at Prow Pass and Busted Butte (fig. 1) to investigate if the lithostratigraphic units could be identified in field exposures. Pyroclastic units 2 and 3 and the bedded tuff unit are present in all boreholes except USW GU-3 (see below). The basal sandstone and pyroclastic units 1,4 , and 5 are laterally discontinuous (fig. 2).

In borehole USW GU-3, the bedded tuff unit is overlain by vitric tuffaceous material. Although mostly disaggregated, the brown, clay-rich appearance of these deposits suggests that they are a distal, reworked facies of the pyroclastic-flow deposits to the north. Abundant pumice clasts (Scott and Castellanos, 1984) and glass shards that were not degraded to the point of destruction indicate minimal mechanical reworking and short transport distances. Obsidian lithic clasts in these deposits permit a tentative correlation to pyroclastic unit 3 , which contains obsidian clasts in USW UZ-14. However, it is also possible that this unit correlates to more than one pyroclastic unit.

The outcrop of Calico Hills Formation at Busted Butte (Broxton and others, 1993) is a sequence of poorly lithified, brown, clay-rich deposits that locally contain black obsidian clasts. It is similar to the depos- 


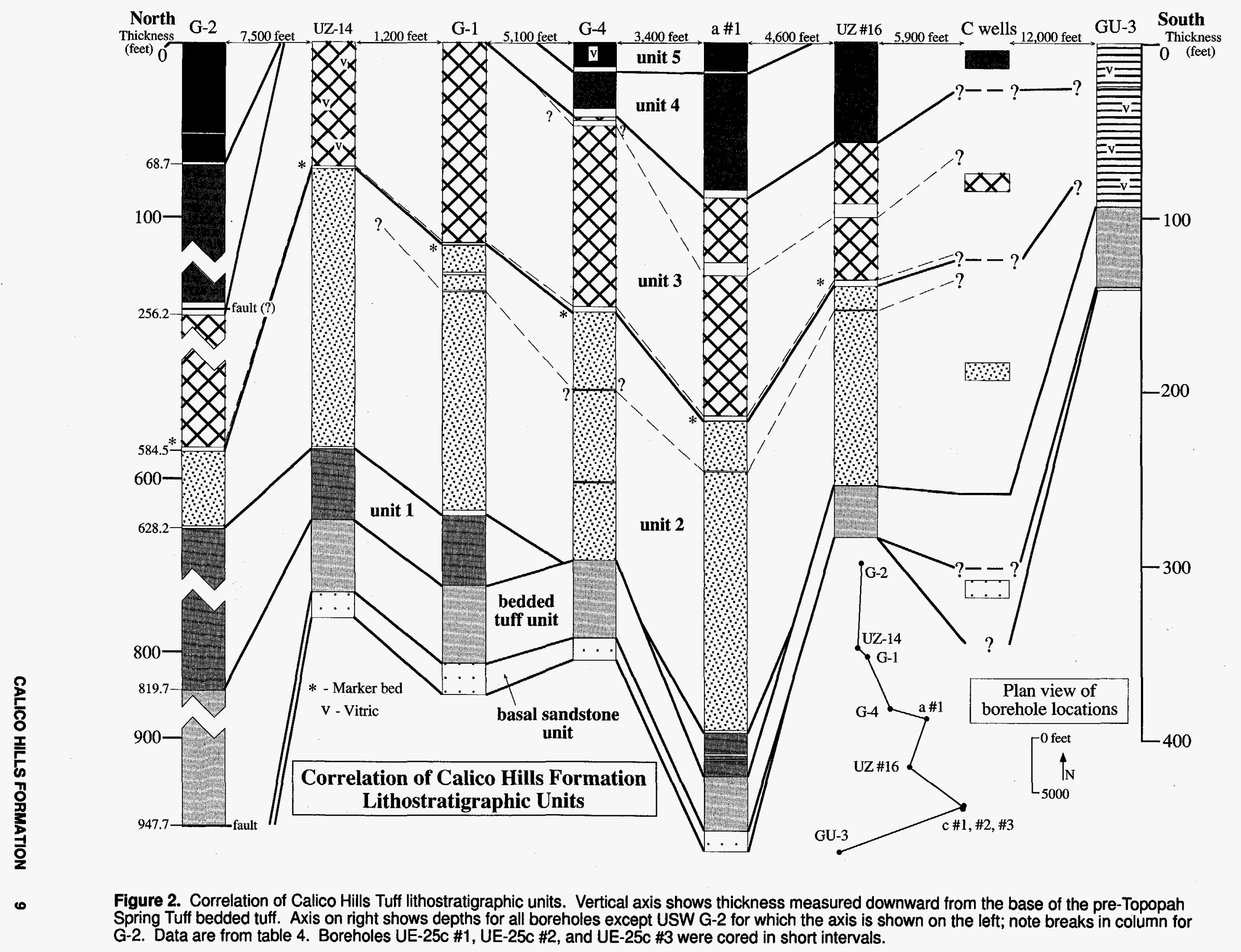


its recovered from borehole USW GU-3 as described above and likely has a similar genesis. The basal sandstone unit, the bedded tuff unit, and pyroclastic units 4 and 5 are recognized in zeolitically altered exposures at Prow Pass (Broxton and others, 1993).

Figure 3 is an isopach map of the composite apparent thickness of the Calico Hills Formation (the five pyroclastic units, bedded tuff, and basal sandstone). The figure utilizes data collected from cored boreholes (table 4) and is supplemented with thickness data from borehole logs produced from drill cuttings and observations of down-hole video. Apparent thickness distribution maps of individual lithostratigraphic units were not constructed due to a paucity of data. The formation thickness map defines a paleovalley on the eastern edge of Yucca Mountain. Four boreholes in the northern part of the paleovalley contain lava flows (from north to south: UE-25 WT \#6, UE-25 WT \#16, UE-25 WT \#18, UE-25 WT \#4; R.W. Spengler, 1993, written commun.), indicating that the flow of lava was topographically controlled in this area.

\section{Mineralogy, Geochemistry, and Alteration}

Numerous workers have studied the mineralogy, geochemistry and alteration of the Calico Hills Formation (table 2). Phenocryst data collected by petrographic analysis and elemental data collected by X-ray fluorescence analysis were evaluated by lithostratigraphic unit. Bulk mineralogical compositions determined by semi-quantitative X-ray diffraction analyses document the types of alteration products within the Calico Hills units.

\section{Phenocryst Mineralogy}

Some lithostratigraphic units in the Calico Hills Formation can be differentiated by their phenocryst mineralogy. Figure 4 shows the percentage of felsic phenocrysts (as reported in Broxton and others, 1989) in each of the five pyroclastic units and the bedded tuff unit. The petrographic data are limited; no samples were analyzed from the basal sandstone and only one sample studied from pyroclastic units 4 and 5 . Nevertheless, the felsic phenocryst content of the bedded tuff unit ( 13 to 24 percent) is markedly different from that of the pyroclastic units (less than 12 percent), and pyroclastic unit 1 ( 7 to 12 percent) is distinct from units 2 through 5 (less than 7 percent). Visual estimates of mafic silicate phenocryst abundance indicate that the basal sandstone unit contains significantly more biotite than the overlying pyroclastic units.
Figure 5 is a plot of the proportions of quartz $(\mathrm{Q})$, alkali feldspar $(\mathrm{K})$ and plagioclase $(\mathrm{P})$ (from Broxton and others, 1989) in the felsic phenocryst assemblage. The limited petrographic data define compositional fields that comprise the bedded tuff unit and pyroclastic unit 1 ; pyroclastic unit 2 ; and pyroclastic units 3,4 , and 5. Additional petrographic analyses are needed to determine if these three fields are robust.

\section{Geochemistry}

Elemental compositions determined by X-ray fluorescence analysis (Z.E. Peterman and others, 1994, written commun.) differentiate the basal sandstone unit, bedded tuff unit and the pyroclastic units. These data do not, however, distinguish the five pyroclastic units. Figure 6 illustrates the variable, but high Sr and low to moderate $\mathrm{Rb}$ concentrations of the basal sandstone that are distinct from the $\mathrm{Sr}$ and $\mathrm{Rb}$ concentrations of most pyroclastic samples ( 3 of 46 pyroclastic samples overlap other fields). Samples collected from the bedded tuff unit have intermediate $\mathrm{Sr}$ and $\mathrm{Rb}$ abundances. Figure 7 shows that samples of the basal sandstone have distinctly higher Ti than samples of the pyroclastic units. Pyroclastic unit 1 has variable Ti concentrations that overlap fields for the bedded tuff unit and pyroclastic units 2 through 5 .

\section{Alteration History}

Zeolite minerals are restricted to four stratigraphic intervals at Yucca Mountain including the Calico Hills Formation and upper Prow Pass Tuff, which compose zeolite interval II (Vaniman and others, 1984). X-ray diffraction analyses of core samples by Caporuscio and others (1982), Vaniman and others (1984), Bish and Vaniman (1985), and Bish and Chipera (1986), and of outcrop samples by Broxton and others (1993) show an abundance of authigenic zeolites in all units of the Calico Hills Formation. Pyroclastic units have extremely high clinoptilolite and mordenite contents (approximately 40 to 80 percent; Caporuscio and others, 1982; Vaniman and others, 1984; Bish and Vaniman, 1985; Bish and Chipera, 1986) that contrast with the somewhat lower zeolite content of the bedded tuffs and basal sandstone.

The distribution of zeolitic alteration within the five pyroclastic units is depicted in figure $8 \mathrm{~A}$ and within the bedded tuff and basal sandstone units in figure 8B. These figures illustrate that zeolite mineralization is pervasive in the northern part of Yucca Mountain (Caporuscio and others, 1982; Bish and Vaniman, 1985; Bish and Chipera, 1986; Broxton and others, 1993), but absent in southern locations (USW 


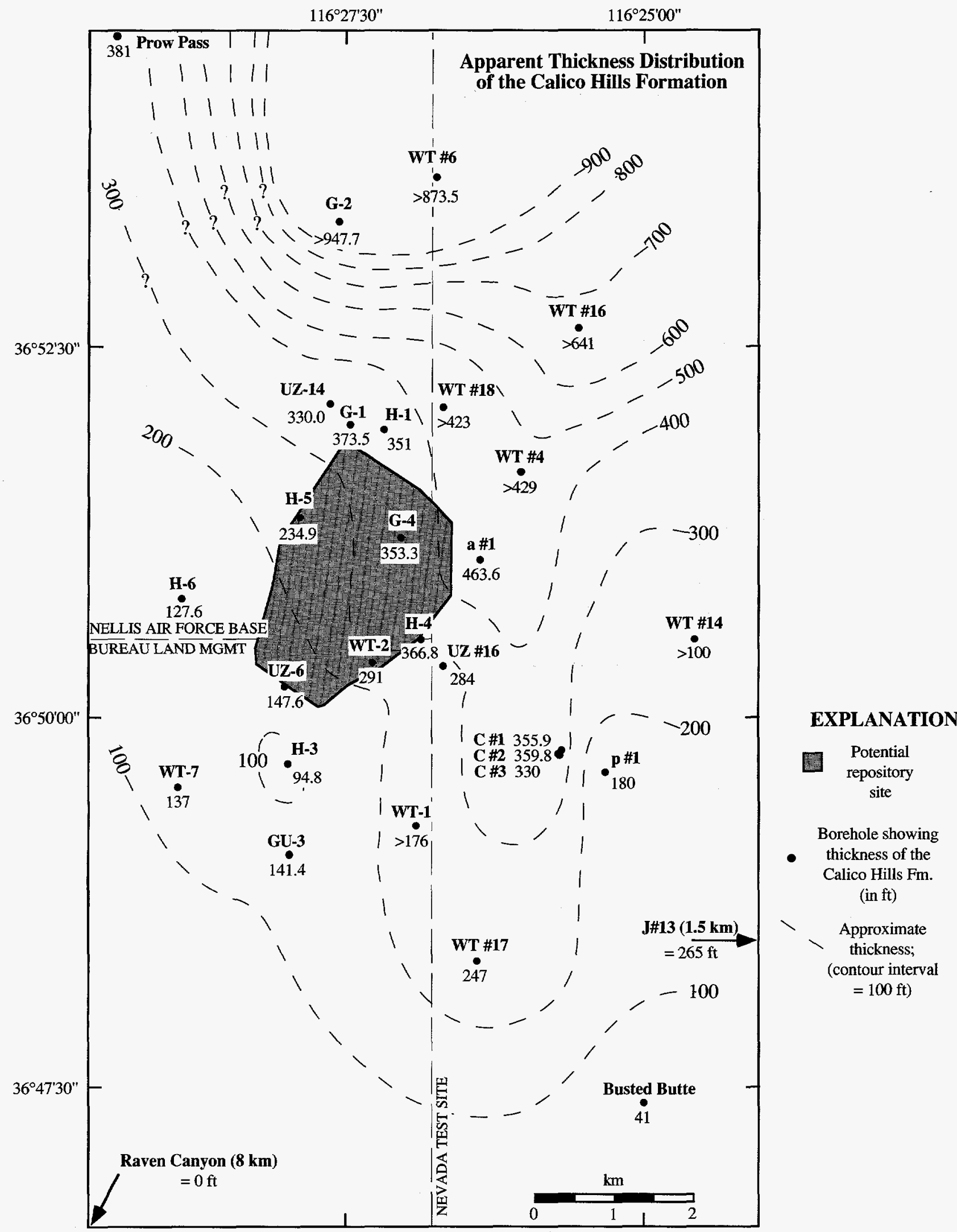

Figure 3. Thickness distribution of the Calico Hills Formation (including bedded tuff and basal sandstone units) constructed using apparent thickness data from table 4 and Bentley and others (1983), Craig and others (1983), Rush and others (1984), Thordarson and others (1984), Witfield and others (1984; 1993), Carr and others (1986b), Nelson and others (1991), Broxton and others (1993), Geldon (1993), Peterman and others (1993), and R.W. Spengler, written commun. (1993). 


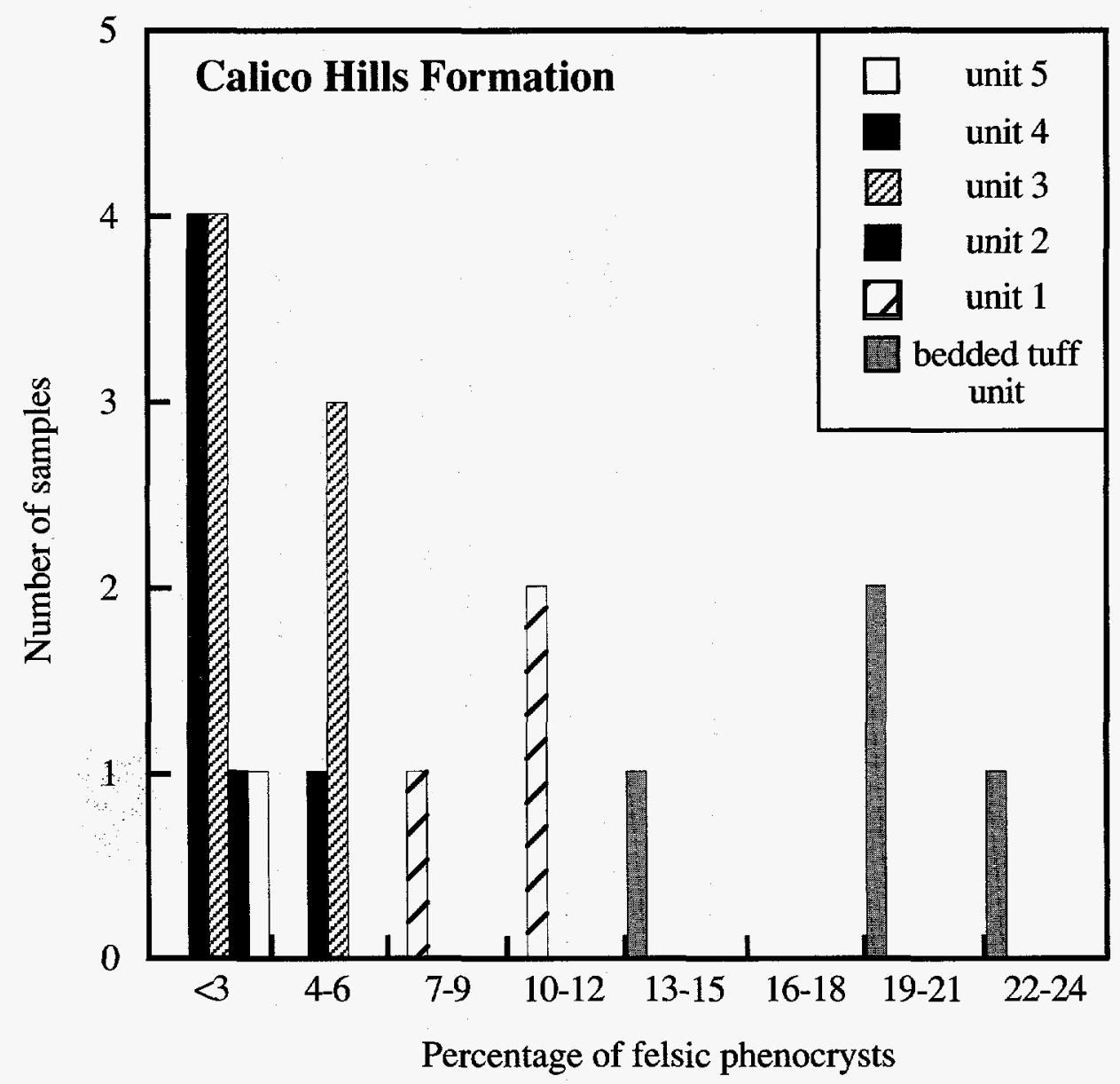

Figure 4. Content of felsic phenocrysts in the Calico Hills Formation plotted by lithostratigraphic unit. Data are from Broxton and others (1989). 


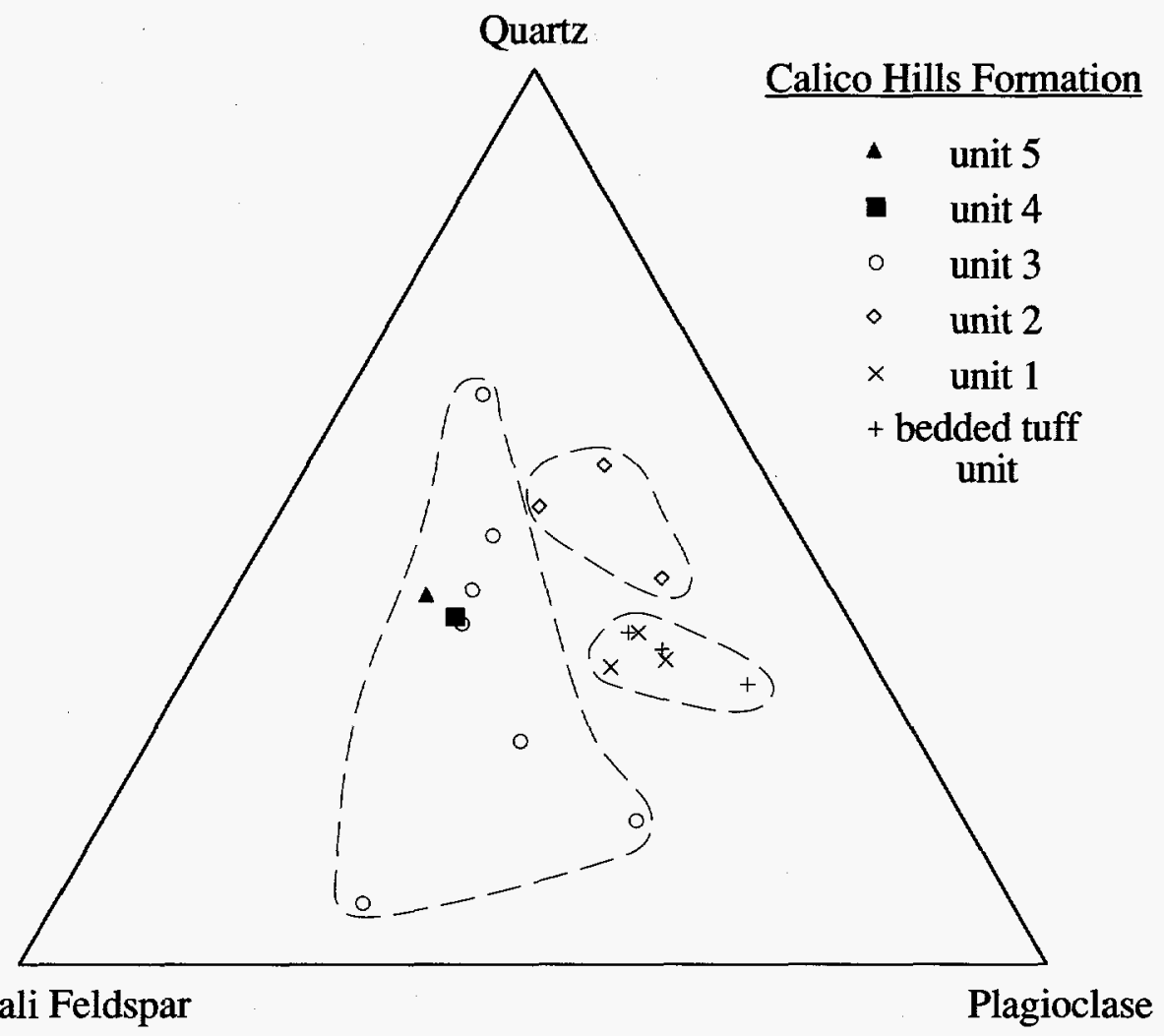

Alkali Feldspar

Plagioclase

Figure 5. Triangular plot of the proportions of quartz $(Q)$, alkali feldspar $(K)$ and plagioclase (P) phenocrysts in the felsic phenocryst assemblage of the Calico Hills Formation. Data are from Broxton and others (1989). 


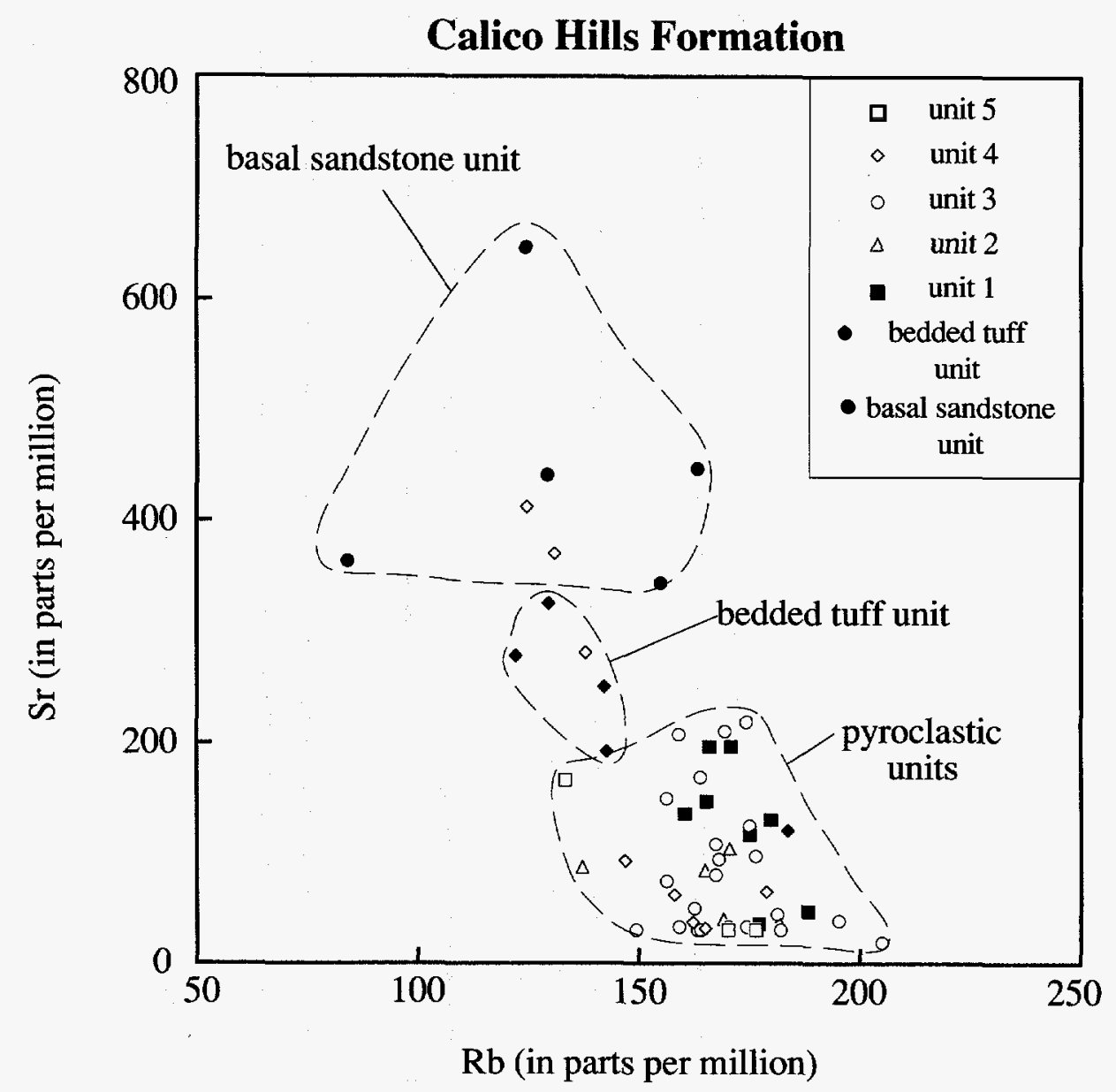

Figure 6. Strontium versus rubidium plotted by lithostratigraphic unit for the Calico Hills Formation. Data are from Z.E. Peterman and others, written commun. (1994). 


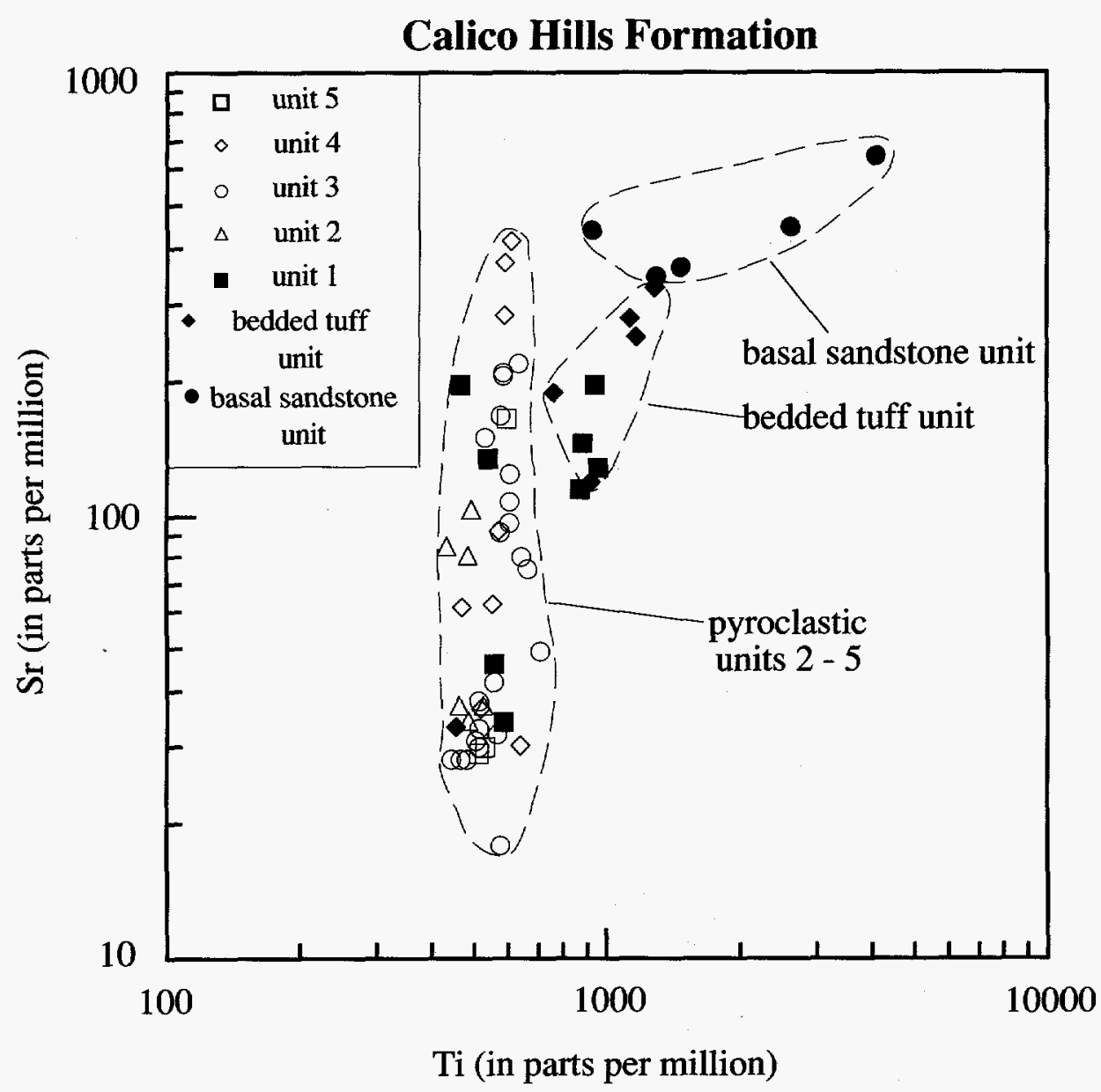

Figure 7. Strontium versus titanium plotted by lithostratigraphic unit for the Calico Hills Formation. Data are from Z.E. Peterman and others, written commun. (1994).

GU-3 and Busted Butte) where the Calico Hills Formation is vitric (Vaniman and others, 1984; Broxton and others, 1993). This distribution indicates that ground waters interacted extensively with the Calico Hills Formation in the northern part of the Yucca Mountain area (Vaniman and others, 1984). Differences in the amount of zeolites in the pyroclastic and bedded tuff units may be due to differences in their content of primary glass. Nevertheless, zeolites are more widely distributed in the bedded tuffs than in the pyroclastic units (fig. 8) suggesting slightly different alteration histories.

\section{Geophysical Signatures}

Geophysical logs from numerous boreholes that penetrate the Calico Hills Formation at Yucca Mountain are compiled in Nelson and others (1991), who noted that density, porosity, resistivity, and magnetic susceptibility logs are most useful for correlating the
Calico Hills Formation. Figure 9 shows that contacts between pyroclastic units cannot be distinguished by changes in geophysical character. However, the logs show distinct changes at the contact between the pyroclastic units (which have distinctively low measured values) and the bedded tuff unit, which is recognized by downward increasing density and magnetic susceptibility, decreasing porosity, and resistivity that generally increases then decreases (fig. 9). The basal sandstone unit is distinguished by downward decreasing density, resistivity and magnetic susceptibility, and increasing porosity (fig. 9).

The geophysical signatures of the Calico Hills Formation lithostratigraphic units primarily reflect their lithology and content of authigenic minerals [zeolites, smectite, alkali feldspar and quartz; (Nelson and others, 1991)]. The differing physical properties of nonwelded pyroclastic-flow material, crystal-rich fallout tephra and volcaniclastic sandstone likely explains the different density and porosity values of the pyro- 


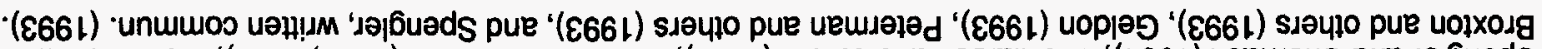

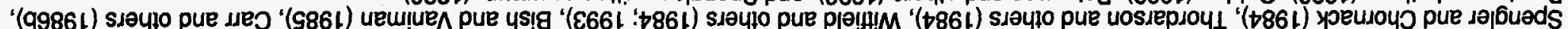

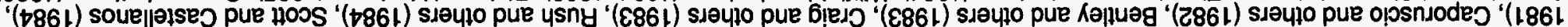

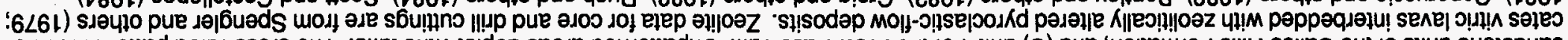

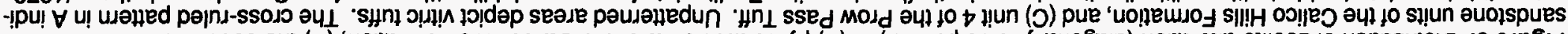

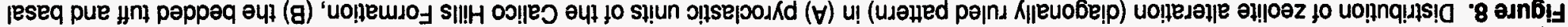

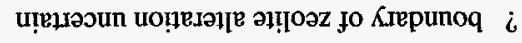

$$
\text { วฺ! }
$$

Krol!̣sodəI [eṭuə̧od

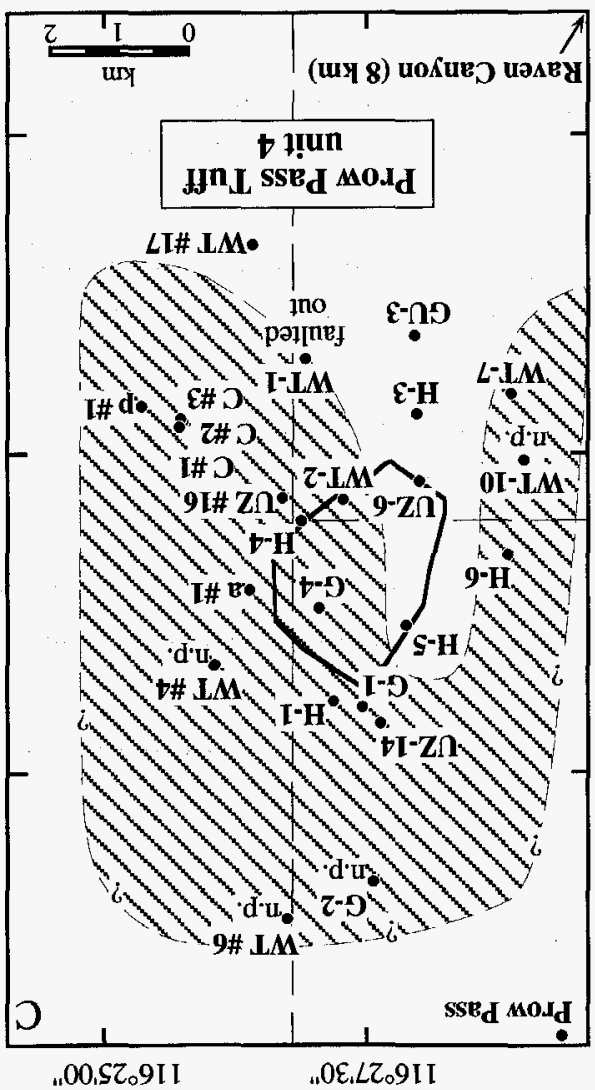

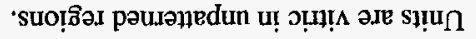

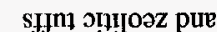

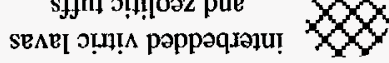

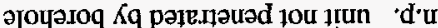

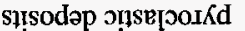

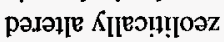

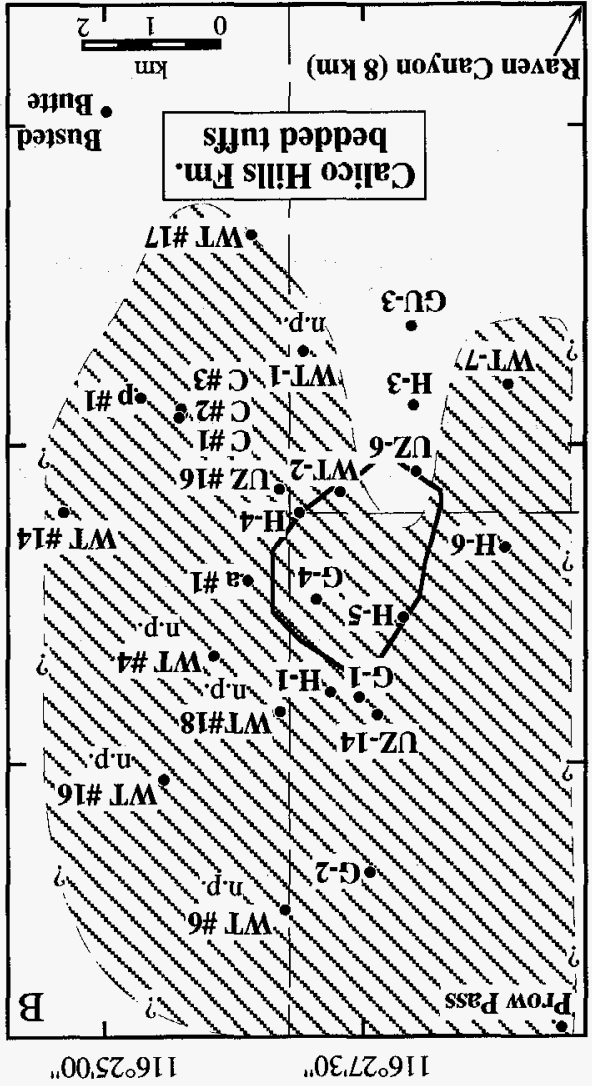




\section{Calico Hills Formation}

\section{USW G-1}

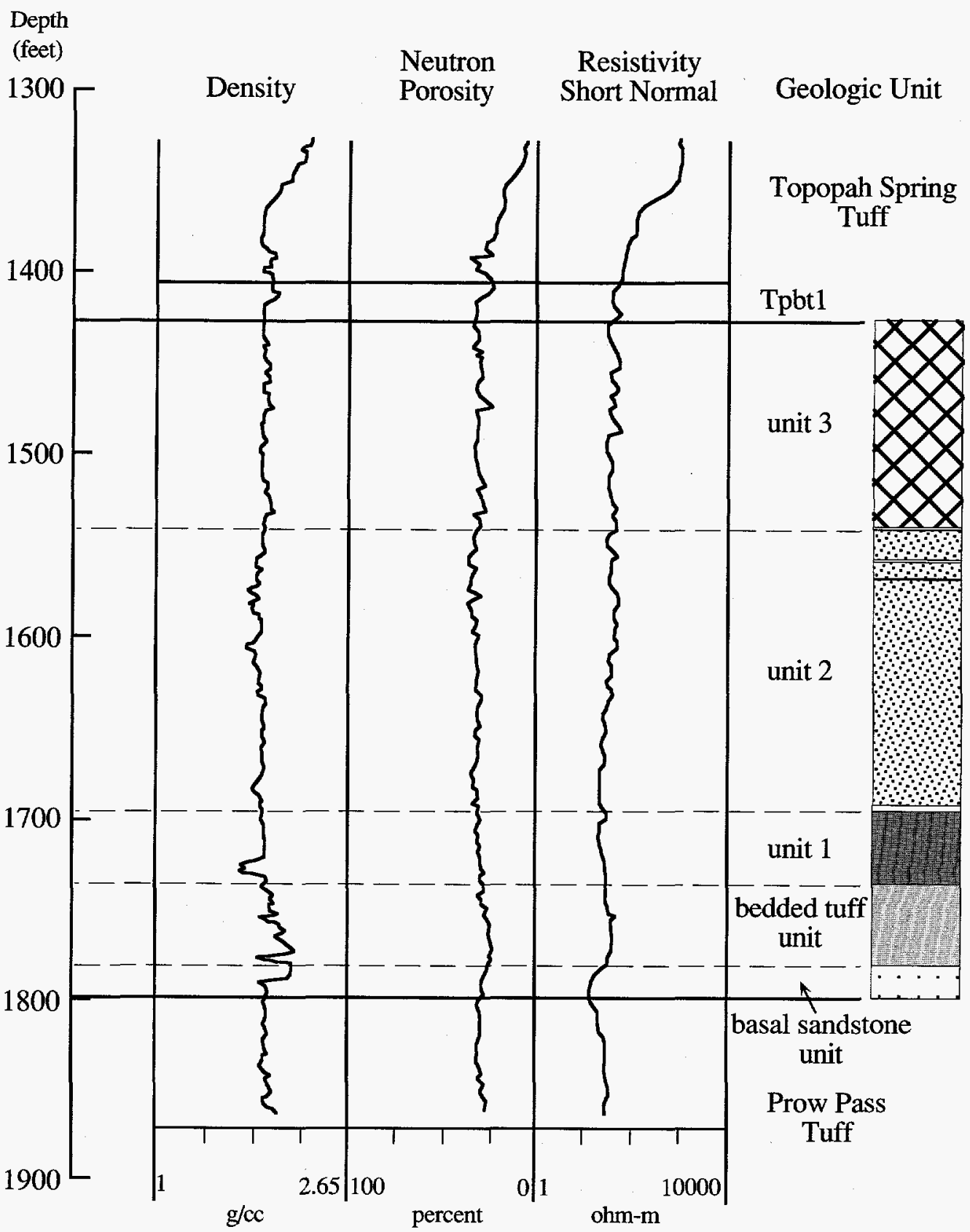

Figure 9A. Geophysical logs compared to the lithostratigrapic units of the Calico Hills Formation. (A) Borehole USW G-1, (B) Borehole USW G-4, and (C) Borehole UE-25a \#1. Geophysical logs and static water level are from Nelson and others (1991). 


\section{Calico Hills Formation \\ USW G-4}

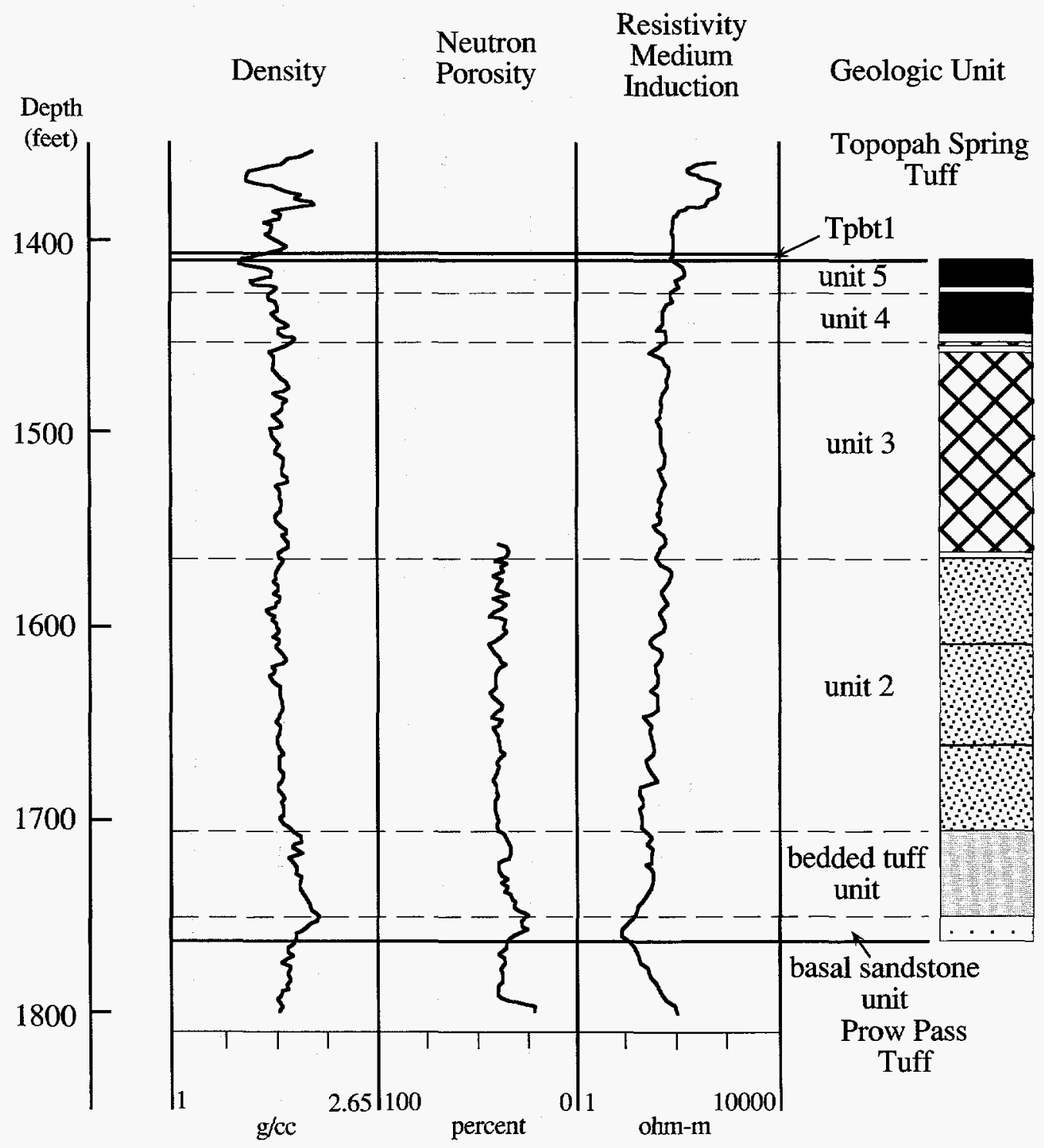

Figure 9B. Geophysical logs compared to the lithostratigrapic units of the Calico Hills Formation. (A) Borehole USW G-1, (B) Borehole USW G-4, and (C) Borehole UE-25a \#1. Geophysical logs and static water level are from Nelson and others (1991)--Continued. 


\section{Calico Hills Formation}

UE-25 a \#1

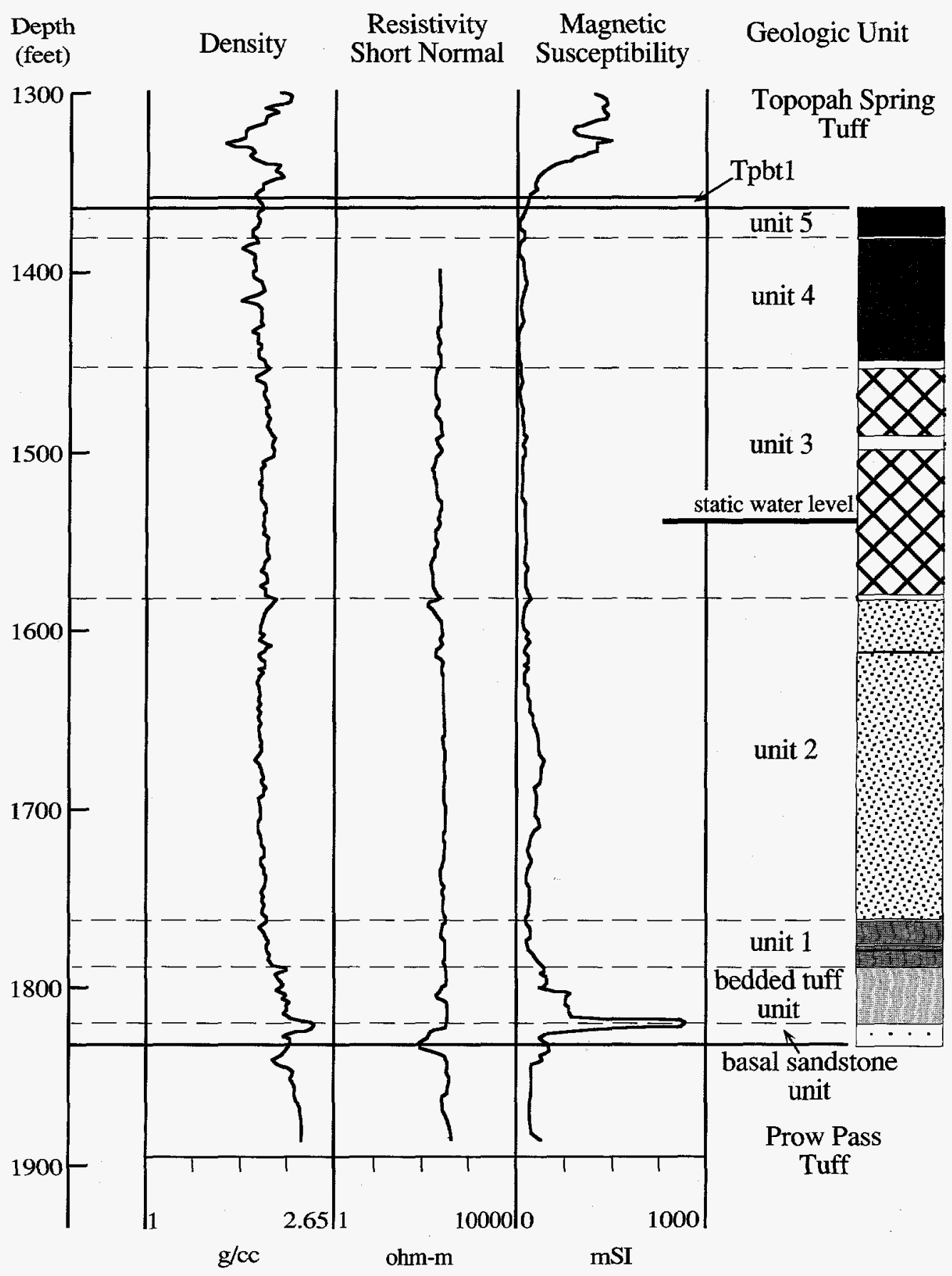

Figure 9C. Geophysical logs compared to the lithostratigrapic units of the Calico Hills Formation. (A) Borehole USW G-1, (B) Borehole USW G-4, and (C) Borehole UE-25a \#1. Geophysical logs and static water level are from Nelson and others (1991)--Continued. 


\section{Calico Hills Formation}

USW G-1

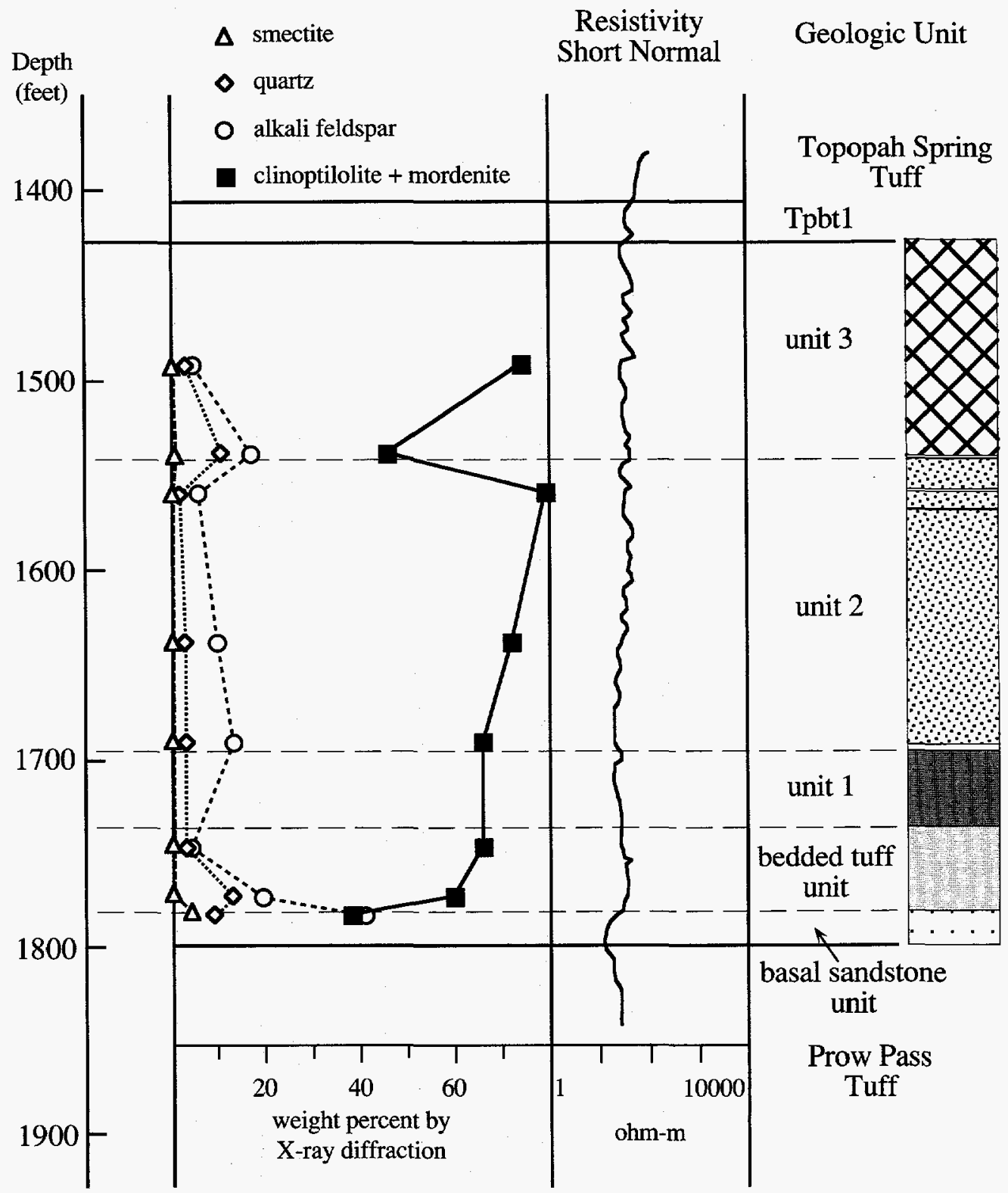

Figure 10A. Mineralogy determined by $X$-ray diffraction studies and electrical resistivity compared to the lithostratigraphic units of the Calico Hills Formation. (A) USW G-1, (B) USW G-4. X-ray diffraction data for USW G-1 are from Bish and Chipera (1986), and data for USW G-4 are from Bish and Vaniman (1985). Resistivity logs are from Nelson and others (1991). 


\section{Calico Hills Formation \\ USW G-4}

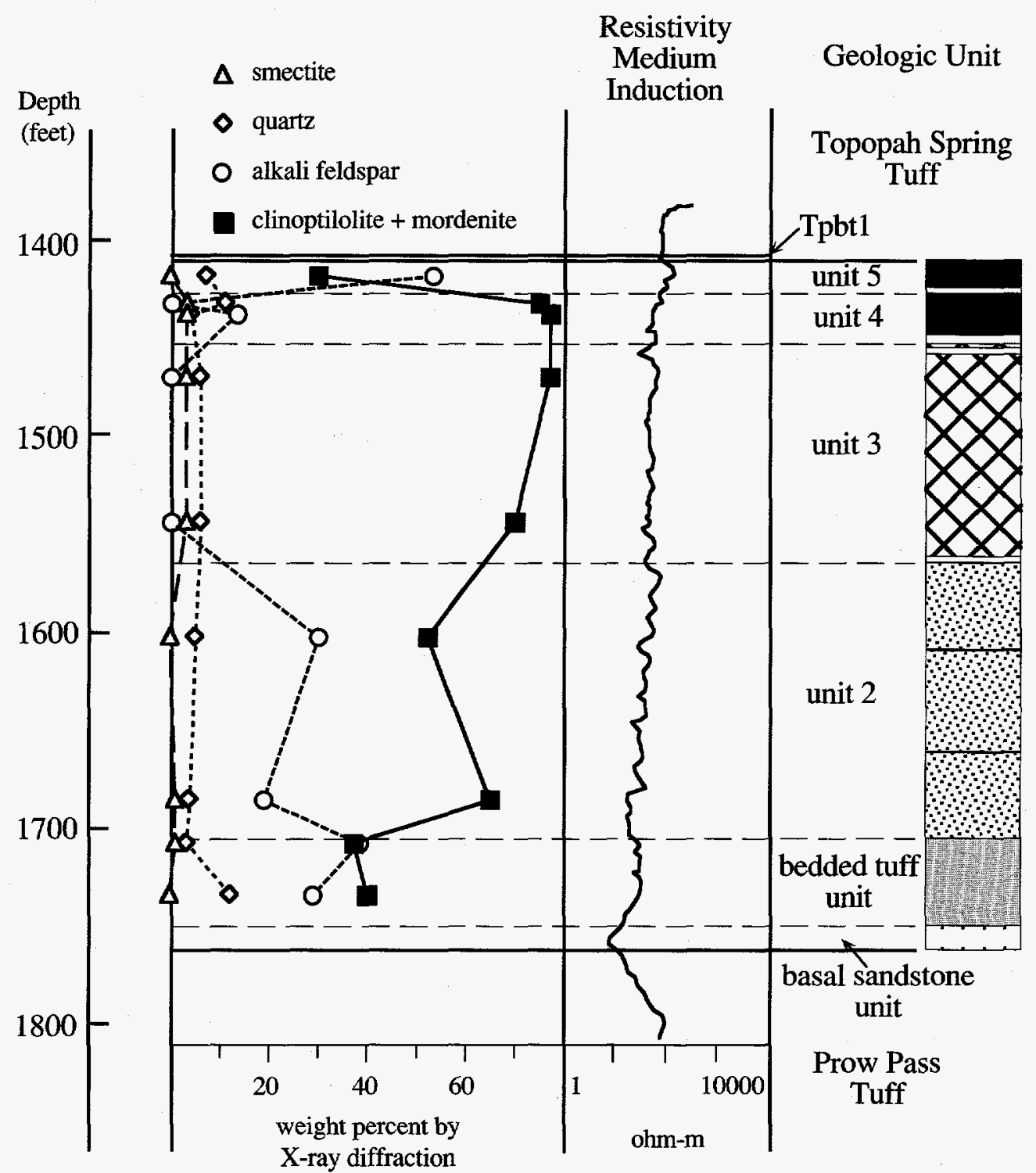

Figure 10B. Mineralogy determined by $\mathrm{X}$-ray diffraction studies and electrical resistivity compared to the lithostratigraphic units of the Calico Hills Formation. (A) USW G-1, (B) USW G-4. X-ray diffraction data for USW G-1 are from Bish and Chipera (1986), and data for USW G-4 are from Bish and Vaniman (1985). Resistivity logs are from Nelson and others (1991) --Continued. 
clastic units, bedded tuff unit and basal sandstone unit that allow their distinction. As shown in figure 10, the resistivity of the Calico Hills Formation varies in response to both zeolite content, which is higher in the pyroclastic units, and to alkali feldspar and quartz content (both authigenic and allogenic), which is higher in the bedded tuff and basal sandstone units.

\section{PROW PASS TUFF}

Four pyroclastic units and an underlying interval of bedded tuff compose the Prow Pass Tuff in the Yucca Mountain region. The pyroclastic units are given informal numerical designations that increase from the base of the formation upward: unit 1 is a sequence of nonwelded, pumiceous pyroclastic-flow deposits; unit 2 is a sequence of lithic-rich pyroclasticflow deposits; unit 3 is a welded pyroclastic-flow deposit that displays a compound cooling history; and unit 4 is a sequence of pyroxene-rich pyroclastic-flow deposits. This section summarizes the lithostratigraphy of the Prow Pass Tuff in the Yucca Mountain area, examines vertical and lateral variations in its lithologic, geochemical, and geophysical properties, and defines criteria to identify the lithostratigraphic units described herein.

\section{Lithostratigraphic Unit Descriptions}

Outlined below are the salient features of the Prow Pass Tuff lithostratigraphic units. Appendixes 3 and 4 provide detailed descriptions of lithologic contacts and lithostratigraphic units. Table 5 summarizes the lithostratigraphy of the Prow Pass Tuff, and table 6 gives the depths-to-unit and subunit contacts in cored boreholes.

Unit 4 contains three subunits, each composed of one or more pyroclastic-flow deposits, distinguished by the size and amount of included pumice clasts. Unit 3 includes six subunits defined by changes in the degree of welding or the intensity of vapor-phase alteration. Locally preserved, interbedded ash-fall horizons and abrupt variations in the amounts and sizes of pumice and lithic clasts mark flow boundaries within unit 3.

Unit 2 is a sequence of three or more pyroclastic-flow deposits that have not been subdivided due to an absence of distinguishing criteria. Unit 1 contains three pyroclastic-flow deposits that can be identified by their content of lithic clasts; the upper and lower subunits may not be distinguished where the middle subunit is absent.

Units of the Prow Pass Tuff contain phenocrysts of sanidine and plagioclase in subequal amounts, sub- ordinate quartz, minor biotite, orthopyroxene (typically altered), and Fe-Ti oxides, and accessory hornblende, apatite, zircon, and allanite (Broxton and others, 1989). Although unit 4 contains more pyroxene (by visual estimate) than other Prow Pass Tuff units, the ratio of felsic to mafic phenocrysts commonly exceeds 20 in all units (Broxton and others, 1989). Lithic clasts include siltstone, porphyritic felsic lava, phenocryst-poor felsic lava, biotite- and feldspar-bearing tuff, and biotite-rich porphyry. Lithic clasts of scoriaceous glass occur in unit 1 .

\section{Unit 4}

The nonwelded deposits of unit 4 are altered to zeolite and clay minerals throughout most of the Yucca Mountain region, but are vitric in borehole USW GU3 and in exposures at Raven Canyon and Busted Butte (Broxton and others, 1993). They have an aggregate thickness that varies from 12.6 to 67.1 feet in cored boreholes at Yucca Mountain (table 6). Subunit contacts are marked by abrupt changes in the sizes and amounts of pumice clasts which grade over intervals of less than 1 foot. Several pyroclastic-flow deposits, separated by thin (less than $3 \mathrm{~mm}$ ), ash-rich horizons, are present locally within the middle subunit (in borehole USW G-1). Multiple flows are not recognized in other subunits, although exposures of the lower subunit at Raven Canyon contain irregular accumulations of pumice, characteristic of the distal edges of pumiceous pyroclastic-flow deposits (Rowley and others, 1981).

The pinkish matrix of the upper subunit (locally it occurs as a mottled mix with light olive gray) darkens in the upper few feet where alteration is more intense. Shard textures are absent in this subunit. Where altered, the matrix of the middle subunit is light gray to very pale orange with variably preserved shard textures; where vitric, it is pale orange-brown with colorless glass shards. Altered samples of the lower subunit have variable matrix colors that include light shades of gray, orange, or pink. Vitric samples of the lower subunit contain colorless glass shards and have matrix colors that vary from very pale orange to orange-pink.

The size and amount of pumice clasts can be used to distinguish the subunits of unit 4. The upper subunit typically contains nondeformed, very small (less than $5 \mathrm{~mm}$ ), sparse ( 3 to 10 percent) pumice clasts. In contrast, the middle subunit contains pumice clasts that are non- to slightly deformed, small ( 3 to $12 \mathrm{~mm}$ ), and moderately abundant (10 to 20 percent), whereas the lower subunit contains abundant ( 15 to 25 percent), large ( 10 to $40 \mathrm{~mm}$ ), nondeformed pumice clasts. Unique to the lower and middle subunits of unit 4 are pumice clasts with large (up to $3 \mathrm{~mm}$ ) plagio- 
Table 5. Brief description of lithostratigraphic units of the Prow Pass Tuff

Unit 4 - Pyroxene-rich pyroclastic-flow deposits

Upper subunit - massive ash; pumice-poor; vitric, devitrified, or altered to clay and/or zeolite minerals.

Middle subunit - 1 to 4 flow units; pumice clasts are from 3 to $12 \mathrm{~mm}$; vitric, devitrified, or altered to clay and/or zeolite minerals.

Lower subunit - 1 to 2 flow units; pumice clasts are from 10 to $40 \mathrm{~mm}$; pyroxene common in pumice clasts; vitric, devitrified, or altered to clay and/or zeolite minerals. The basal contact is a sharp break below which is intensely vapor-phase altered and devitrified tuff.

Unit 3 - Welded pyroclastic-flow deposit

Strongly vapor-phase altered subunit - devitrified; intense vapor-phase alteration; corroded, nondeformed pumice clasts.

Upper non- to partially welded subunit - devitrified; minor vapor-phase alteration; nondeformed pumice clasts.

Upper moderately welded subunit - devitrified; minor vapor-phase alteration; deformed (elongated) pumice clasts.

Middle non- to partially welded subunit - devitrified; minor vapor-phase alteration; nondeformed pumice clasts.

Lower moderately welded subunit - devitrified; minor vapor-phase alteration; deformed (elongated) pumice clasts; locally oxidized and argillically altered.

Lower non- to partially welded subunit - devitrified; minor vapor-phase alteration; nondeformed pumice clasts; oxidized and locally altered to clay and/or zeolite minerals. The basal contact is a locally preserved ash-fall deposit that separates an overlying lithic-poor pyroclastic-flow deposit from an underlying lithic-rich pyroclastic-flow deposit.

Unit 2 - Lithic-rich pyroclastic-flow deposits

1 to 3 flow deposits; 3 to 7 percent lithic clasts; nondeformed pumice clasts (locally elongated); devitrified; pervasively altered to zeolite and clay minerals. The basal contact is a locally preserved ash-fall deposit that separates an overlying pyroclastic-flow deposit with moderately sized pumice clasts and abundant lithic clasts from an underlying pyroclastic-flow deposit with larger pumice clasts and fewer lithic clasts.

Unit 1 - Pumiceous pyroclastic-flow deposits

Upper subunit - devitrified; pumice clasts are from 10 to $40 \mathrm{~mm}$ and nondeformed; 1 to 3 percent lithic clasts; pervasively altered to zeolite minerals.

Middle subunit - devitrified; pumice clasts are from 5 to $30 \mathrm{~mm}$ and nondeformed; 3 to 5 percent lithic clasts; pervasively altered to zeolite minerals.

Lower subunit - devitrified; pumice clasts are from 5 to $25 \mathrm{~mm}$ and nondeformed; 1 to 3 percent lithic clasts; pervasively altered to zeolite minerals. The basal contact is depositional and separates an overlying pyroclastic-flow deposit from an underlying deposit of laminated ash.

\section{Bedded tuffs unit}

Laminated ash subunit - thinly laminated fine-grained deposits that locally exhibit low-angle cross-stratification.

Pumiceous tuffs subunit - A series of one to five locally preserved, nonwelded, variably altered deposits: upper pumiceous tuff, reworked, pumice content of 20 to 70 percent, rare biotite; upper pyroclastic-flow deposit, 5 to 7 percent phenocrysts including subordinate biotite, pyroxene pseudomorphs or hornblende, 3 to 5 percent lithic clasts; lower pyroclastic-flow deposit, 7 to 10 percent phenocrysts including abundant biotite, 10 to 15 percent lithic clasts; lower pumiceous tuff, reworked, pumice content of 25 to 80 percent, abundant biotite; breccia, clasts of Bullfrog Tuff and locally other felsic volcanic lithologies. The Bullfrog Tuff is recognized by abundant biotite and a higher percentage of quartz in the felsic phenocryst assemblage; it varies from nonwelded to moderately welded at the contact. 
Table 6. Depths to Prow Pass Tuff contacts in cored boreholes

[Refer to figure I for borehole locations; n.p., unit is not present; depths in feet]

\begin{tabular}{|c|c|c|c|c|c|c|c|}
\hline & USW G-2 & USW UZ-14 & USW G-1 & USW G-4 & UE-25a \#1 & UE-25 UZ \#16 & USW GU-3 \\
\hline \multicolumn{8}{|l|}{ Calico Hills Formation } \\
\hline & $2,704.7$ & $1,750.2$ & $1,799.0$ & $1,762.7$ & $1,832.2$ & $1,485.1$ & $1,553.9$ \\
\hline Prow Pass Tuff & & & & & & & \\
\hline \multicolumn{8}{|c|}{ Unit 4 - Pyroxene-rich unit } \\
\hline Upper subunit & n.p. & $1,761.5$ & $1,814.3$ & $1,785.0$ & $1,835.0$ & n.p. & n.p. \\
\hline Middle subunit & n.p. & 1,768 & $1,832.0$ & $1,790.7$ & $1,837.6$ & $1,487.8$ & $1,559.5$ \\
\hline Lower subunit & n.p. & $1,814.9$ & $1,862.5$ & $1,793.6$ & $1,845.1$ & $1,497.7$ & $1,601.0$ \\
\hline \multicolumn{8}{|c|}{ Unit 3 - Welded pyroclastic-flow deposit } \\
\hline Strongly vapor-phase altered & n.p. & n.p. & $1,866.0$ & $1,796.1$ & 1,851 & $1,500.6$ & 1,604 \\
\hline Upper non- to partially welded & n.p. & $1,826.0$ & $1,885.0$ & $1,800.4$ & 1,860 & 1,523 & $1,641.0$ \\
\hline Upper moderately welded & $2,772.9$ & 1,841 & $1,922.0$ & $1,820.5$ & 1,877 & 1,546 & $1,662.0$ \\
\hline $\begin{array}{l}\text { Middle non- to partially } \\
\text { welded }\end{array}$ & $2,777.0$ & 1,850 & $1,935.0$ & 1,830 & 1,925 & 1,571 & $1,669.0$ \\
\hline Lower moderately welded & 2,956 & $1,884.8$ & $1,978.0$ & $1,951.4$ & 2,009 & 1,648 & $1,744.0$ \\
\hline Lower non- to partially welded & $2,963.7$ & $1,896.3$ & 1,991 & $1,954.6$ & $2,016.1$ & $1,677.9$ & $1,754.5$ \\
\hline \multicolumn{8}{|c|}{ Unit 2 - Lithic-rich pyroclastic-flow deposit } \\
\hline & $3,048.9$ & $2,007.3$ & $2,073.9$ & $2,050.3$ & $2,105.8$ & $1,686.2$ & $1,765.3$ \\
\hline & & & & & & Total depth & \\
\hline \multicolumn{8}{|c|}{ Unit 1 - Pumiceous pyroclastic-fiow deposit } \\
\hline Upper flow unit & $3,156.8$ & $2,046.6$ & $2,154.9$ & $2,192.6$ & 2,277 & & $1,816.0$ \\
\hline Middle flow unit & $3,246.5$ & n.p. & n.p. & $2,229.5$ & $2,331.4$ & & $1,917.7$ \\
\hline Lower flow unit & n.p. & n.p. & n.p. & $2,238.0$ & n.p. & & $1,992.3$ \\
\hline \multicolumn{8}{|c|}{ Pre-Prow Pass bedded tuff } \\
\hline Laminated ash & $3,251.1$ & $2,048.4$ & $2,156.7$ & $2,239.7$ & $2,333.0$ & & $1,992.9$ \\
\hline Reworked(?) deposits & $3,281.9$ & $2,072.1$ & $2,173.2$ & $2,245.7$ & $2,333.5$ & & $1,998.7$ \\
\hline Bullfrog Tuff & & & & & & & \\
\hline
\end{tabular}


clase crystals and common pyroxene. Vitric pumice clasts are grayish orange to pale yellowish brown; altered or devitrified pumice clasts are white, or shades of orange, pink, and red.

Phenocrysts comprise from 10 to 15 percent of the lower and middle subunits by visual estimate, but decrease upward through the upper subunit (from 5 to 7 percent near the basal contact to 2 to 4 percent near the upper contact). The limited modal data compiled in Broxton and others (1989) suggest that phenocryst abundance may decrease upward through unit 4 (fig. 11). Lithic clasts, predominantly siltstone with subordinate volcanic lithologies, are visually estimated at 1 to 2 percent in all subunits.

\section{Unit 3}

The welded pyroclastic-flow deposits of unit 3 exhibits subtle variations consistent with a compound cooling history. Measurements of pumice elongation in boreholes USW G-2 and UE-25 UZ\#16 illustrate that a zone of less deformed pumice clasts separates two moderately welded subunits (fig. 12). The cooling break defined by pumice clasts between 10 and $30 \mathrm{~mm}$ (long dimension) can be identified visually in core, but pervasive devitrification and local alteration of the tuff matrix obscures textural evidence that could help to further clarify cooling history. Overlying and associated with the upper cooling zone is a region of intensively altered rock consisting of coarse-grained vaporphase minerals (the upper strongly vapor-phase altered subunit). Coarse-grained aggregates of vapor-phase minerals also are observed in pumice clasts in the upper part of the lower moderately welded subunit in some boreholes (USW G-1 from 1,935 to $1,960 \mathrm{ft}$ depth) and indicate that a similar zone of vapor-phase alteration is associated with the lower cooling zone. However, subsequent alteration obscures vapor-phase textures in samples of the lower welding zone from other boreholes. Importantly, it may be impossible to distinguish either the three non- to partially welded subzones from one another, or the upper and lower moderately welded subzones in samples lacking stratigraphic context.

Unit 3 has an aggregate thickness that varies from 128.5 to greater than $259.0 \mathrm{ft}$ in cored boreholes at Yucca Mountain (table 6), the thickest portion of which is the lower moderately welded subunit. Multiple flow deposits, either separated by locally preserved, thin (typically less than $10 \mathrm{~mm}$ thickness), ash-fall horizons or defined by abrupt variations in the amounts and sizes of pumice and lithic clasts, compose unit 3. Although two or three flow deposits are identified in most boreholes, they have not been correlated due to a lack of distinguishing characteristics. A depositional break has not been identified between the cooling zones.

Devitrification and local vapor-phase alteration of the tuff matrix have destroyed shard textures throughout most of unit 3 . The matrix typically is light gray or pale brown in the strongly vapor-phase altered subunit, light shades of gray, orange, brown, or red in the three non- to partially welded subunits, and variable tints of gray, brown, or red in the upper and lower moderately welded subunits. Although the matrix color of any given subunit varies as a function of oxidation, alteration, welding, and secondary crystallization, the lower moderately welded subunit is either darker or more red than other subunits. Alteration and oxidation of the tuff matrix within the lower part of the lower moderately welded subunit and in the lower non- to partly welded subunit impart a distinctive, mottled texture to the reddish rock created by white spots ( 5 to $15 \mathrm{~mm}$ diameter) that enclose tiny (mm-sized), siltstone clasts with moderate orange-pink, fuzzy rims. This texture is useful for distinguishing the lower moderately welded subzone where stratigraphic position is poorly constrained as in borehole UE-25c \#2 from 1,814 to $1,824 \mathrm{ft}$.

Variably deformed pumice clasts, in shades of pink, brown, or orange, are devitrified or replaced by vapor-phase minerals, and are corroded in the strongly vapor-phase altered subunit. They compose from 10 to 20 percent of the unit by visual estimate. Most pumice clasts contain sparse to rare phenocrysts; however, distinctive pale red, biotite-rich pumice clasts compose a few percent of the pumice population.

Phenocrysts constitute from 7 to 12 percent of unit 3 (Broxton and others, 1989). Variations in phenocryst content do not correspond to observed depositional or welding boundaries. Lithic clasts of siltstone predominate those of volcanic lithologies in all subunits. Visual estimates of lithic clast content, which vary from 1 to 4 percent (most commonly from 1 to 2 percent), do not correspond to observed depositional or welding boundaries.

\section{Unit 2}

The nonwelded- to partially welded deposits of unit 2 have an aggregate thickness that varies from 10.8 to 111.0 feet in the cored boreholes at Yucca Mountain (table 6); it is absent in exposures at Raven Canyon. Although locally preserved ash horizons and abrupt changes in the amounts and sizes of pumice and lithic clasts indicate that at least three flow deposits occur in most boreholes, unit 2 has not been subdivided because distinguishing criteria are lacking. Grain size variations that occur in the upper part of unit 2 in borehole 

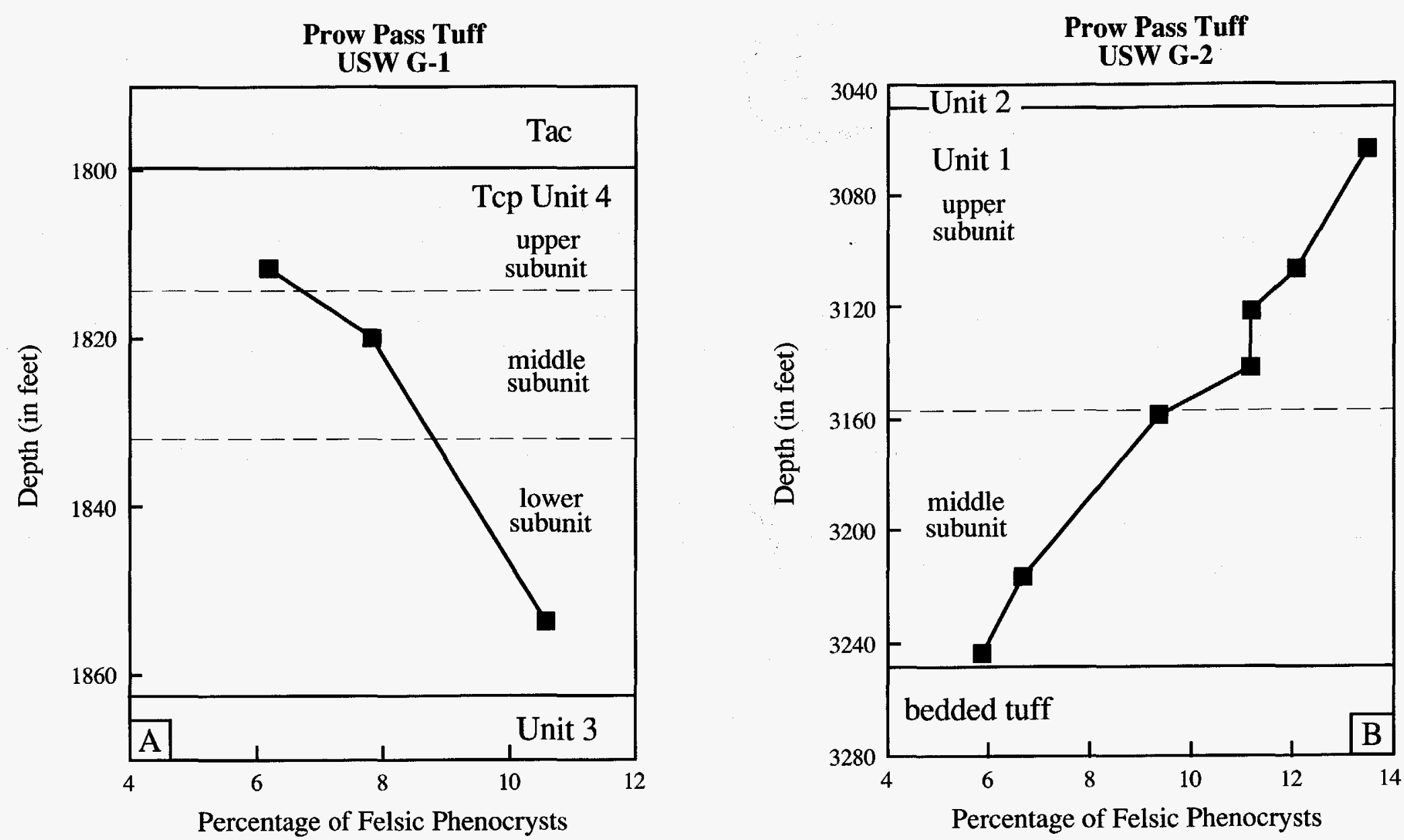

Figure 11. Percentage of felsic phenocrysts in the Prow Pass Tuff plotted versus depth. (A) Unit 4 in borehole USW G-1. (B) Unit 1 in borehole USW G-2. Data are from Broxton and others (1989). 

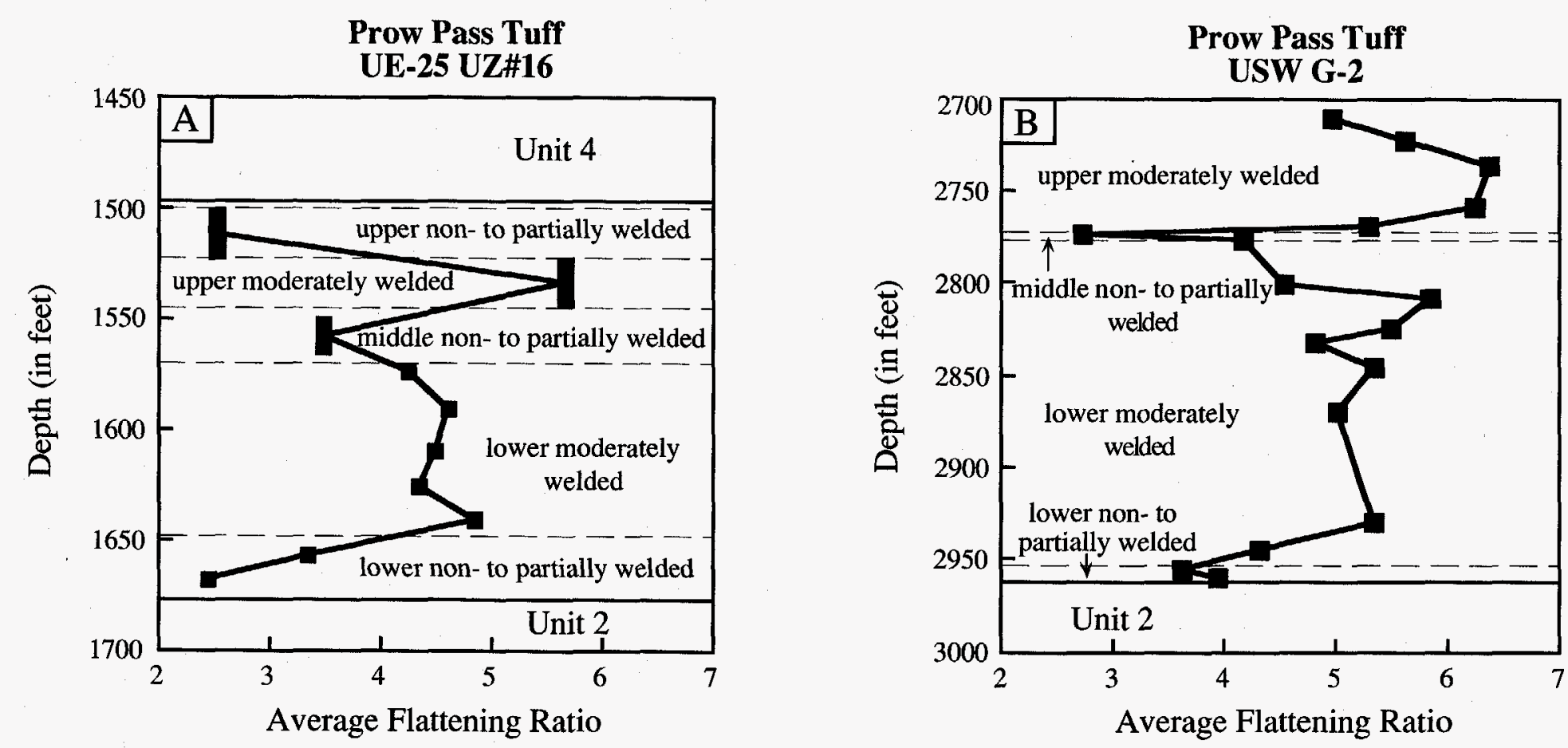

Figure 12. Average flattening ratios (length/width) for pumice clasts in Prow Pass Tuff unit 3 plotted versus depth. (A) Borehole

UE-25 UZ\#16; (B) Borehole USW G-2. Data are for pumice clasts of 10 to $30 \mathrm{~mm}$ diameter (long dimension). Flattening ratios are mean of 5 to 8 measurements; standard deviations of means typically are between 1 and 2 . 
USW G-1 may indicate intraflow shearing (Fisher and Schmincke, 1984), whereas the fine-grained base of the deposit in boreholes USW G-1 and USW G-2 may represent shearing along the substrate (Sparks, 1976). The similar sizes of pumice and lithic clasts and the presence of abundant phenocrysts impart a distinctive equigranular texture to unit 2.

Altered and devitrified matrix occurs in shades of red, pink, or gray, whereas zeolitically altered matrix is yellowish gray to light olive gray. Non- to slightly deformed pumice clasts comprise from 10 to 20 percent of the unit and may be devitrified or altered to vapor-phase minerals, clay or zeolite. Phenocrysts compose from 10 to 15 percent of the unit by visual estimate. Lithic clasts, predominantly siltstone with subordinate volcanic lithologies, constitute from 3 to 7 percent of the rock. Lithic clasts are scattered throughout the tuff matrix or concentrated in subvertical structures or irregular pods.

\section{Unit 1}

The non- to partially welded pyroclastic-flow deposits of unit 1 are altered to zeolite minerals in all boreholes examined from Yucca Mountain, but they remain vitric or devitrified in exposures at Raven Canyon. They have an aggregate thickness that varies from 82.8 to 227.0 feet in cored boreholes (table 6). Locally preserved ash-fall horizons separate three subunits that can be distinguished by their lithic clast contents. Abrupt variations in the sizes and amounts of pumice and lithic clasts define possible flow-unit boundaries within the subunits.

The three subunits are generally similar with a zeolitically altered matrix that occurs in shades of orange, brown, pink, yellow, or green. Vitric matrix is light gray to pink with colorless glass shards. Non- to slightly deformed pumice clasts, which are characteristically large, compose from 15 to 25 percent of the unit. Pumice clasts altered to zeolite minerals are shades of brown, orange, yellow, green, or gray, whereas vitric pumice clasts are gray, white or pale orange. Phenocrysts constitute from 7 to 12 percent of each subunit. Lithic clasts compose from 1 to 3 percent of the upper subunit, from 3 to 5 percent of the middle subunit, and from 2 to 3 percent of the lower subunit. Lithic clasts of siltstone predominate volcanic lithologies in the upper and lower subunits, but they occur in subequal amounts in the middle subunit.

\section{Bedded Tuff Unit}

This variable package of nonwelded, altered tuffaceous deposits has an aggregate thickness of 2.1 to
35.4 feet in the cored boreholes at Yucca Mountain (table 6). Contacts are either depositional and sharp or gradational over short intervals. The most conspicuous and widespread subunit is a laminated ash deposit that underlies the Prow Pass Tuff. It is typically very pale orange, extremely fine grained, and locally contains low-angle cross laminations. Underlying the laminated ash is a pumiceous tuff that may be a reworked fall deposit, two pyroclastic-flow deposits separated by a fine ash, and a lower pumiceous tuff that also may be a reworked fallout. One or more of these subunits are absent in most locations. The upper pumiceous tuff and upper pyroclastic-flow deposit contain phenocrysts of sanidine, plagioclase, and quartz, with subordinate biotite, pseudomorphs of pyroxene, Fe-Ti oxides, and rare hornblende. The lower pyroclastic-flow deposit and lower pumiceous tuff contain more abundant biotite and apparently lack pyroxene and hornblende. A thin (less than 2 feet), basal breccia containing angular clasts of Bullfrog Tuff and, locally, other volcanic lithologies occur in several locations.

\section{Lateral Distribution and Regional Correlation}

The distribution of the Prow Pass Tuff in the Yucca Mountain region is shown in figure 13. The composite apparent thickness of the Prow Pass Tuff pyroclastic units forms a south-trending lobe that coincides approximately with the western boundary of the Nevada Test Site. This interpretation is consistent with the distributions shown by Carr and others (1986a) for the Prow Pass Tuff and other formations of the Crater Flat Group.

Lithostratigraphic units and subunits of the Prow Pass Tuff can be correlated through the cored intervals of boreholes in the Yucca Mountain region (fig. 14), which emphasizes the lateral continuity of the lithostratigraphic units defined herein. Figure 14 also illustrates the thickness variations of individual units. Noteworthy are the variable thickness of unit 1 , the apparent southward thinning of unit 2 , the continuity of the welding and crystallization subunits of unit 3 , and the apparent eastward thinning of unit 4 (see fig. 13 for borehole locations). Lithostratigraphic relations within unit 3 in borehole USW G-2 indicate that the middle non- to partially welded subunit may pinch out northward as the unit thickens (fig. 12); this would produce the appearance of a single cooling unit.

Reconnaissance observations of Prow Pass Tuff exposures at Raven Canyon and in Prow Pass support conclusions drawn from the borehole studies and illuminate aspects of the lateral distribution of the Prow Pass Formation. Units 1, 3, and 4 are present at 


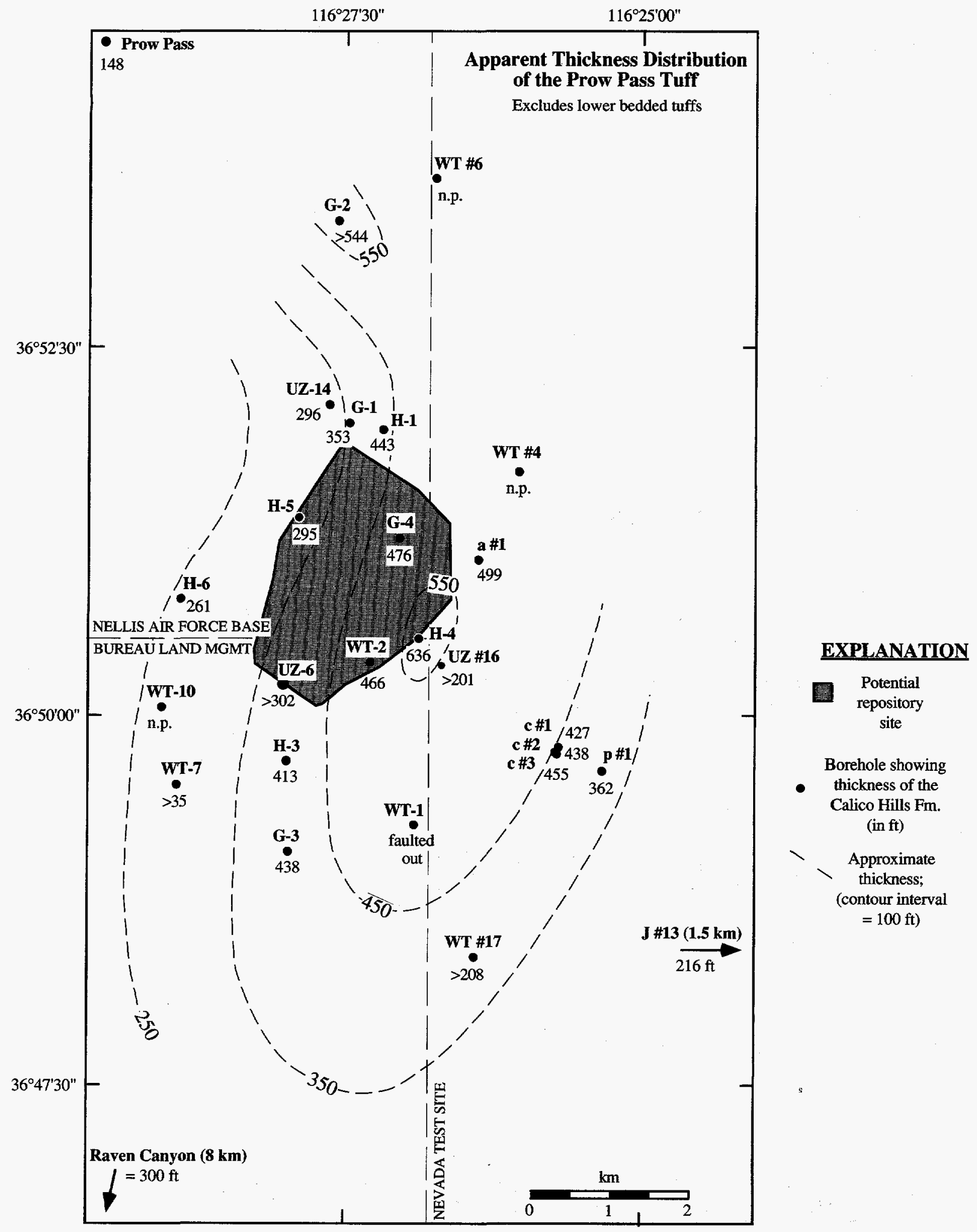

Figure 13. Thickness distribution of the Prow Pass Tuff (excluding bedded tuff unit). Heavy solid line depicts the potential repository outline. Data are from table 6 and Bentley and others (1983), Byers and Warren (1983), Craig and others (1983), Rush and others (1984), Thordarson and others (1984), Whitfield and others (1984; 1993), Carr and others (1986b), Nelson and others (1991), Geldon (1993), Peterman and others (1993), Geslin and others (1994), and R.W. Spengler, written commun. (1993). 


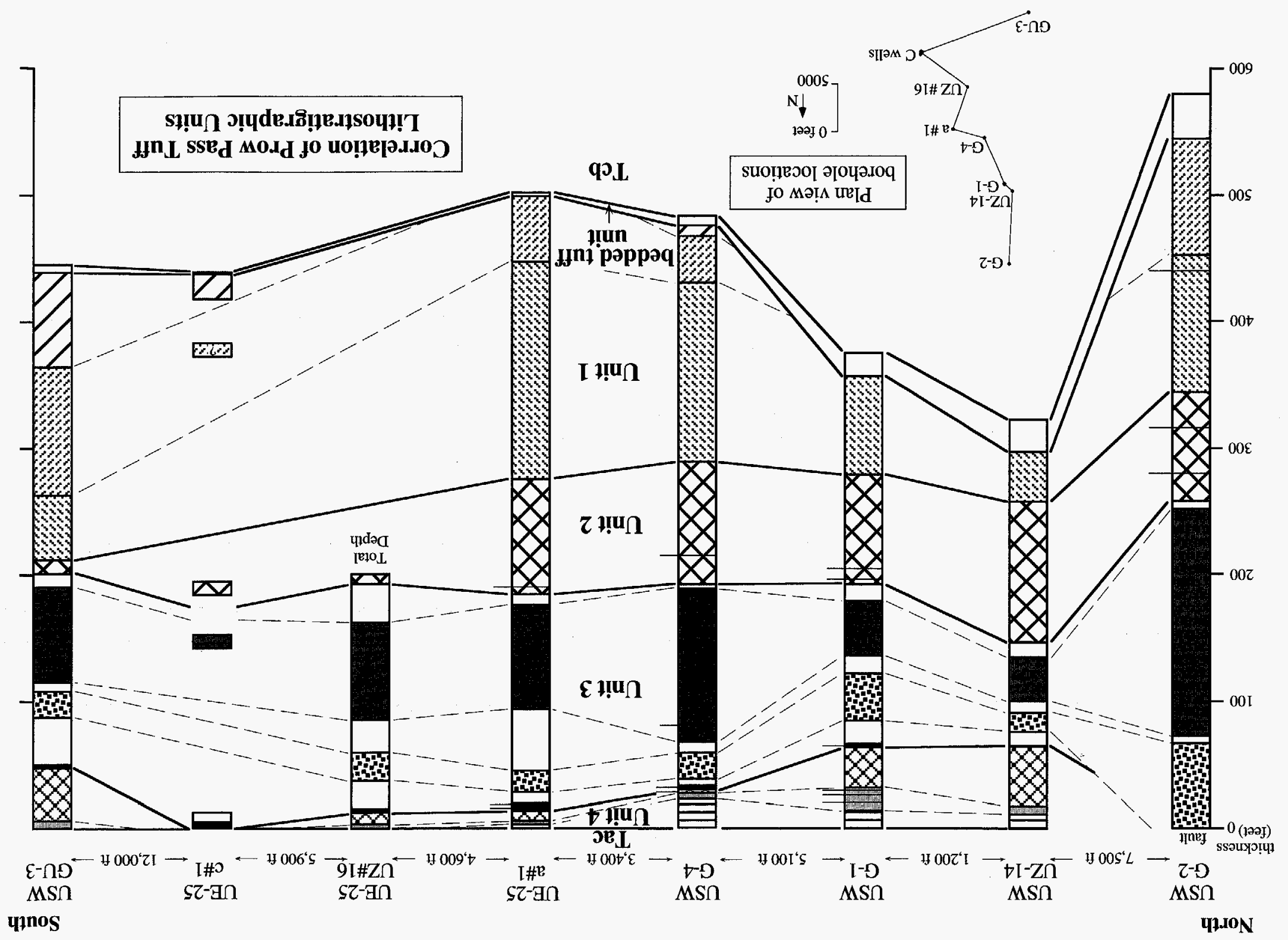


Raven Canyon. Unit 1, approximately 64-feet thick (Z.E. Peterman and others, 1994, written commun.), is nonwelded, vitric (the upper several feet are devitrified), and overlain by a pinkish ash-fall deposit. Unit 3 contains only one moderately welded subunit (the lower subunit) in this location, where the degree of welding is considerably less than beneath Yucca Mountain. The strongly vapor-phase altered subunit caps approximately 180 feet (Z.E. Peterman and others, 1994, written commun.) of unit 3 in this locale. Unit 4 maintains a substantial thickness (60 feet; Z.E. Peterman and others, 1994, written commun.) near its distal reaches in Raven Canyon. The Prow Pass Tuff overlies reworked, sandy, tuffaceous material at Raven Canyon.

The lithostratigraphic units of the Prow Pass Tuff are less distinct in exposures at Prow Pass, where the tuff is devitrified and partially- to densely welded. The formation contains sparse lithic clasts, predominantly of volcanic lithologies with subordinate siltstone. Outcrops of welded tuff near the base of the Prow Pass Tuff exposures are reddish gray with a mottled appearance texture that is typical of the lower non- to partly welded subunit of unit 3 in the Yucca Mountain region. Exposures higher in the stratigraphic section are altered by vapor-phase crystallization. Two erosionally resistant ledges that occur within the Prow Pass Tuff suggest that two cooling units are present in this locale. The field relations indicate that only unit 3 occurs at Prow Pass, where it overlies reworked deposits (possibly equivalent to unit 2) and laminated deposits of coarse ash.

\section{Mineralogy, Geochemistry, and Alteration}

The mineralogy, geochemistry, and alteration history of the Prow Pass Tuff have been studied by numerous authors (table 2). This section examines their data to define criteria that may help to identify the Prow Pass Tuff lithostratigraphic units.

\section{Phenocryst Mineralogy}

The Prow Pass Tuff has a phenocryst assemblage dominated by sanidine, plagioclase, and quartz, with subordinate biotite, orthopyroxene, and Fe-Ti oxides, and accessory hornblende, apatite, allanite, and zircon. Ferruginous orthopyroxene and extremely embayed quartz are distinguishing characteristics of the phenocryst assemblage (Broxton and others, 1989).

Figures 15 and 16 show the modal data compiled in Broxton and others (1989) plotted using the lithostratigraphic units from this report. The limited data suggest that units 2 and 3 have slightly more phenocrysts than units 1 and 4 . Phenocryst contents tend to decrease toward the lower and upper contacts of the Prow Pass Tuff (fig. 11). Sanidine and plagioclase, occurring in subequal amounts, dominate quartz in the phenocryst assemblage, with the proportion of quartz lowest in unit 1. Mafic phenocrysts comprise less than 1 percent of the rock in analyzed samples from all units (Broxton and others, 1989).

\section{Geochemistry}

The Prow Pass Tuff has a rhyolitic composition (Broxton and others, 1986) that is notably uniform in unaltered sections (Broxton and others, 1986; Peterman and others, 1993), but that is widely variable where altered to secondary minerals (Broxton and others, 1986; Peterman and others, 1993). Figure 17, which shows data collected from borehole samples at Yucca Mountain, illustrates the restricted compositional range of unit 3 when compared to other Prow Pass Tuff units. This compositional range is consistent with the composition of a vitric sample of unit 4 from borehole USW GU-3 (Broxton and others, 1986), and with the average composition of unaltered Prow Pass Tuff samples from Raven Canyon (Peterman and others, 1993). Presumably, the geochemical composition of unit 3 remains close to pristine values because welding and devitrification destroyed primary glass, thus inhibiting secondary mineral growth and the mobilization of silica, magnesium, and the alkali, alkali-earth, and high-field strength elements in a geochemically open system (Broxton and others, 1986; Peterman and others, 1993).

Figure 18 compares downhole geochemistry to lithostratigraphy in two boreholes. Particularly striking are the low $\mathrm{Ca}$ and $\mathrm{Sr}$ content, and high $\mathrm{Ba} / \mathrm{Ti}$ and $\mathrm{K} / \mathrm{Ca}$ of unit 3. Although these diagrams suggest that unit 3 may be identified from geochemical analysis of borehole cuttings, the compositional similarity of the remaining units emphasizes that whole-rock geochemistry is an unreliable indicator of lithostratigraphy (for example, compare the $\mathrm{Sr}$ content of unit 1 in boreholes UE-25a \#1 and USW G-4).

\section{Alteration History}

Studies of secondary alteration, conducted at Los Alamos National Laboratory (table 2), define two intervals of zeolite (clinoptilolite and mordenite) alteration within the Prow Pass Tuff. Figure 8c depicts the general distribution of the upper interval, designated as zeolite interval II by Vaniman and others (1984), which is confined to lithostratigraphic unit 4 of the Prow Pass 


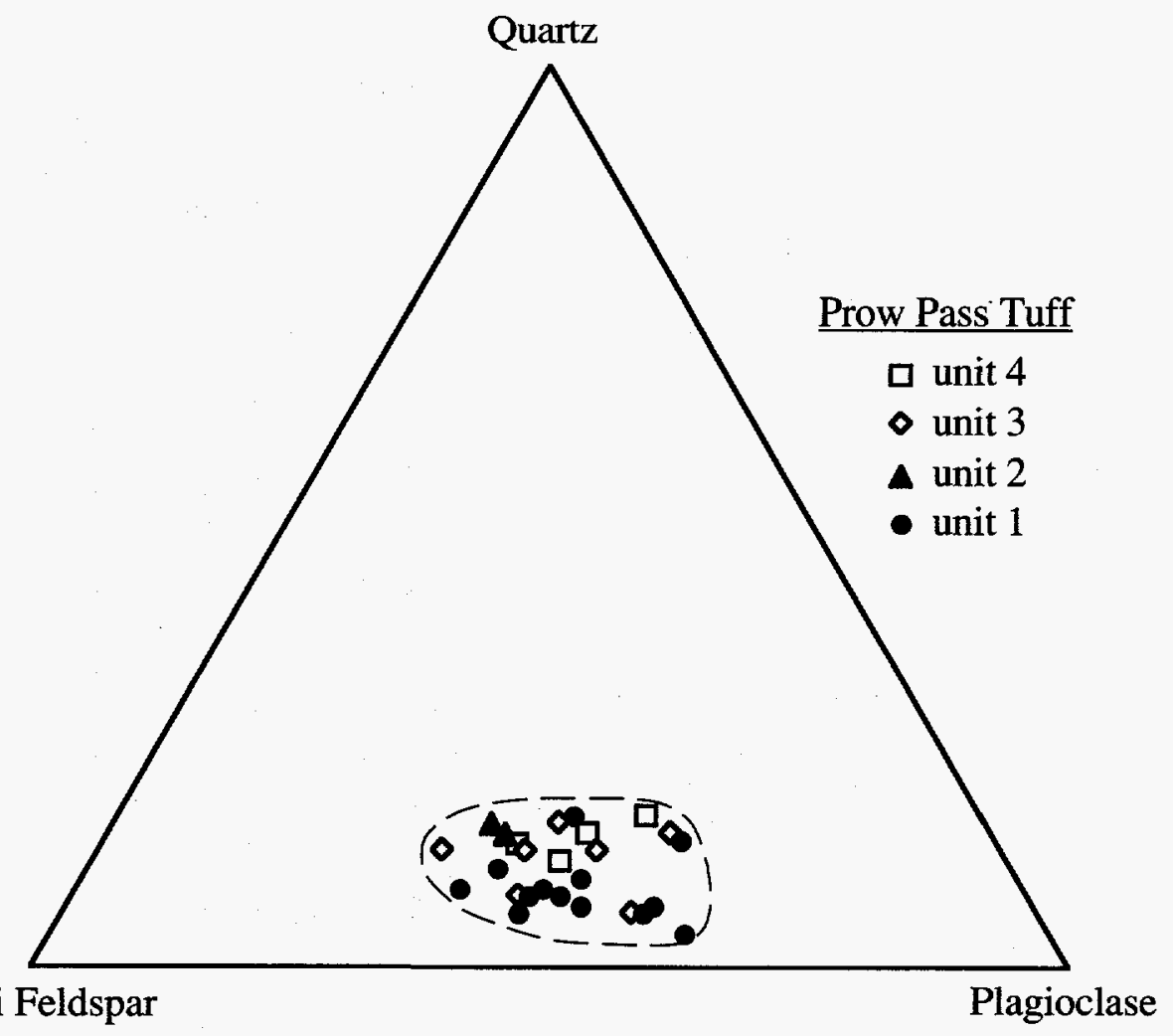

Alkali Feldspar

Plagioclase

Figure 15. Triangular plot of the proportions of quartz, sanidine, and plagioclase phenocrysts in the felsic phenocryst assemblage of the Prow Pass Tuff. Data are from Broxton and others (1989).

Tuff and to the overlying Calico Hills Formation beneath Yucca Mountain. Zeolite interval II pinches out toward the southwest where unit 4 is vitric and unaltered (for example, borehole USW GU-3). The lower interval, designated zeolite interval III by Vaniman and others (1984), occurs within units 1 and 2 in all studied boreholes, but is absent in the Raven Canyon area where unit 1 is vitric. Thus, the only Prow Pass unit unaffected by zeolite alteration is unit 3 , which is devitrified and variably welded. The lithostratigraphy, therefore controls the distribution of zeolite minerals in the Prow Pass Tuff, insofar as units that were not welded or devitrified were variably altered by ground water that converted siliceous glass to authigenic zeolite (Bish and Vaniman, 1985).

The Prow Pass Tuff largely is unaffected by smectite alteration (for example, Bish and Vaniman, 1985). Smectite abundance, as determined by semiquantitative $X$-ray diffraction, is less than 5 percent, except in a few samples from unit 2 that contain argillically altered pumice clasts.

\section{Geophysical Signatures}

Nelson and others (1991) compiled geophysical logs from boreholes at Yucca Mountain and found that gamma, resistivity, and magnetic logs contain information useful for distinguishing parts of the Prow Pass Tuff. In theory, density, porosity, and resistivity logs should distinguish the welded subunits of unit 3 from the remaining nonwelded deposits that compose the Prow Pass Tuff. However, resistivity also is sensitive to alteration (Nelson and others, 1991), which forms hydrous minerals and affects rock density by eliminating pore space.

Geophysical logs were compared to lithostratigraphic divisions to investigate whether units have unique geophysical signatures (fig. 19). Density and porosity profiles for boreholes USW G-1 and USW GU-3 depict slightly higher density and lower porosity in unit 3 than in other units, but the variations are subtle and inconsistent (compare USW G-2). However, vitric zones in USW GU-3 are distinguished by lower density and higher porosity. Other lithostrati- 


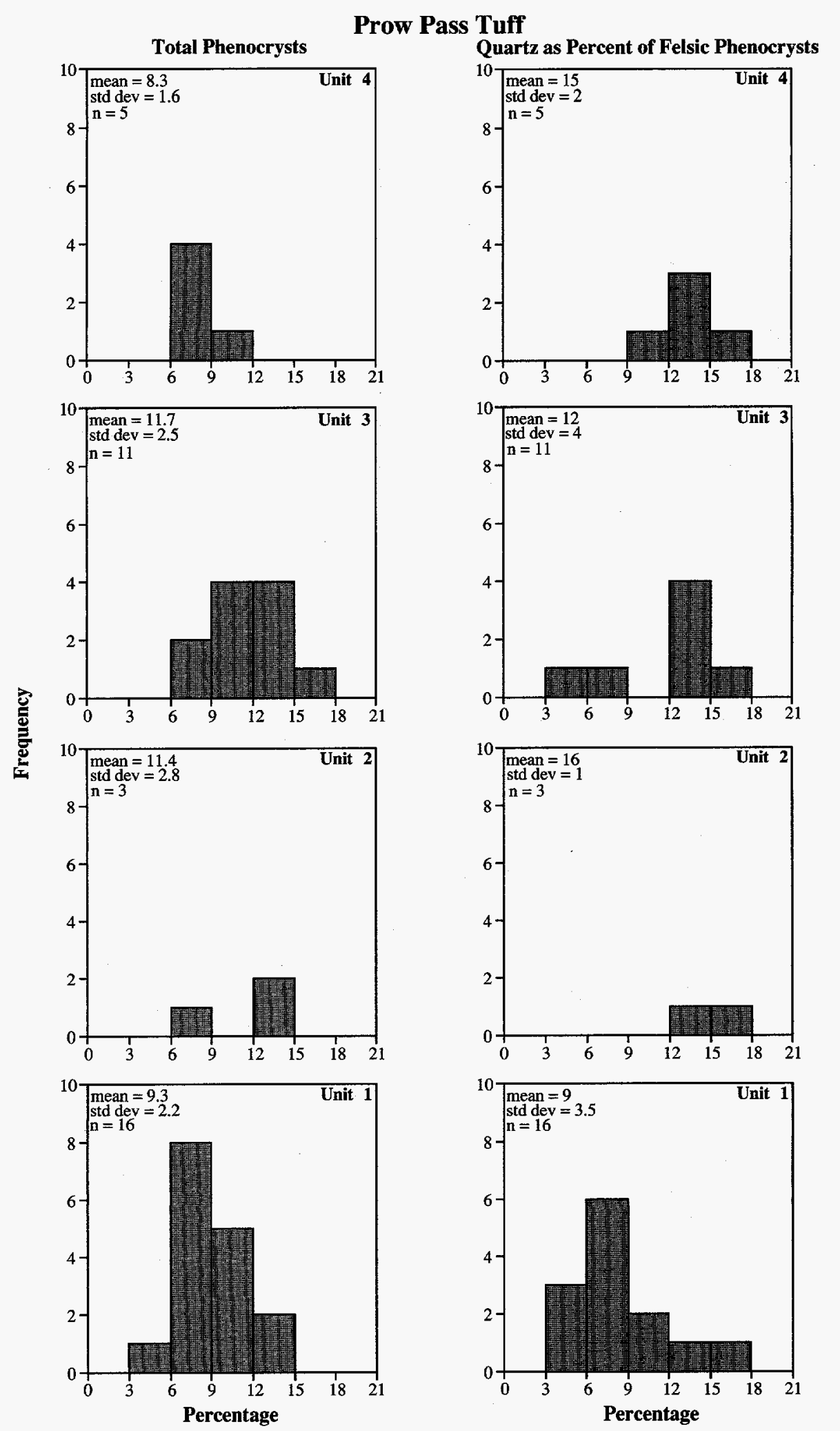

Figure 16. Histograms of phenocryst content and quartz as a percentage of the felsic phenocryst population plotted by Prow Pass Tuff lithostratigraphic unit. Note the slightly lower phenocryst contents of units 1 and 4 and the lower quartz content of unit 1. Data are from Broxton and others (1989). 


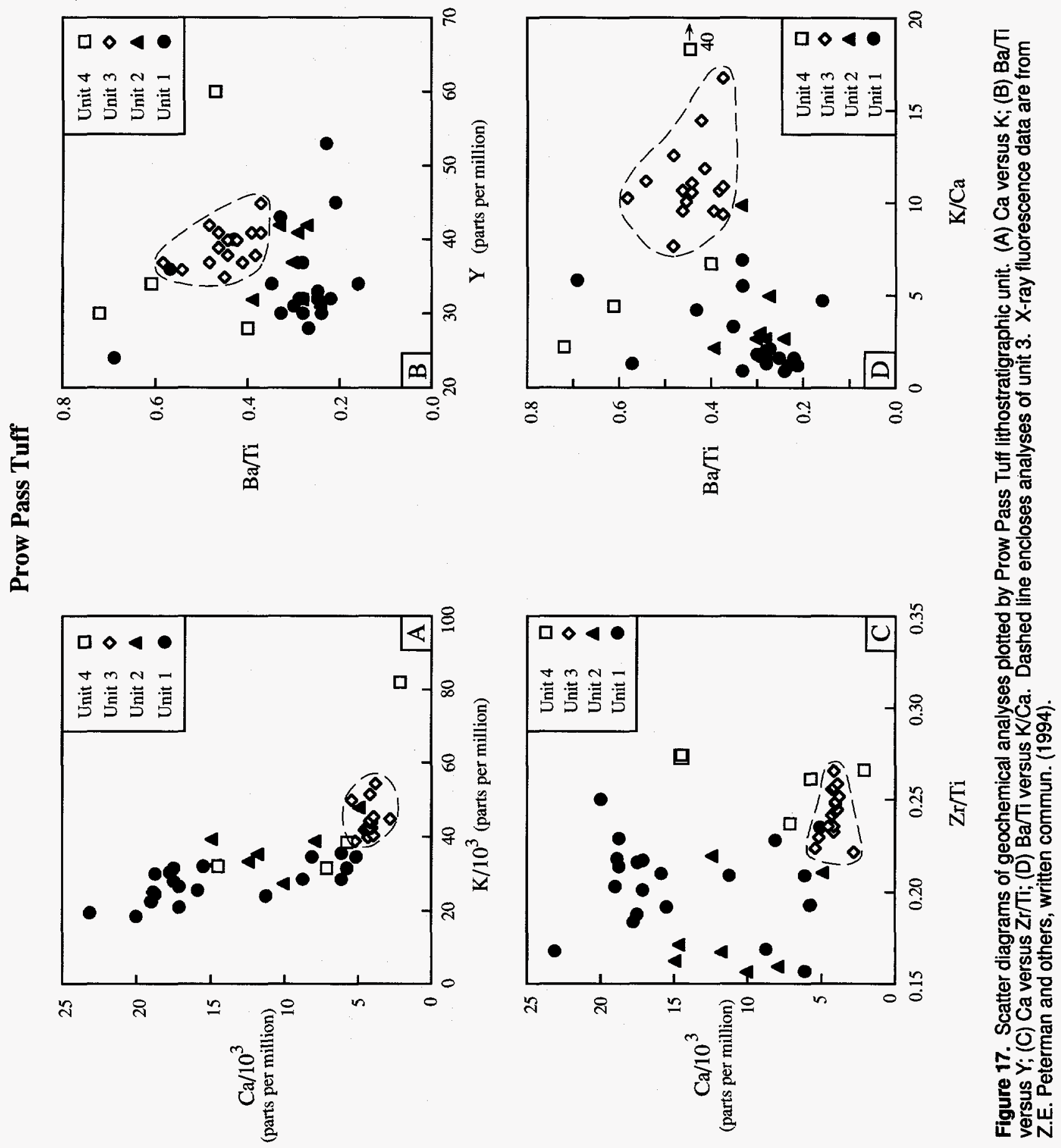




\section{Prow Pass Tuff}

UE-25 a\#1

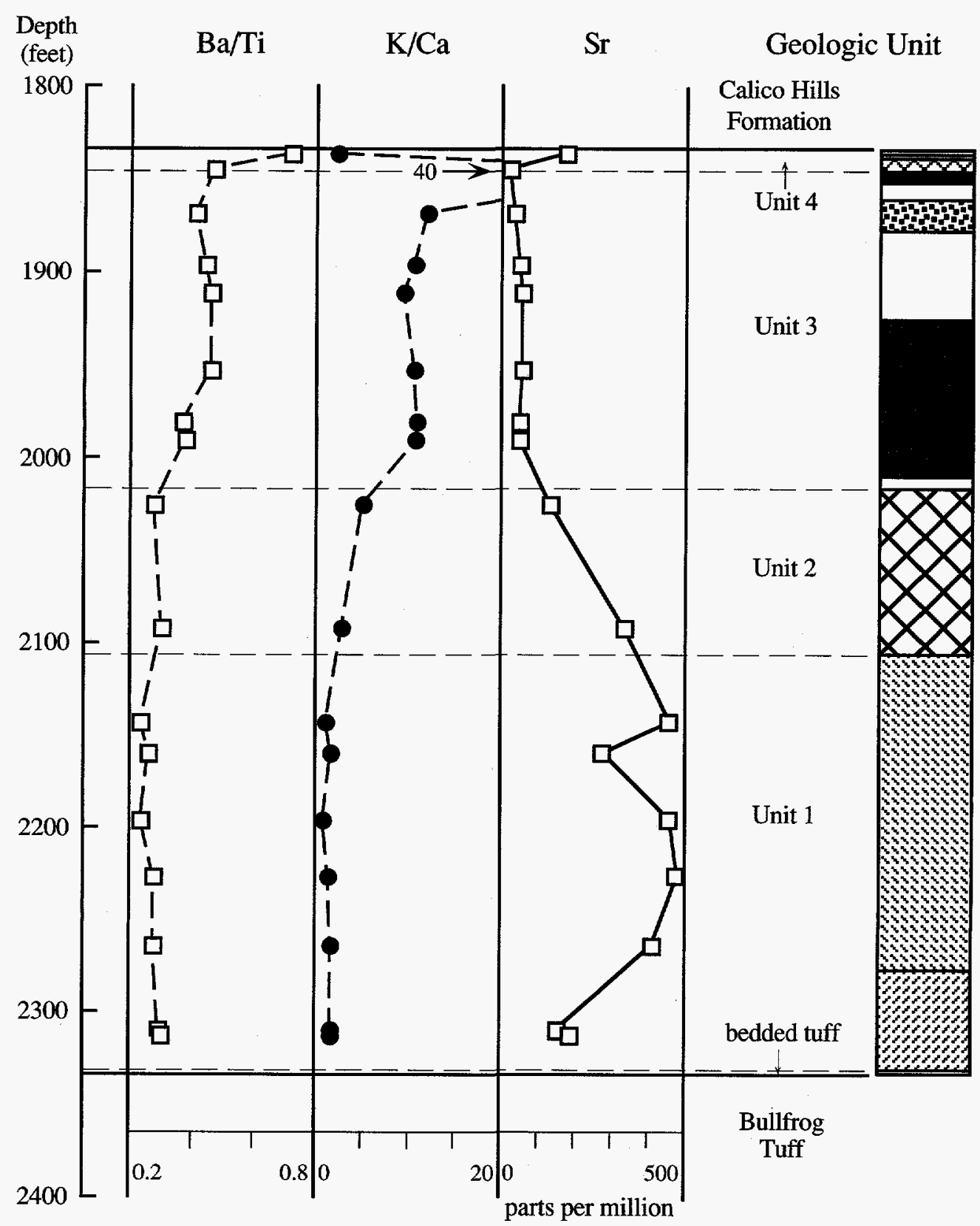

Figure 18A. Geochemistry plotted versus depth compared to lithostratigraphic units of the Prow Pass Tuff. (A) Borehole UE-25a \#1; (B) Borehole USW G-4. X-ray fluorescence data are from Z.E. Peterman and others, written commun. (1994). Stratigraphic symbols as in figure 14. Static water level from Nelson and others (1991). 


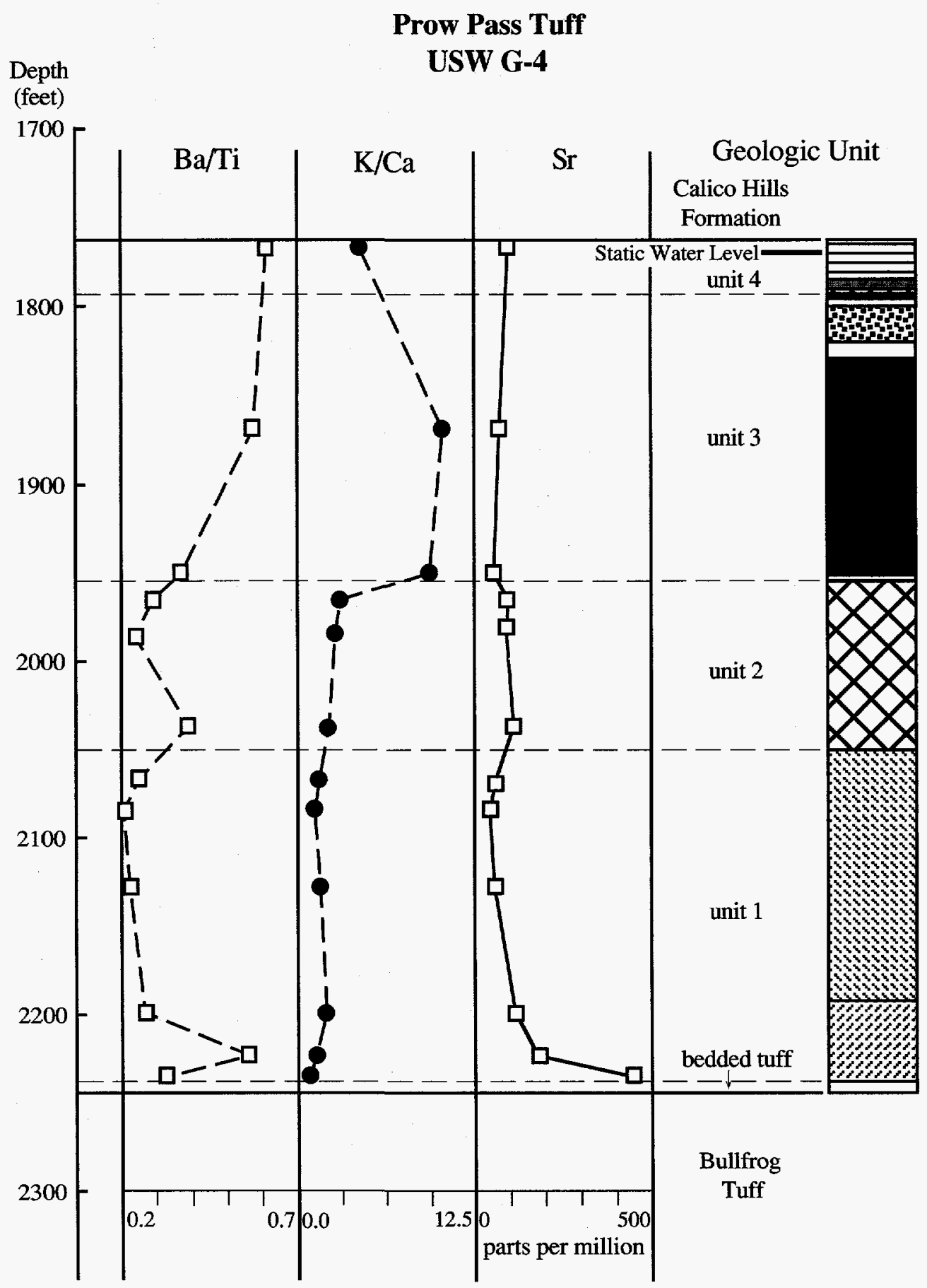

Figure 18B. Geochemistry plotted versus depth compared to lithostratigraphic units of the Prow Pass Tuff. (A) Borehole UE-25a \#1; (B) Borehole USW G-4. X-ray fluorescence data are from Z.E. Peterman and others, written commun. (1994). Stratigraphic symbols as in figure 14. Static water level from Nelson and others (1991)--Continued. 


\section{Prow Pass Tuff}

USW G-1

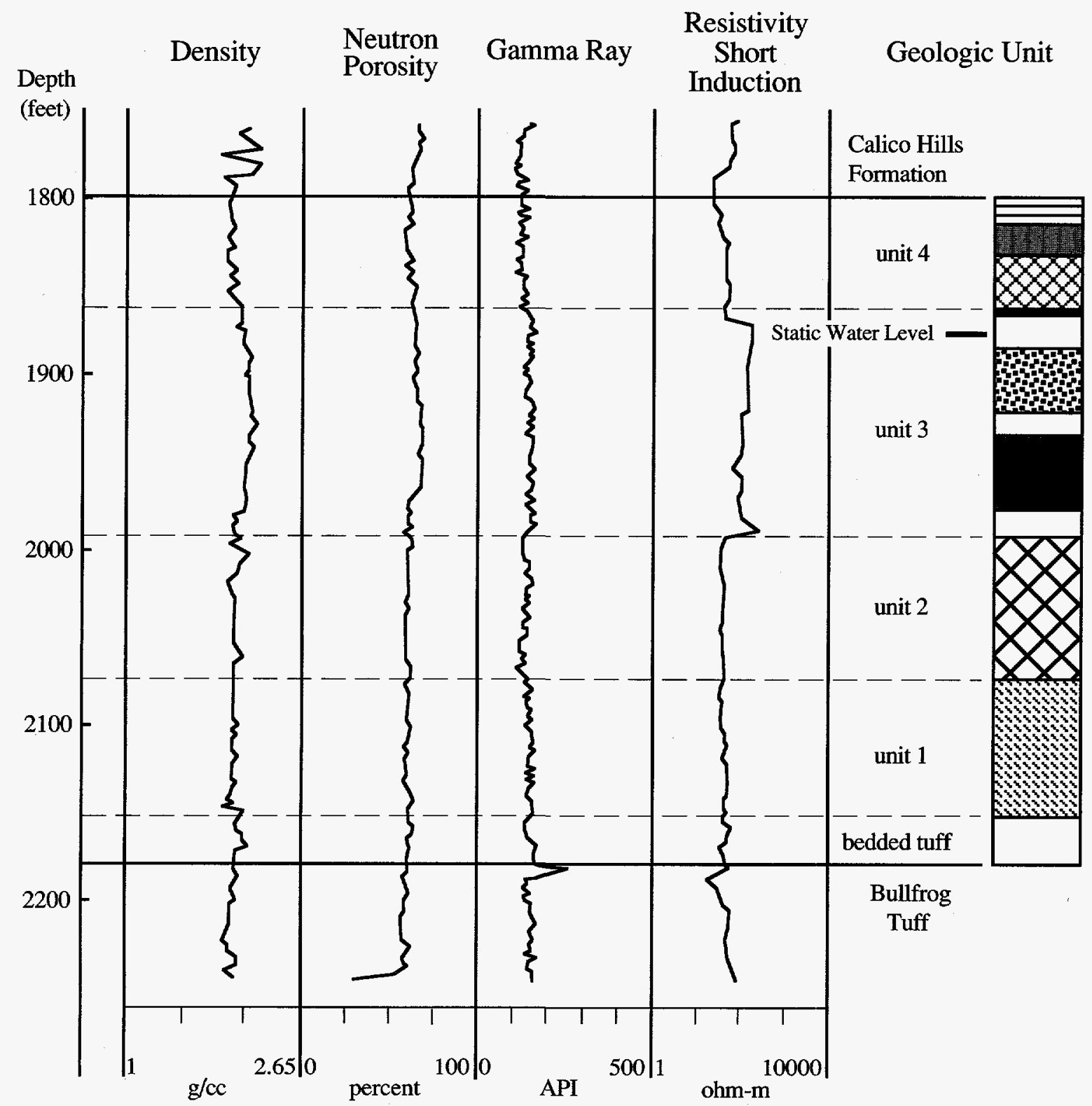

Figure 19A. Geophysical logs compared to Prow Pass Tuff lithostratigraphy. (A) Borehole USW G-1; (B) Borehole USW G-2; (C) Borehole USW GU-3. Geophysical logs are from Nelson and others (1991). Stratigraphic symbols as in figure 14. Static water level from Nelson and others (1991). 
Prow Pass Tuff

USW G-2

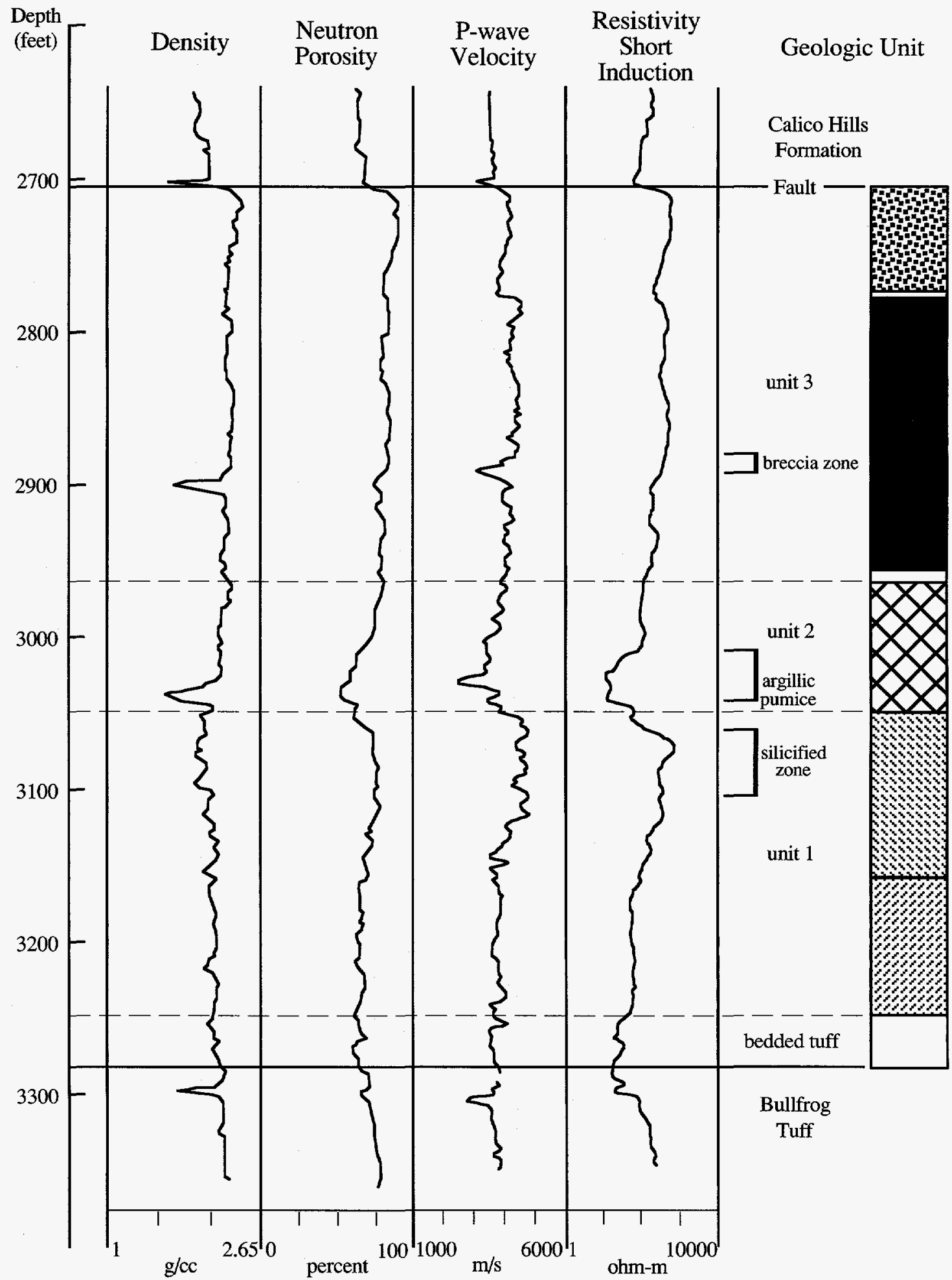

Figure 19B. Geophysical logs compared to Prow Pass Tuff lithostratigraphy. (A) Borehole USW G-1; (B) Borehole USW G-2; (C) Borehole USW GU-3. Geophysical logs are from Nelson and others (1991). Stratigraphic symbols as in figure 14. Static water level from Nelson and others (1991)--Continued. 
Prow Pass Tuff

USW GU-3

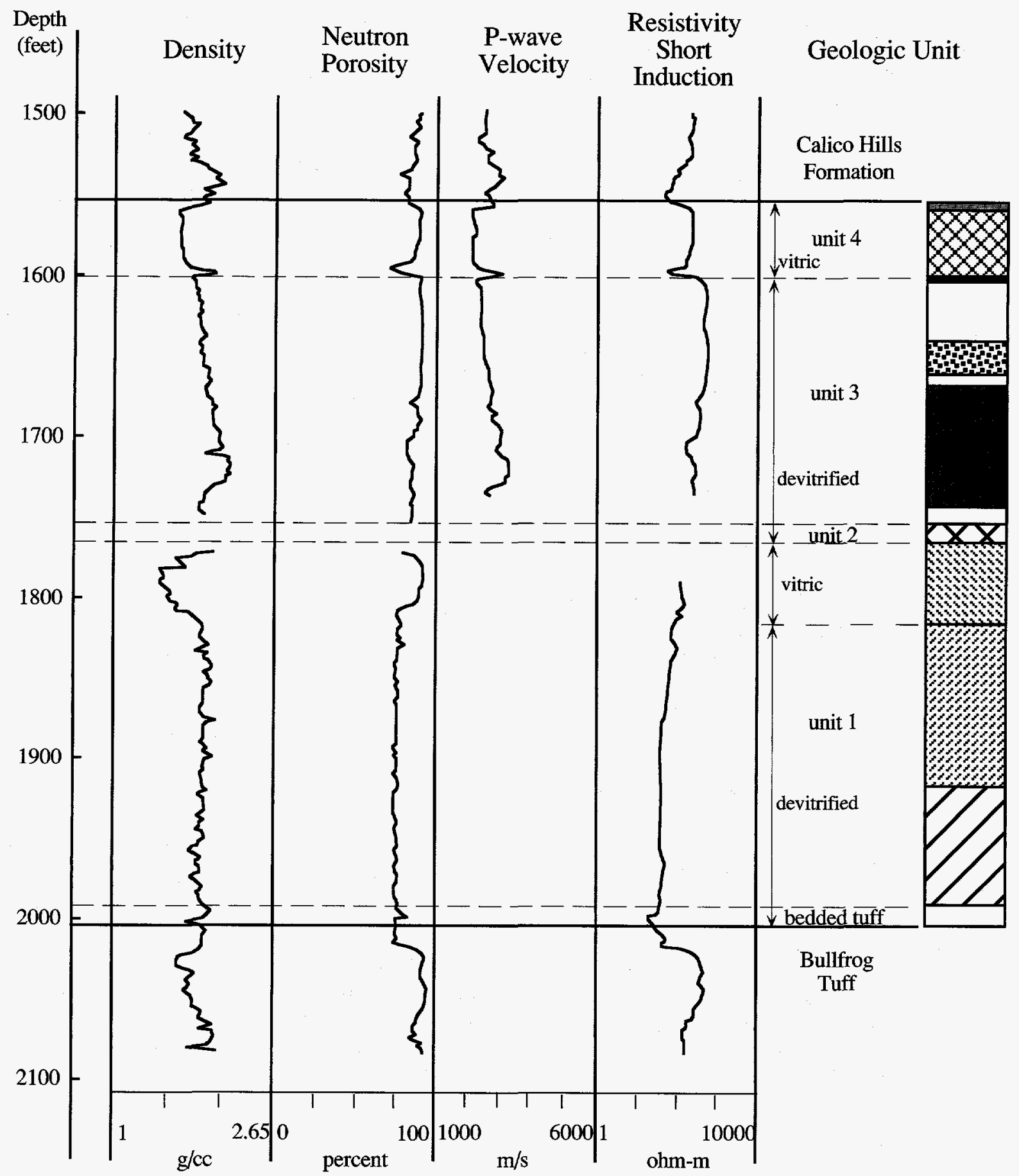

Figure 19C. Geophysical logs compared to Prow Pass Tuff lithostratigraphy. (A) Borehole USW G-1; (B) Borehole USW G-2; (C) Borehole USW GU-3. Geophysical logs are from Nelson and others (1991). Stratigraphic symbols as in figure 14. Static water level from Nelson and others (1991)--Continued. 
graphic contacts are not recognized on geophysical logs. In the absence of other data, geophysical logs cannot be used to subdivide the Prow Pass Tuff.

Resistivity logs commonly show breaks that approximate the upper and lower contacts of unit 3, which is recognized as a more resistive unit. Figure 20 shows alteration mineralogy (determined by semiquantitative $\mathrm{X}$-ray diffraction) plotted with downhole resistivity and lithostratigraphy. The inverse correlation between the amount of zeolite minerals and the electrical resistance of the upper Prow Pass units supports the contention of Nelson and others (1991) that alteration forms a recognizable signature on electrical resistivity logs. The effects of alteration also can be seen by contrasting resistivity logs of vitric and zeolitically altered unit 4 in boreholes USW GU-3 and USW G-1 (figs. 19A and C).

\section{IDENTIFICATION OF FORMATION CONTACTS}

A variety of criteria distinguish the lithostratigraphic units of the Calico Hills Formation from those of the Prow Pass Tuff, the most prominent being the ubiquitous siltstone clasts and pseudomorphic orthopyroxene of the Prow Pass Tuff. Figure 21 illustrates that the two formations also have different amounts of phenocrysts, proportions of quartz in the phenocryst assemblage, and chemical compositions. Moreover, the studies of Broxton and others (1989) show that the Prow Pass Tuff has feldspar phenocrysts that are more sodic than those in the Calico Hills Formation. Although the geophysical character of the Calico Hills Formation pyroclastic units is distinct from that of the underlying Prow Pass Tuff, the formation contact is difficult to accurately locate from geophysical logs because the signatures of the Calico Hills Formation bedded tuff and basal sandstone units are intermediate to those of the over- and underlying pyroclastic units. Nelson and others (1991) cite evidence for a persistent decrease in the magnetic field at the top of the Prow Pass Tuff that may serve as a useful geophysical marker of the formation contact; however, we did not evaluate the accuracy of this marker.
The Calico Hills and Topopah Spring Formations are distinguished by their mineralogy, chemistry, and geophysical character. Lithostratigraphic units of the Calico Hills Formation have phenocryst assemblages with a higher proportion of quartz than units of the lower Topopah Spring Tuff, despite similar phenocryst contents (Broxton and others, 1989). In addition, the Calico Hills Formation has feldspar phenocrysts that are less sodic than those of the Topopah Spring Tuff (Broxton and others, 1989). Peterman and others (1993) show that the units of the Calico Hills Formation typically have higher $\mathrm{Ca}$ and $\mathrm{Ba}$ contents than the rhyolite of the Topopah Spring Tuff. These formations experienced different welding and alteration histories that produced distinctive geophysical characteristics (Nelson and others, 1991). Nevertheless, gradual changes in the density, resistivity, magnetic susceptibility, and porosity within the lower non- to partially welded units of the Topopah Spring Tuff preclude accurate geophysical identification of this formation contact (fig. 9).

The Prow Pass and Bullfrog Tuffs can be differentiated by their phenocryst assemblage, bulk chemistry and, to some extent, their geophysical character. Units of the Prow Pass Tuff contain pseudomorphic orthopyroxene and variable, but generally, subequal amounts of biotite. In contrast, the Bullfrog Tuff lacks pyroxene, contains abundant biotite, and has slightly more quartz and less sodic feldspar than the Prow Pass Tuff (Broxton and others, 1989). Peterman and others (1993) demonstrate that the Bullfrog Tuff has a lower initial $\mathrm{Sr}$ isotopic composition and higher concentrations of $\mathrm{Ca}, \mathrm{Sr}, \mathrm{Ba}, \mathrm{Ti}$ and $\mathrm{Zr}$ than the Prow Pass Tuff. Although the geophysical character of these formations appears distinct on many logs (Nelson and others, 1991), the formation contact typically does not coincide with marked changes in geophysical parameters (fig. 19), possibly owing to the variable character of the bedded tuffs that separate the formations and to the inconsistent degree of welding of the Bullfrog Tuff beneath the contact. 


\section{Prow Pass Tuff}

\section{USW G-1}

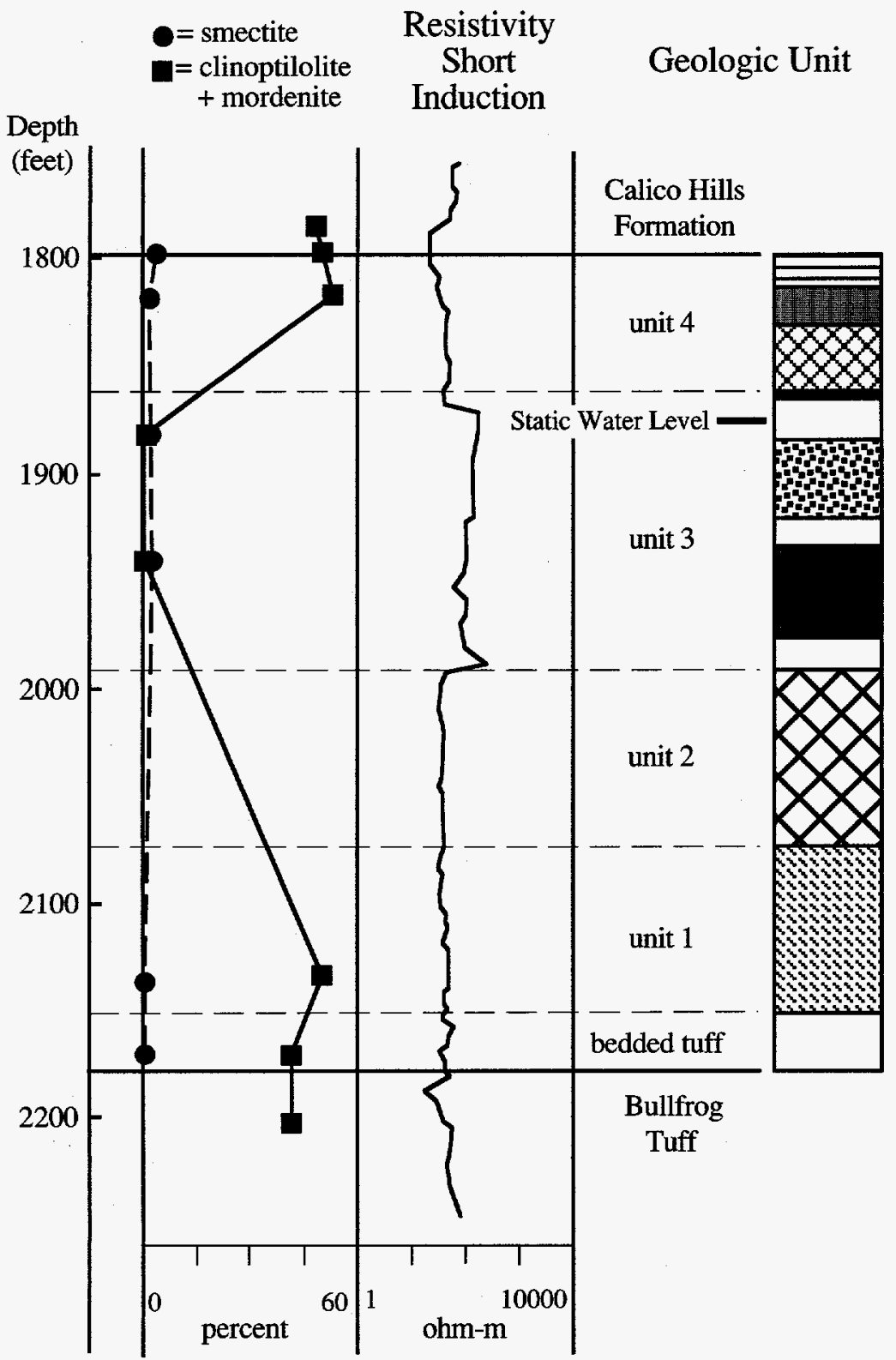

Figure 20A. Comparison of alteration mineralogy, resistivity, and Prow Pass Tuff lithostratigraphy. (A) Borehole USW G-1; (B) Borehole USW G-2; (C) Borehole UE-25a \#1. Resistivity logs are from Nelson and others (1991). Mineralogical data by semi-quantitative X-ray diffraction are from Bish and Chipera (1986) for figures $A$ and $C$ and from Caporuscio and others (1982) for figure B. Stratigraphic symbols as in figure 14. 


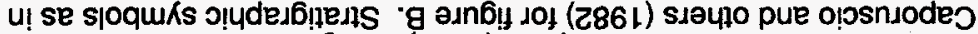

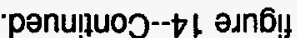

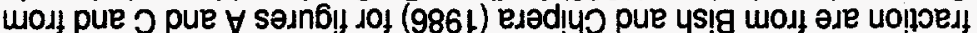

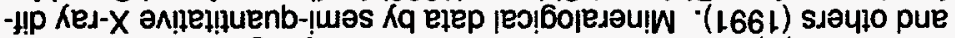

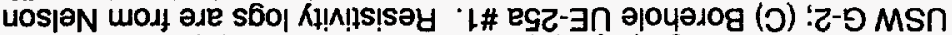

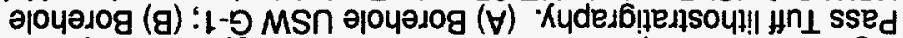

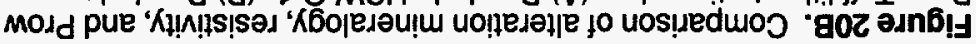

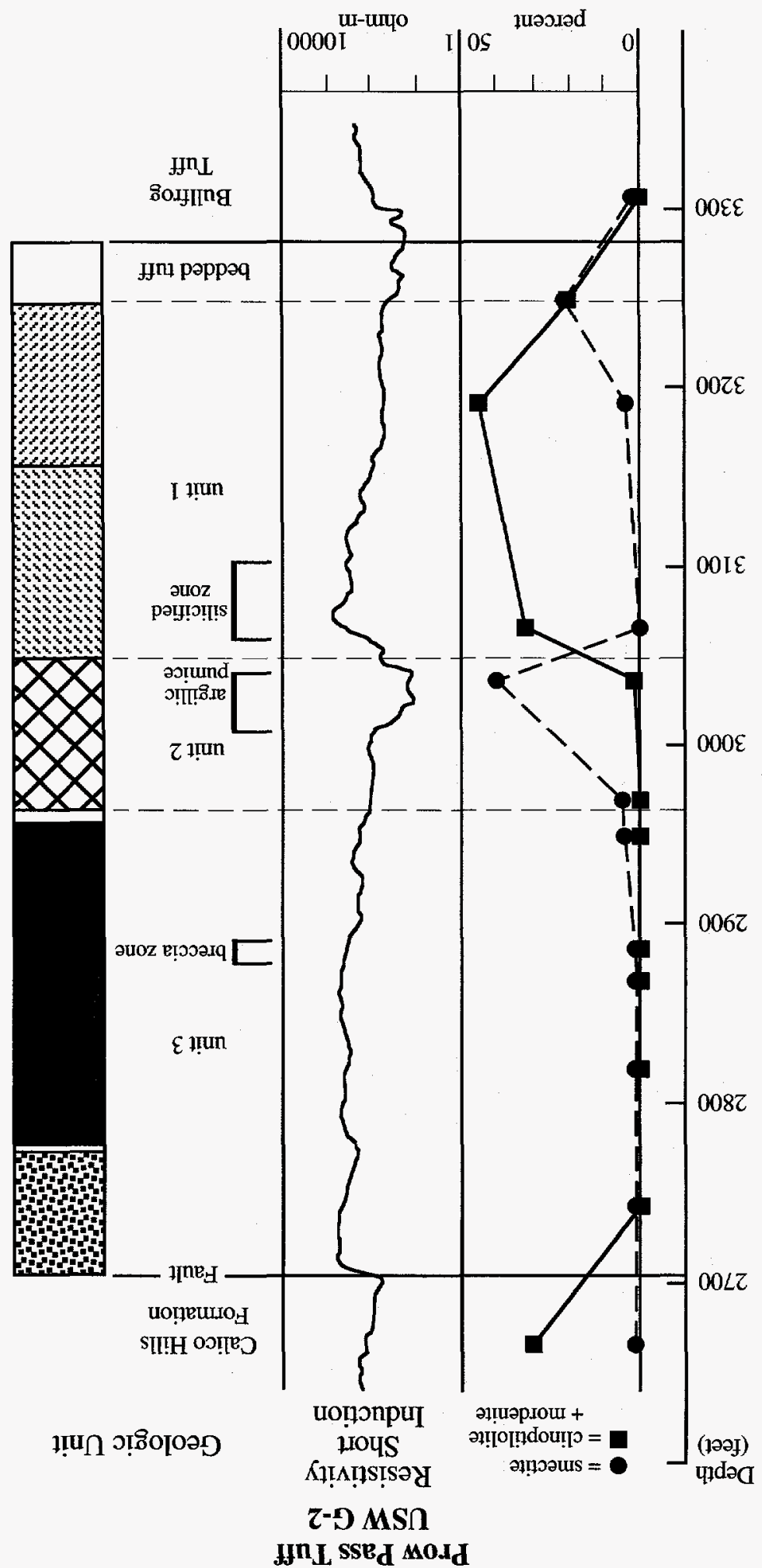




\section{Prow Pass Tuff}

UE-25 a\#1

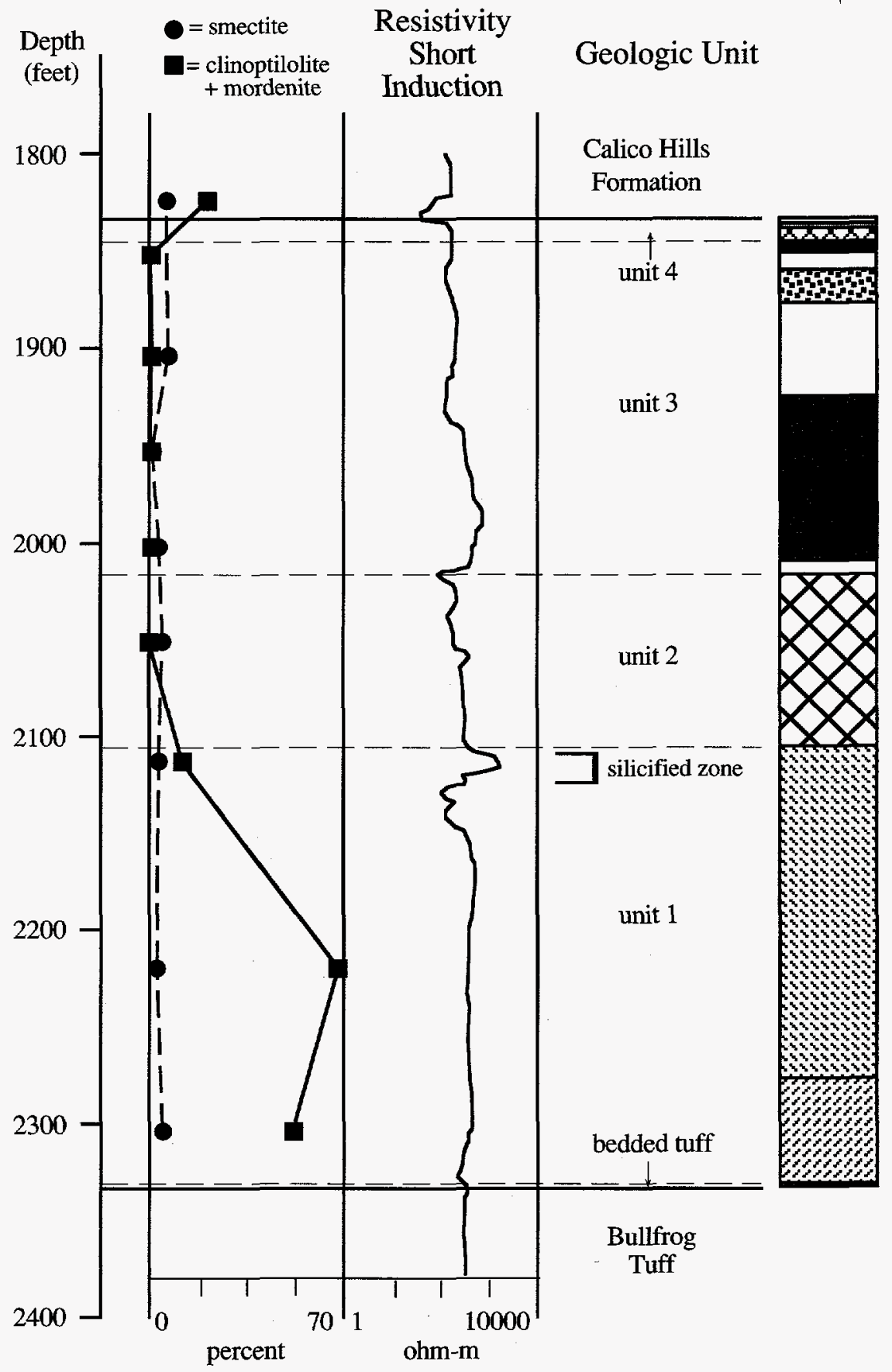

Figure 20C. Comparison of alteration mineralogy, resistivity, and Prow Pass Tuff lithostratigraphy. (A) Borehole USW G-1; (B) Borehole USW G-2; (C) Borehole UE-25a \#1. Resistivity logs are from Nelson and others (1991). Mineralogical data by semi-quantitative $X$-ray diffraction are from Bish and Chipera (1986) for figures A and $C$ and from Caporuscio and others (1982) for figure B. Stratigraphic symbols as in figure 14--Continued. 

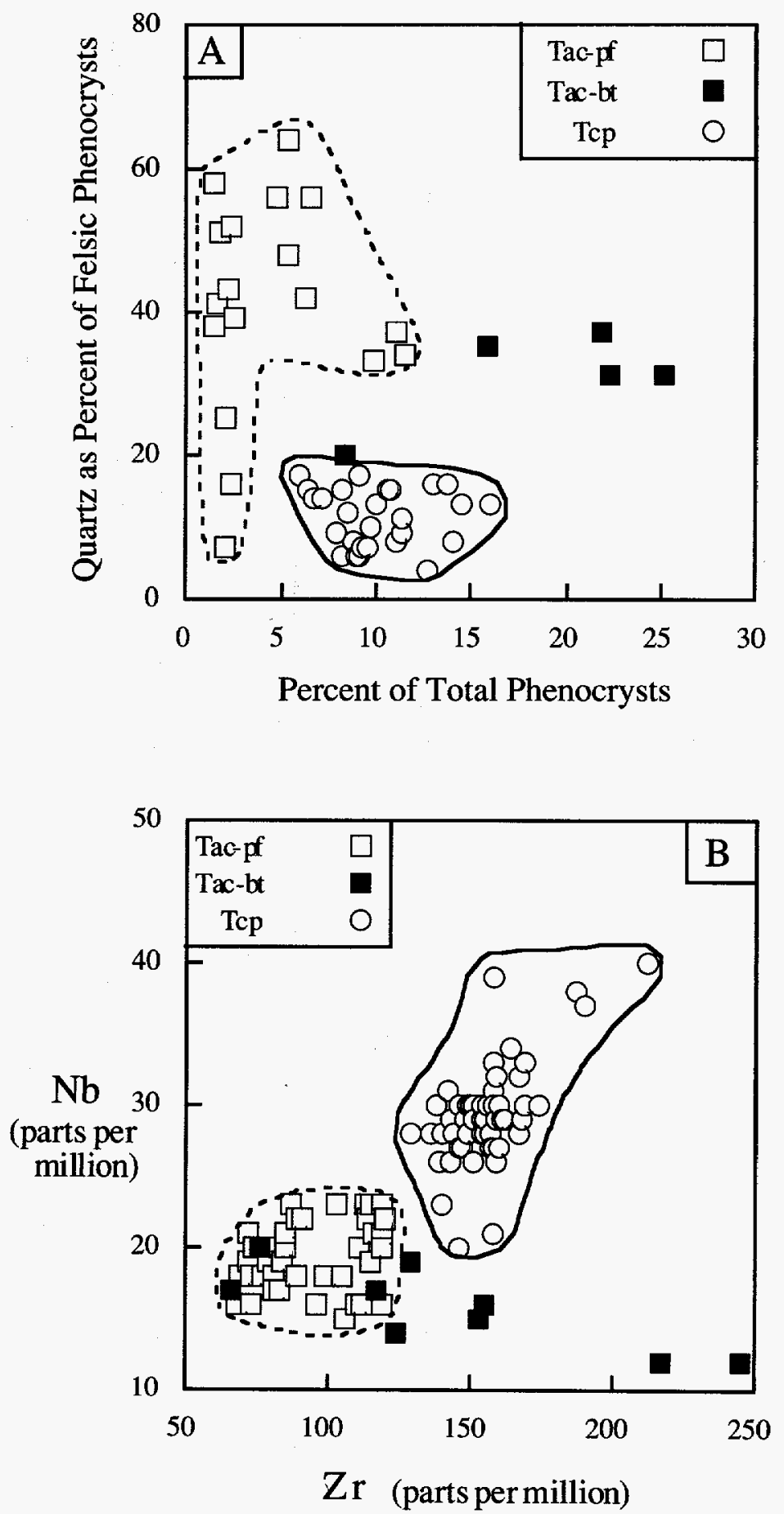

Figure 21. Comparison of the Calico Hills Formation and Prow Pass Tuff. (A) Percentage of quartz in the felsic phenocryst assemblage versus percentage of total phenocrysts. Data are from Broxton and others (1989). (B) Niobium versus zirconium. Data are from Z.E. Peterman and others, written commun. (1994). Open squares are Calico Hills Formation pyroclastic units; solid squares are Calico Hills Formation bedded tuff and basal sandstone units; open circles are Prow Pass Tuff pyroclastic units. 


\section{CONCLUSIONS}

The Calico Hills Formation and Prow Pass Tuff are divided into informal lithostratigraphic units that correlate throughout the Yucca Mountain region. The Calico Hills Formation contains five pyroclastic units, separated by fallout deposits, that overlie an interval of bedded tuff and a basal sandstone unit. The Prow Pass Tuff contains four pyroclastic units, including a welded unit with a complex cooling history, that overlie an interval of bedded tuff.

\section{ACKNOWLEDGMENTS}

R.W. Spengler (USGS) provided unpublished data and measured sections and Z.E. Peterman (USGS) and coworkers shared their database of X-ray fluorescence analyses and measured section of Raven Canyon. Z.E. Peterman and R.P. Dickerson (SAIC) provided helpful technical reviews.

\section{REFERENCES CITED}

Bentley, C.B., Robison, J.H., Spengler, R.W., 1983, Geohydrologic data for test well USW H-5, Yucca Mountain, Nye County, Nevada: U.S. Geological Survey OpenFile Report 83-853, 34 p. (NNA.890804.0009)

Bish, D.L., Caporuscio, F.A., Copp, J.F., Crowe, B.M., Purson, J.D., Smyth, J.R., and Warren, R.G., 1981, Preliminary stratigraphic and petrologic characterization of core samples from USW-G1, Yucca Mountain, Nevada: Los Alamos National Laboratory Report LA-10543-MS, 66 p. (NNA.870406.0091)

Bish, D.L., and Vaniman, D.T., 1985, Mineralogic summary of Yucca Mountain, Nevada: Los Alamos National Laboratory Report LA-10543-MS, $55 \mathrm{p}$. (HQS.880517.1073)

Bish, D.L., and Chipera, S.J., 1986, Mineralogy of drill holes J-13, UE-25A \#1, and USW G-1 at Yucca Mountain, Nevada: Los Alamos National Laboratory Report LA-10764-MS, 22 p. (NNA.890523.0057)

Broxton, D., Vaniman, D., Caporuscio, F., Arney, B., and Heiken, G., 1982, Detailed petrographic descriptions and microprobe data for drill holes USW-G2 and UE25b-1H, Yucca Mountain, Nevada: Los Alamos National Laboratory Report LA-9324-MS, 168 p. (HQS.880517.1618)

Broxton, D.E., Warren, R.G., Hagan, R.C., and Luedemann, G., 1986, Chemistry of diagenetically altered tuffs at a potential nuclear waste repository, Yucca Mountain, Nevada: Los Alamos National Laboratory Report LA-10561-MS, 160 p. (NNA.900510.0132)

Broxton, D.E., Byers, F.M., Jr., and Warren, R.G., 1989, Petrography and phenocryst chemistry of volcanic units at Yucca Mountain: A comparison of outcrop and drill hole samples: Los Alamos National Laboratory Report LA-11503-MS, 65 p. (NNA.890224.0089)

Broxton, D.E., Chipera, S.J., Byers, F.M., Jr., and Rautman, C.A., 1993, Geologic evaluation of six nonwelded tuff sites in the vicinity of Yucca Mountain, Nevada, for a surface-based test facility for the Yucca Mountain project: Los Alamos National Laboratory Report LA-12543-MS, 83 p. (NNA.930826.0064)

Buesch, D.C., and Dickerson, R.P., 1993, Intraformational deformation in the tuffs and lavas of Calico Hills exposed near Yucca Mountain, Nevada: Abstracts with Programs, Geological Society of America, v. 5, n. 25, p. 15. (MOL.19941208.0005)

Byers, F.M., Jr., and Warren, R.G., 1983, Revised volcanic stratigraphy of drill hole J-13, Fortymile Wash, Nevada, based on petrographic modes and chemistry of phenocrysts: Los Alamos National Laboratory Report LA-9652-MS, 23 p. (NNA.870406.0422)

Byers, F.M., Jr., Carr, W.J., Orkild, P.P., Quinlivan, W.D., and Sargent, K.A., 1976, Volcanic suites and related caldrons of Timber Mountain-Oasis Valley caldera complex, southern Nevada: U.S. Geological Survey Professional Paper 919, 70 p. (NNA.870406.0239)

Caporuscio, F.A., Vaniman, D.T., Bish, D.L., Broxton, D.E., Arney, B., Heiken, G.H., Byers, F.M., Gooley, R., and Semarge, E., 1982, Petrologic studies of drill cores USW G-2 and UE25b-1H, Yucca Mountain, Nevada: Los Alamos National Laboratory Report LA-9323-MS, 76 p. (NNA.870519.0041)

Caporuscio, F.A., Warren, R.G., Broxton, D.E., 1985, Detailed petrographic descriptions and microprobe data for Tertiary silicic volcanic rocks in drill hole USW G-1, Yucca Mountain, Nevada: Los Alamos National Laboratory Report LA-9323-MS, 76 p. (NNA.910117.0003)

Carr, W.J., Byers, F.M., Jr., and Orkild, P.P., 1986a, Stratigraphic and volcano-tectonic relations of Crater Flat Tuff and some older volcanic units, Nye County, Nevada: U.S. Geological Survey Professional Paper 1323, 28 p. (NNA.920921.0076)

Carr, M.D., Waddell, S.J., Wick, G.S., Stock, J.M., Monsen, S.A., Harris, A.G., Cork, B.W., and Byers, F.M., Jr., 1986b, Geology of the drill hole UE25p \#1-A test hole into pre-Tertiary rocks near Yucca Mountain, southern Nevada: U.S. Geological Survey Open-File Report 86-175, 87 p. (HQS.880517.2623)

Christiansen, R.L., and Lipman, P.W., 1965, Geologic map of the Topopah Spring NW quadrangle, Nye County, Nevada: U.S. Geological Survey Geologic Quadrangle Map GQ-444, 1 sheet, scale 1:24,000.

(NNA.921026.0008)

Christiansen, R.L., Lipman, P.W., Carr, W.J., Byers, F.M., Jr., Orkild, P.P., 1977, Timber Mountain-Oasis Valley caldera complex of southern Nevada: Geological Soci- 
ety of America Bulletin, v. 88, p. 943-959.

(NNA.900329.0044)

Craig, R.W., Reed, R.L., and Spengler, R.W., 1983, Geohydrologic data for test well USW H-6, Yucca Mountain, Nye County, Nevada: U.S. Geological Survey OpenFile Report 83-856, 35 p. (NNA.870406.0058)

Fisher, R.V., and Schmincke, H.U., 1984, Pyroclastic Rocks: Berlin, Springer-Verlag, 472 p. (NNA.910117.0005)

Frizzell, V.A., Jr., and Shulters, J., 1990, Geologic map of the Nevada Test Site, southern Nevada: U.S. Geological Survey Miscellaneous Investigations Series Map I-2046, 1 sheet, scale 1:100,000. (NNA.910123.0073)

Geldon, A.L., 1993, Preliminary hydrogeologic assessment of boreholes UE-25c \#1, UE-25c \#2, and UE-25c \#3, Yucca Mountain, Nye County, Nevada: U.S. Geological Survey Open-File Report 92-4016, 85 p. (NNA.940608.0077.0085)

Geological Society of America, 1991, Rock-color chart: Boulder, Colo., Geologic Society of America. (MOL.19940810.0002)

Geslin, J.K., Moyer, T.C., and Buesch, D.C., Summary of lithologic logging of new and existing boreholes at Yucca Mountain, Nevada, August 1993 to February 1994: U.S. Geological Survey Open-File Report 94-342, in press. (MOL.19940810.0011)

Kollmorgen Instruments Corporation, 1992, Munsell soil color charts: New York, Kollmorgen Instruments Corporation. (MOL.19940810.0003)

Maldonado, Florian, and Koether, S.L., 1983, Stratigraphy, structure, and some petrographic features of Tertiary volcanic rocks at the USW G-2 drill hole, Yucca Mountain, Nye County, Nevada: U.S. Geological Survey Open-File Report 83-732, 83 p. (NNA.870506.0143)

Muller, D.C., and Kibler, J.E., 1983, Commercial geophysical well logs from the USW G-1 drill hole, Nevada Test Site, Nevada: U.S. Geological Survey Open-File Report 83-321, 7 p. (HQS.880517.1352)

Muller, D.C., and Kibler, J.E., 1984, Geophysical logs from USW G-4, in Spengler, R.W., and Chornack, M.P., 1984, Stratigraphic and structural characteristics of volcanic rocks in core hole USW G-4, Yucca Mountain, Nye County, Nevada: U.S. Geological Survey OpenFile Report 84-789, 77 p. (NNA.870325.0101)

Nelson, P.H., Muller, D.C., Schimschal, U., and Kibler, J.E., 1991, Geophysical logs and core measurements from forty boreholes at Yucca Mountain, Nevada: U.S. Geological Survey Geophysical Investigations Map GP-1001, 64 p. (NNA.920211.0022)

Peterman, Z.E., Spengler, R.W., Singer, F.R., and Dickerson, R.P., 1993, Isotopic and trace element variability in altered and unaltered tuffs at Yucca Mountain, Nevada: High-Level Radioactive Waste Management, Proceedings of the Fourth Annual International Conference, p. 1940-1947. (NNA.940317.0059)
Rowley, P.D., Kuntz, M.A., and MacLeod, N.S., 1981, Pyroclastic-flow deposits, in Lipman, P.W., and Mullineaux, D.R., eds., The 1980 eruption of Mt. St. Helens, Washington: U.S. Geological Survey Professional Paper 1250, p. 489-512. (MOL.19941209.0020)

Rush, F.E., Thordarson, W., and Pyles, D.G., 1984, Geohydrology of test well USW H-1, Yucca Mountain, Nye County, Nevada: U.S. Geological Survey WaterResources Investigations Report 83-4032, 56 p. (NNA.870518.0067)

Sawyer, D.A., Fleck, R.J., Lanphere, M.A., Warren, R.G., Broxton, D.E., and Hudson, M.R., 1994, Episodic caldera volcanism in the Miocene southwestern Nevada volcanic field: revised stratigraphic framework, ${ }^{40} \mathrm{Ar} /{ }^{39} \mathrm{Ar}$ geochronology, and implications for magmatism and extension: Geological Society of America Bulletin, v. 106, p. 1304-1318. (MOL.19940725.0004)

Scott, R.B., 1990, Tectonic setting of Yucca Mountain, southwest Nevada, in Wernicke, B.P., ed., Basin and range extensional tectonics near the latitude of Las Vegas, Nevada: Geological Society of America Memoir 176, p. 251-282. (NNA.910923.0009)

Scott, R.B., and Castellanos, Mayra, 1984, Stratigraphic and structural relations of volcanic rocks in drill holes USW GU-3 and USW G-3, Yucca Mountain, Nye County, Nevada: U.S. Geological Survey Open-File Report 84-491, 121 p. (NNA.890804.0017)

Sparks, R.S.J., 1976, Grain size variations in ignimbrites and implications for the transport of pyroclastic flows: Sedimentology, v. 23, p. 147-188. (MOL.19941208.0006)

Spengler, R.W., and Chornack, M.P., 1984, Stratigraphic and structural characteristics of volcanic rocks in core hole USW G-4, Yucca Mountain, Nye County, Nevada, with a section on geophysical logs by D.C. Muller and J.E. Kibler: U.S. Geological Survey Open-File Report 84-789, 77 p. (NNA.890804.0012)

Spengler, R.W., Muller, D.C., and Livermore, R.B., 1979, Preliminary report on the geology and geophysics of drill hole UE25a-1, Yucca Mountain, Nevada Test Site: U.S. Geological Survey Open-File Report 79-1244, 43 p. (NNA.870406.0349)

Spengler, R.W., Byers, F.M., Jr., and Warner, J.B., 1981, Stratigraphy and structure of volcanic rocks in drill hole USW G-1, Yucca Mountain, Nye County, Nevada: U.S. Geological Survey Open-File Report 81-1349, 50 p. (NNA.870406.0222)

Sykes, M.L., Heiken, G.H., and Smyth, J.R., 1979, Mineralogy and petrology of tuff units from the UE25a-1 drill site, Yucca Mountain, Nevada: Los Alamos National Laboratory Report LA-8139-MS, 76 p. (NNA.870406.0186)

Thordarson, W., Rush, F.E., Spengler, R.W., and Waddell, S.J., 1984, Geohydrologic and drill-hole data for test 
well USW H-3, Yucca Mountain, Nye County, Nevada: U.S. Geological Survey Open-File Report 84-149, 28 p. (NNA.870406.0056)

Vaniman, D.T., Bish, D.L., Broxton, D.E., Byers, F.M., Jr., Heiken, G.H., Carlos, B.A., Semarge, R.E., Caporuscio, F.A., and Gooley, R.C., 1984, Variations in authigenic mineralogy and sorptive zeolite abundance at Yucca Mountain, Nevada, based on studies of drill cores USW GU-3/G-3: Los Alamos National Laboratory Report LA-9707-MS, 71 p. (NNA.921124.0020)

Warren, R.G., Byers, F.M., Jr., Caporuscio, F.A., 1984, Petrography and mineral chemistry of units of the Topopah Spring, Calico Hills and Crater Flat Tuffs, and older volcanic units, with emphasis on samples from Drill Hole USW G-1, Yucca Mountain, Nevada Test Site: Los Alamos National Laboratory Report LA-10003-MS, 78 p. (HQS.880517.2569)
Whitfield, M.S., Thordarson, W., Eshom, E.P., 1984, Geohydrologic and drill-hole data for test well USW H-4, Yucca Mountain, Nye County, Nevada: U.S. Geological Survey Open-File Report 84-449, 39 p.

(NNA.870407.0317)

Whitfield, M.S., Cope, C.M., and Loskot, C.L., 1993, Borehole and geohydrologic data for test hole USW UZ-6, Yucca Mountain area, Nye County, Nevada: U.S. Geological Survey Open-File Report 92-28, 28 p.

(NNA.920123.0088)

NOTE: Parenthesized numbers following each cited reference are for U.S. Department of Energy OCRWM Records Management purposes only and should not be used when ordering the publication. 



\section{APPENDICES}




\section{APPENDIX 1. DESCRIPTION OF CALICO HILLS FORMATION LITHOSTRATIGRAPHIC CONTACTS}

These criteria are used to identify the basal contacts of lithostratigraphic units within the Calico Hills Formation. It may help readers unfamiliar with the Calico Hills Formation to read upward from the stratigraphically lowest unit (basal sandstone to unit 5). The Calico Hills Formation described herein is zeolitically altered; therefore, the colors given may not apply to areas where the formation remains vitric.

\section{Pre-Topopah Spring Tuff Bedded Tuff - Calico Hills Formation}

A sharp, depositional contact above which is a well-sorted, pumiceous fallout deposit composed of pumice clasts that are from 2 to $5 \mathrm{~mm}$ diameter. Pyroclastic deposits of the Calico Hills Formation (units 5, 4 , or 3 in the Yucca Mountain region) occur below the contact.

\section{Unit 5 - Unit 4}

A sharp, depositional contact above which is a series of thinly bedded, fine-grained (less than $2 \mathrm{~mm}$ ), fall deposits. This interval ranges in thickness from 1.8 feet (in USW G-4) to 0.5 feet (in USW G-2). Overlying the fall deposits is a non- to partially welded, pumiceous pyroclastic-flow deposit that contains from 20 to 30 percent large, slightly flattened, yellowishgray to very pale orange pumice clasts in a moderate reddish-orange to grayish-pink matrix.

\section{Unit 4 - Unit 3}

A sharp, depositional contact above which is a heterolithologic sequence of thinly bedded fall deposits, reworked pyroclastic-flow deposits, and tuffaceous sandstone. A distinctive, lithic-rich fall deposit in this interval was identified in core from all four boreholes where the unit is present. This interval ranges in thickness from 14.2 feet (in USW G-2) to 0.2 feet (in UE-25 UZ \#16). Overlying these deposits is a nonwelded, pumiceous pyroclastic-flow deposit with a very pale orange to grayish-orange pink matrix that encloses from 10 to 30 percent yellowish-gray, light greenish-gray, or very pale orange pumice clasts. Present throughout the unit are large $(20$ to $70 \mathrm{~mm})$, isolated clasts of volcanic rock (rarely as accumulations of several clasts).

\section{Unit 3 - Unit 2}

A sharp, depositional contact above which is a distinctive, lithic-rich ( 30 to 40 percent) fall deposit containing devitrified, blackish-red or grayish-black, volcanic lithic clasts. This fall deposit, which varies in thickness from 4.8 feet (in USW G-2) to 1.1 feet (in USW UZ-14), underlies a nonwelded, lithic-rich, pyroclastic-flow deposit that contains from 10 to 30 percent devitrified volcanic lithic clasts in an interval near the base and in several intervals throughout the unit, and typically from 5 to 10 percent elsewhere. Obsidian lithic clasts occur locally in the pyroclastic-flow deposit (for example in USW UZ-14). The pyroclasticflow deposit has a grayish-orange to grayish-yellow or pinkish-gray matrix.

\section{Unit 2 - Unit 1}

A sharp, depositional contact above which are thinly bedded fall deposits, including several ash-fall deposits with distinctive, porcelaneous textures. The thickness of the fallout interval varies from 4.8 feet (in USW G-2) to 1.0 feet (in USW UZ-14). Overlying the fallouts is a nonwelded, pumiceous pyroclasticflow deposit with a moderate pink or moderate orangepink matrix and 20 to 40 percent very pale orange, pale yellowish-orange or white pumice clasts.

\section{Unit 1 - Bedded Tuff Unit}

A sharp, depositional contact above which is a nonwelded, lithic-rich, pyroclastic-flow deposit with a grayish-orange pink to light greenish-gray matrix. The content of devitrified volcanic lithic clasts decreases upward through the pyroclastic-flow deposit from 15 to 20 percent near the base to 3 to 7 percent at higher levels. This deposit typically contains from 7 to 12 percent phenocrysts.

\section{Bedded Tuff Unit - Basal Sandstone Unit}

A sharp, depositional contact above which is a complex, heterolithologic sequence of interbedded pyroclastic-flow deposits, coarse-grained fall deposits, and thinly bedded, porcelaneous ash-fall deposits. Some pyroclastic-flow deposits have poorly developed 
moderate-pink paleosols; many are brown and clay rich, and most contain from 13 to 25 percent phenocrysts. This contact is located at the base of the lowest fall deposit in the bedded tuff unit and is underlain by the volcaniclastic sandstone of the basal sandstone unit.

\section{Basal Sandstone Unit - Prow Pass Tuff}

A sharp, depositional contact above which is massive to laminated, immature sandstone that is very pale orange to moderate red, medium- to coarse grained, subrounded to subangular, poorly sorted, and lithic-rich, with accumulations of argillic pumice clasts and rare sedimentary structures that include load casts, pinch and swell structures, and flame structures. The basal sandstone unit may contain interbedded, reworked pyroclastic-flow deposits.

\section{APPENDIX 2. UNIT DESCRIPTIONS OF THE CALICO HILLS FORMATION}

Many of the pyroclastic units (particularly units 4 and 2) are difficult to distinguish macroscopically without stratigraphic context or marker horizons. Each pyroclastic unit contains several pyroclastic-flow deposits, many separated by thin fall deposits (most abundant in USW G-2). Pyroclastic-flow deposits with similar macroscopic characteristics are grouped into pyroclastic units. The Calico Hills Formation described herein is zeolitically altered; therefore, colors given may not apply to areas where the formation is vitric.

\section{Unit 5 - Non- to Partially Welded, Pumiceous Pyroclastic-Flow Deposit}

Matrix is moderate reddish orange to moderate orange pink to grayish pink (10R6/6, 10R7/4, 10R8/2). Pumice clasts compose 20 to 30 percent, are yellowish gray, grayish yellow, pinkish gray, and very pale orange $(5 Y 8 / 1,5$ Y8/4, 5 YR8/1, 10YR8/2). Pumice clasts have a bimodal size distribution; one size class is about 2 to $12 \mathrm{~mm}$ and the other is about 20 to $60 \mathrm{~mm}$. Some of the larger pumice clasts are slightly flattened, with visually estimated flattening ratios of 3:1. Devitrified volcanic lithic clasts ( 2 to 5 percent) are grayish brown, medium gray, and grayish black $(5 \mathrm{YR} 3 / 2, \mathrm{~N} 5, \mathrm{~N} 2)$, and mostly less than $10 \mathrm{~mm}$. Phenocrysts ( 1 to 3 percent) include sanidine, plagioclase, quartz, and biotite. The base of the unit is marked by a sequence of thinly bedded, fine-grained (less than
$2 \mathrm{~mm}$ ) fall deposits. Distinguishing characteristics: (1) pumiceous; (2) large, slightly flattened pumice clasts; (3) bimodal distribution of pumice clast sizes.

\section{Unit 4 - Nonwelded, Pumiceous Pyroclastic- Flow Deposit}

Matrix is very pale orange to grayish-orange pink (10YR8/2, 10R8/2) and grayish pink to moderate orange pink (5R8/2, 10R7/4). Top of the unit is light gray (N7) in UE-25 UZ \#16. Pumice clasts constitute 10 to 30 percent of the unit and are primarily yellowish gray, light greenish gray, very pale orange, and rarely grayish pink, light brown or white $(5 Y 8 / 1,5 G Y 8 / 1$, 10YR8/2, 5R8/2, 5YR6/4, N9). Pumice clasts are dominantly 15 to $30 \mathrm{~mm}$ in diameter. Lithic clasts compose 1 to 5 percent and include distinctive moderate reddish-orange (10R6/6), porphyritic, pumiceous tuff clasts (approximately 10 to 30 percent of the total lithic content). Other lithic clasts include devitrified volcanic rocks that are moderate brown, dark reddish brown, and medium light gray (5YR3/4, 10R3/4, N6). Most lithic clasts are less than $5 \mathrm{~mm}$, however, large lithic clasts (20 to $70 \mathrm{~mm}$ ) are scattered throughout the unit. An accumulation of large lithic clasts (up to $70 \mathrm{~mm}$ ) is present near the base of the unit in borehole UE-25 UZ \#16, and in the middle of the unit in borehole USW G-2. Phenocrysts ( 1 to 2 percent) include feldspar, quartz, and biotite. The base of the unit is marked by a heterolithologic sequence of thinly bedded fallouts, reworked pyroclastic-flow deposits, and tuffaceous sandstone. Distinguishing characteristics: (1) relatively low content of lithic clasts that occur as isolated clasts or as accumulations of several clasts; (2) abundant clasts of moderate reddish-orange tuff. Lithic-poor sections of this unit that have a grayishpink to moderate orange-pink matrix appear similar to unit 2.

\section{Unit 3 - Nonwelded, Lithic-Rich Pyroclastic- Flow Deposit}

Matrix at the top of the unit is grayish orange or very pale orange to moderate orange pink (10YR $7 / 4$, 10YR $8 / 2,10 \mathrm{R} 7 / 4$ ) with spots of grayish-orange pink (10R8/2); matrix at the base of the unit is grayish yellow to pinkish gray $(5 Y 8 / 4,5 Y R 8 / 1)$. Lithic clasts constitute from 10 to 30 percent in an interval near the base and in several intervals within the unit, but are typically 5 to 10 percent elsewhere. An accumulation of large lithic clasts ( 30 to 50 percent, up to $70 \mathrm{~mm}$ ) is present at the top of the unit in borehole UE-25 UZ \#16 
and in the middle of the unit in UE-25a \#1. Lithic clasts include blackish red, dark reddish brown, grayish brown or light gray $(5 \mathrm{R} 2 / 2,10 \mathrm{R} 3 / 4,5 \mathrm{YR} 3 / 2, \mathrm{~N} 7)$ devitrified volcanic rocks that are locally banded; black (N1) obsidian; and rare, moderate reddish-orange (10R6/6), pumiceous tuff. Obsidian clasts, which are abundant in USW GU-3 and USW UZ-14, are absent (or completely altered) in other boreholes. Pumice clasts typically compose from 10 to 25 percent of the unit, but compose up to 30 to 40 percent in the top of the unit in USW G-2. Pumice clasts are white, yellowish gray and very pale orange (N9, 5Y8/1, 10YR8/2), or rarely grayish pink (5R8/2). Phenocrysts (1 to 6 percent) include quartz, sanidine, plagioclase, and biotite (locally oxidized). The base of the unit is marked by a distinctive lithic-rich fall deposit with 30 to 40 percent clasts of devitrified volcanic rocks that are blackish red $(5 \mathrm{R} 2 / 2)$ or grayish black (N2). This fallout is a marker horizon observed in core from all boreholes (except USW GU-3). In USW GU-3, where it is brown and clay-rich, unit 3 may be a distal reworked sedimentary facies. The presence of obsidian lithic clasts is used to tentatively correlate strata above the bedded tuff unit in USW GU-3 with unit 3. Distinguishing characteristics:

(1) lithic-rich fall deposit at the base of the unit;

(2) abundant lithic clasts in the pyroclastic-flow deposit.

\section{Unit 2 - Nonwelded, Pumiceous Pyroclastic- Flow Deposit}

Matrix is moderate pink or moderate orange pink (5R7/4, 10R7/4), with a zone in the upper part of the unit that is grayish pink or grayish-orange pink $(5 R 8 / 2$, $5 Y R 7 / 2$ ) with spots of pale red purple (5RP6/2). Pumice clasts compose from 20 to 40 percent of the rock and are very pale orange, pale yellowish orange, white, and grayish pink or grayish yellow (10YR8/2,

$10 \mathrm{YR} 8 / 6, \mathrm{~N} 9,5 \mathrm{R} 8 / 2,5 \mathrm{Y} 8 / 4)$. Most pumice clasts are less than $20 \mathrm{~mm}$ in diameter. Lithic clasts constitute from 1 to 3 percent, increasing to 3 to 5 percent downward in some boreholes. Lithic clasts include blackishred $(5 R 2 / 2)$ or moderate brown (5YR3/4) devitrified volcanic rocks, and rare, moderate reddish-orange (10R6/6), clasts of pumiceous tuff. Thin fall deposits are common in the middle of the unit. Phenocrysts (1 to 6 percent) include sanidine, plagioclase, quartz, and biotite. The base of the unit is marked by a thin sequence of interbedded pumice-fall deposits and porcelaneous ash-fall deposits. Distinguishing characteristics: (1) pumice rich; (2) distinctive moderate pink or moderate orange-pink matrix; (3) very pale orange or white pumice clasts.

\section{Unit 1 - Nonwelded Lithic-Rich Pyroclastic- Flow Deposit}

Matrix is grayish-orange pink, pinkish gray, light greenish gray or rarely moderate orange pink (5YR8/1, 10R8/2, 5GY8/1, 10R7/4). Devitrified volcanic lithic clasts ( 3 to 7 percent at top increasing to 15 to 20 percent at base) are grayish red or moderate brown (5R4/2,5YR3/4) and rarely porphyritic, and light gray or grayish pink (N7,5R8/2), and aphyric. Lithic clasts, which are mostly less than $15 \mathrm{~mm}$, increase in size in the lower part of the unit (up to 50 to $60 \mathrm{~mm}$ in USW G-1), then decrease in size near the base. Pumice clasts ( 10 to 15 percent, rarely to 20 percent) are white to pale greenish yellow (N9,10Y8/2). Phenocrysts ( 7 to 12 percent) include quartz, feldspar and biotite. Distinguishing characteristics: (1) lithic-rich with increasing lithic content near the base of the unit; (2) light colored matrix; (3) phenocryst content is lower than pyroclastic-flow deposits in the subjacent bedded tuff unit, but is higher than superjacent pyroclastic units.

\section{Bedded Tuff Unit}

A complex heterolithologic package of interbedded pyroclastic-flow deposits (many reworked), coarse-grained fall deposits, and thinly bedded, porcelaneous ash-fall deposits. Pyroclastic-flow deposits are five- to ten-feet thick (thicker in USW G-2) and locally have poorly developed paleosols. Some deposits are brown and clay-rich suggesting they are reworked. Phenocryst content in pyroclastic-flow deposits can be as high as 25 percent, and includes feldspar, quartz, and biotite. Pyroclastic-flow deposits are thicker to the north, up to 116.1 feet in USW G-2. Distinguishing characteristics: (1) abundance of fall deposits; (2) high phenocryst content of the pyroclastic-flow deposits; (3) reworked appearance of many of the pyroclastic-flow deposits; (4) thin, porcelaneous ash-fall deposits.

\section{Basal Sandstone Unit}

Massive to laminated, immature sandstone, very pale orange, moderate red or moderate pink (10YR8/2, 5R5/4, 5R7/4), medium- to coarse grained, subrounded to subangular, poorly sorted, lithic-rich, with accumulations of argillic pumice clasts that are 2 to $4 \mathrm{~mm}$ in diameter. Rare sedimentary structures (for example at $1754.5 \mathrm{ft}$ in USW G-4) include load casts, pinch-andswell structures, and flame structures that indicate post- 
deposition water expulsion. Rare, interbedded pyroclastic-flow deposits are moderate red to moderate pink (5R5/6, 5R7/4), clay-rich, and reworked. Distinguishing characteristics: Immature volcaniclastic sandstone lithology.

\section{APPENDIX 3. DESCRIPTIONS OF PROW PASS TUFF LITHOSTRATIGRAPHIC CONTACTS}

\section{Calico Hills Formation - Prow Pass Tuff}

A sharp, locally irregular, depositional contact. Red or light gray, immature volcaniclastic sandstone of the Calico Hills Formation overlies poorly-sorted, pyroxene-bearing, grayish-orange pink ash of Prow Pass Tuff unit 4. A pumice-rich fallout overlies Prow Pass Tuff unit 4 in borehole UE-25 UZ \#16.

\section{Unit 4}

Upper subunit - Middle subunit. A gradational (typically over less than $1 \mathrm{ft}$ ) contact based on the abrupt downward increase of pumice clasts from 3 to 10 percent above the contact to 10 to 20 percent below.

Middle subunit - Lower subunit. A gradational (typically over less than $0.3 \mathrm{ft}$ ) contact based on the abrupt downward increase in the sizes of pumice clasts from 3 to $12 \mathrm{~mm}$ above the contact to 10 to $40 \mathrm{~mm}$ below the contact.

\section{Unit 4 - Unit 3}

A generally sharp contact that separates an overlying pumiceous pyroclastic-flow deposit from a zone of strongly altered and vapor-phase crystallized tuff. Pseudomorphic pyroxene occurs only in the matrix of the underlying tuff but is present in both the matrix and pumice clasts of the overlying subunit. Alteration has obscured probable depositional relationships, but the upper part of subunit 3 appears locally as a fine-grained ash (USW G-1).

\section{Unit 3}

All contacts between subunits are gradational (typically over less than $1 \mathrm{ft}$ ). The contact between the strongly vapor-phase altered subunit and upper non- to partially welded subunit is marked by the presence of corroded pumice fragments above the contact that imparts a "spongy" appearance to the rock. Contacts between all other subunits are based on the average shape of pumice clasts in the range of 10 to $30 \mathrm{~mm}$ diameter. Non- to partially welded subunits have pumice clasts that are non- to slightly deformed (average flattening ratios are typically 2.0 to 4.0 ), whereas moderately welded subunits have variably deformed pumice fragments (average flattening ratios are typically from 4.0 to 6.5 ).

\section{Unit 3 - Unit 2}

A depositional contact at which a locally preserved, thin (1 to $10 \mathrm{~mm}$ ) fall horizon separates an overlying lithic-poor ( 1 to 3 percent lithic clasts) from an underlying lithic-rich ( 3 to 5 percent lithic clasts) pyroclastic-flow deposit. The moderate red (5R4/4) fallout varies from pumice- and crystal-rich (crystals of plagioclase, sanidine, quartz, biotite, and pseudomorphic pyroxene) to predominantly ash. Where the fallout is absent, the contact is defined by the abrupt increase in lithic clast content.

\section{Unit 2 - Unit 1}

A depositional contact marked by a dusky red (5R3/2) to moderate orange-pink (5YR8/4) fallout. The locally preserved fall deposit, which varies from 1 to $20 \mathrm{~mm}$ in thickness, contains very pale orange (10YR8/2) pumice clasts, siltstone lithic clasts, and crystals of plagioclase, sanidine, quartz, and biotite. It separates a pyroclastic-flow deposit with moderately sized pumice clasts ( 10 to $20 \mathrm{~mm}$ diameter) and abundant ( 3 to 5 percent) lithic clasts above from a pyroclastic-flow deposit with larger pumice clasts (10 to $40 \mathrm{~mm}$ ) and fewer lithic clasts (1 to 3 percent) below. Where the fallout is absent, the contact is defined by the abrupt change in lithic content and pumice size.

\section{Unit 1}

Upper subunit - Middle subunit. A locally preserved depositional contact marked by a thin (1 to $2 \mathrm{~mm}$ ) ash parting. The parting separates an overlying lithic-poor (1 to 3 percent) pyroclastic-flow deposit from an underlying lithic-rich ( 3 to 5 percent) pyroclastic-flow deposit. Where the fallout is absent, the contact is marked by the abrupt change in lithic content 
that may be accompanied by an increase in pumice size.

Middle subunit - Lower subunit. This depositional contact is marked by a locally preserved, thin $(2 \mathrm{~mm})$, ash-fall deposit that separates an overlying lithic-rich ( 3 to 5 percent) pyroclastic-flow deposit from an underlying lithic-poor (1 to 3 percent) pyroclastic-flow deposit. Where the fallout is absent, the contact is marked by the abrupt change in lithic content.

\section{Unit 1 - Bedded Tuff}

A sharp, depositional contact that separates overlying an pyroclastic-flow deposit from an underlying deposit of laminated ash.

\section{Bedded Tuff}

Laminated ash - Reworked tuffaceous deposits. A sharp, depositional contact in which thinly laminated ash overlies either pumiceous tuffs (reworked fallout deposits?) or the Bullfrog Tuff.

\section{Bedded Tuff - Bullfrog Tuff}

A sharp, depositional contact that separates an underlying pyroclastic-flow deposit from a variety of overlying deposits that locally include a mono- or heterolithologic breccia, reworked(?) pumiceous tuffs, reworked(?) pyroclastic-flow deposits, or laminated ash. Contacts between these deposits may be depositional (base of upper pyroclastic-flow deposit; top of basal breccia) or gradational over less than 0.3 feet (all other contacts). The Bullfrog Tuff at the contact varies from nonwelded to moderately welded and is recognized by increases in the amounts of biotite and quartz.

\section{APPENDIX 4. UNIT DESCRIPTIONS OF THE PROW PASS TUFF}

The Prow Pass Tuff comprises four pyroclastic units that overlie a variable sequence of bedded tuffs. Distinguishing characteristics of this formation include the presence of orthopyroxene pseudomorphs (Broxton and others, 1989) and the abundance of siltstone lithic clasts (Spengler and others, 1981). Unit contacts are defined by locally preserved ash-fall horizons and abrupt changes in the sizes and amounts of pumice and lithic clasts. Variations in the abundance of lithic clasts or the degree of welding are used to further subdivide the units. Subunits may vary in thickness and may be difficult to distinguish where stratigraphic context is lacking. Subunits are described below in descending stratigraphic position.

\section{Unit 4 - Pyroxene-Rich Pyrociastic Deposits}

This nonwelded unit is composed of three irregularly distributed subunits that are separated by gradational contacts. Subunits are distinguished by changes in the average diameter and percentage of pumice clasts which increase stratigraphically downward. The upper subunit is a massive, ash-rich bed that may be a pyroclastic-flow deposit (locally reworked) as indicated by the degree of sorting of the matrix, although its origin is unclear. The middle subunit is a pyroclastic-flow deposit, possibly reworked, that locally comprises four flow units. The lower subunit is a pyroclastic-flow deposit that locally comprises two flow units.

The pyroxene-rich unit is distinguished by comparatively abundant pseudomorphic pyroxene in pumice clasts and the rock matrix and by a comparatively low ratio of felsic to mafic phenocryst minerals. Distinctive pumice clasts with large (up to $3 \mathrm{~mm}$ ) plagioclase crystals characterize the lower subunit.

Phenocrysts include abundant sanidine, plagioclase, quartz, subordinate partially oxidized biotite, pseudomorphic pyroxene, and Fe-Ti oxides, and rare hornblende. Lithic clasts in unit 4 are predominantly siltstone or mudstone in various shades of moderate reddish-brown (10R4/6) and grayish-red (10R3/2), and subordinate volcanic lithologies that include light brown (5YR6/3) porphyritic lava, grayish-red (5R4/2) lava, and grayish-black (N2) lava(?).

Upper subunit. The devitrified and altered matrix grades upward from grayish-orange pink (5YR8/2) to a mottled mix of pinkish gray (5YR8/1, $5 Y R 8 / 2)$ and light olive gray $(5 Y 7 / 2)$ to grayishorange pink (10R8/2) to moderate orange pink (10R7/4). Argillic alteration, especially prominent in the upper 2 to 3 feet, has destroyed shard textures. Pumice clasts, which compose from 3 to 10 percent of the rock, are white (N9), where altered to fine-grained vapor-phase minerals or grayish-orange pink (10R8/2), where argillically altered, and typically smaller than $5 \mathrm{~mm}$ (but locally up to $15 \mathrm{~mm}$ ). Phenocrysts decrease upward from 5 to 7 percent near the base of the subunit to 2 to 4 percent near the upper contact. Pyroxene pseudomorphs are common throughout except in strongly altered zones. Lithic clasts constitute from 1 to 2 percent of the subunit and are typically 
smaller than $5 \mathrm{~mm}$, but vary up to $10 \mathrm{~mm}$ (rarely to $25 \mathrm{~mm}$ ).

Middle subunit. The matrix is light gray (N7), very pale orange (10YR8/2, 10YR8/1), or grayishorange pink (5YR7/2), and devitrified with variably preserved shard textures. In borehole USW GU-3, the pale orange-brown (10YR7/2) ashy matrix is vitric with sparse colorless shards. Pumice clasts are nondeformed to slightly deformed, and white (N9) where devitrified, grayish orange (10YR7/3) where vitric, and brownish-orange pink (5YR7/4) to very pale orange (10YR8/2), or pale red $(5 \mathrm{R} 7 / 2)$ to moderate red (5R5/4) where argillically altered. They constitute from 10 to 20 percent of the rock (locally 3 to 5 percent) and are commonly from 3 to $12 \mathrm{~mm}$ in diameter. Some pumice clasts contain from 3 to 10 percent phenocrysts of plagioclase (up to $3 \mathrm{~mm}$ ), sanidine, quartz, biotite, and pyroxene pseudomorphs. Phenocrysts compose from 10 to 15 percent of the rock; lithic clasts constitute approximately 1 percent of the rock (locally 2 to 3 percent) and are from 1 to $5 \mathrm{~mm}$ in diameter (but up to $15 \mathrm{~mm}$ ).

Lower subunit. The matrix is light gray (N7) to white (N9), pale orange-brown (10YR7/2), light brownish gray (5YR6/1), pinkish gray (10YR8/1), or grayish pink (10R7/1), devitrified, and altered. Where vitric, the ash-rich matrix is friable and very pale orange (10YR8/2), with sparse colorless glass shards. Pumice clasts compose from 15 to 25 percent of the rock, are nondeformed to slightly deformed, typically from 10 to $40 \mathrm{~mm}$ in diameter (but up to $60 \mathrm{~mm}$ ), and contain from 5 to 10 percent phenocrysts of plagioclase (up to $3 \mathrm{~mm}$ ), sanidine, quartz, biotite, and pyroxene pseudomorphs. Devitrified pumice clasts are very pale orange (10YR8/2), white (N9), or pinkish gray $(10 \mathrm{YR} 8 / 1)$, argillically altered pumice clasts are grayish-orange pink (5YR7/3 to 5YR8/2), and vitric pumice clasts are grayish orange (10YR7/4). Sparse biotite-rich pumice clasts are grayish-orange pink (5YR7/2). Phenocrysts constitute from 10 to 12 percent of the rock; lithic clasts compose from 1 to 2 percent and are typically from 1 to $5 \mathrm{~mm}$ in diameter (but up to $10 \mathrm{~mm}$ and rarely $25 \mathrm{~mm}$ ).

\section{Unit 3 - Welded Pyroclastic-Flow Deposit}

This unit comprises six subunits separated by gradational contacts defined by variations in the degree of welding or features of secondary crystallization. It is a compound cooling unit that has two zones of moderate welding discerned by variations in the flattening of pumice clasts between 10 and $30 \mathrm{~mm}$ in long dimension. Clasts larger than $30 \mathrm{~mm}$ may not be deformed in the upper cooling zone, which is thinner and generally less dense than the lower cooling zone. Secondary crystallization and alteration obscures variations in matrix density created by the welding process. A thin zone of intense vapor-phase alteration, within which pumice clasts are strongly corroded, marks the top of unit 3. Coarse-grained vapor-phase crystallization of pumice clasts in the lower moderately welded subunit in some boreholes suggests that a second zone of vapor-phase crystallization products is associated with the lower cooling unit. Although a distinct lithologic discontinuity has not been identified between the cooling zones (a possible bedding break occurs in borehole USW G-4), the unit comprises multiple flow units as indicated by interbedded ash-fall horizons and variations in the abundance and size of pumice and lithic clasts.

The distinguishing characteristics of this unit are a light gray to light red color, 10 to 20 percent pumice clasts, 7 to 12 percent phenocrysts, and 1 to 4 percent lithic clasts. Pumice clasts generally lack phenocrysts; however, they may contain feldspar, quartz, or biotite phenocrysts. Distinctive biotite-rich pumice clasts, which are a few percent of the pumice population, are pale grayish red (10R5/2), pale red (10R6/2), or grayish-orange pink (5YR8/2). Phenocrysts within the rock matrix are predominantly quartz, plagioclase, and sanidine in subequal amounts, subordinate biotite and irontitanium oxides, and sparse to rare pyroxene pseudomorphs and hornblende. Lithic clasts are predominantly siltstone or mudstone in various shades of grayish brown (5YR3/2), moderate brown (5YR4/3, $5 Y R 4 / 4)$, moderate to pale reddish brown (10R4/4, $10 \mathrm{R} 4 / 6,10 \mathrm{R} 5 / 4)$, dusky grayish red (5R4/3), or grayish red (10R4/2). Subordinate volcanic lithologies include pale red (10R6/2) to grayish-red (10R4/2) porphyritic lava, pale brown (5YR6/2) to light brownish-gray (5YR6/1) felsic lava, reddish-orange brown (10R5/6) lava, medium gray (N5) to grayish-orange pink (5YR7/2) biotite-rich porphyry, grayish-black (N2) to brownish-black (5YR2/1) lava(?), and rare, grayishorange pink (10YR8/4, 10YR7/4, 10YR8/3) biotiteand feldspar-bearing tuff.

Strongly vapor-phase altered subunit. The matrix is pale brown (5YR5/2), light olive gray (5Y6/1), light to medium light gray (N8 to N6), devitrified, and strongly altered by vapor-phase fluids that have destroyed shard textures. Pumice clasts, which are devitrified, replaced by vapor-phase minerals, and strongly altered and corroded, are pale yellowish brown (10YR6/2), medium- to light gray (N6 to N8), or white (N9). They constitute from 10 to 15 percent of the rock, are nondeformed, and generally have a long dimension less than $15 \mathrm{~mm}$ (but are locally larger). 
Phenocrysts compose from 7 to 10 percent of the unit. Lithic clasts, typically smaller than $5 \mathrm{~mm}$ in diameter but as large as $10 \mathrm{~mm}$, constitute from 1 to 3 percent of the rock.

Upper non- to partially welded subunit. The matrix is white- to light gray (N9 to N7), pinkish gray (7.5YR8/1), light brownish gray (5YR7/1), or very pale orange (10YR8/2), altered to fine-grained vaporphase minerals, and devitrified. Shard textures are absent. Pumice clasts, which are devitrified and altered to vapor-phase minerals, are light brownish gray (5YR6/1), grayish-orange pink (5YR7/2), pale red (10R6/2), or medium-light gray (N6). They compose from 10 to 15 percent of the rock, are nondeformed, and generally have a long dimension less than $15 \mathrm{~mm}$ (but may be up to $35 \mathrm{~mm}$ ). Phenocrysts constitute from 7 to 10 percent of the unit (locally 5 to 7 percent). Lithic clasts, typically smaller than $5 \mathrm{~mm}$ in diameter but as large as $20 \mathrm{~mm}$, compose from 1 to 2 percent of the rock.

Upper moderately welded subunit. The matrix is pale red (10R6/2) to grayish-red (10R4/2), light brownish-gray (5YR6/1), grayish-orange pink (5YR7/2), pinkish-gray (7.5YR8/1), or white (N9), devitrified and altered to fine-grained vapor-phase minerals, but locally moderate red (10R5/4) where silicified. Shard textures typically are absent, but may be locally preserved in the upper part of the unit. Pumice clasts that are devitrified and altered to fine-grained vapor-phase minerals are pale red (10R6/2), grayish-orange pink (5YR7/2), or light brownish gray (5YR6/1). Pumice clasts that are spherulitically devitrified are grayishorange pink (10R8/2), moderate orange pink (10R7/4) to moderate reddish orange (10R6/6) or pale red (10R6/2), or light orange pink (5YR8/2) to pinkish gray $(5 Y R 8 / 1)$. Variably deformed pumice clasts (flattening ratios greater than 4) that compose 5 to 15 percent of the unit (locally from 2 to 20 percent) typically are smaller than $20 \mathrm{~mm}$ in long dimension (but may be up to $45 \mathrm{~mm}$ ). Phenocrysts constitute from 7 to 12 percent of the unit (locally 5 to 7 percent). Lithic clasts, typically with diameters less than $5 \mathrm{~mm}$ but as large as $20 \mathrm{~mm}$, compose from 1 to 2 percent of the rock in the upper part of the unit. Lithic content locally increases downward to 2 to 3 percent in the lower part of the unit.

Middle non- to partially welded subunit. The matrix is light gray (N7) to very light gray (N8) or light brownish gray (5YR6/1, 5YR7/1), devitrified and altered to fine-grained vapor-phase minerals. Shard textures commonly are absent. Devitrified pumice clasts that are altered to fine-grained, vapor-phase minerals are light brownish gray (5YR6/1), pinkish gray (5YR8/1 to 5YR8/2), medium light gray (N6) to light gray (N7), or white (N9). They are nondeformed, com- pose from 10 to 20 percent of the unit, and are typically smaller than $15 \mathrm{~mm}$ in diameter (but may be up to $35 \mathrm{~mm}$ ). Phenocrysts constitute from 7 to 12 percent of the unit (locally 5 to 7 percent). Lithic clasts, typically smaller than $5 \mathrm{~mm}$ in diameter but as large as $20 \mathrm{~mm}$, compose from 1 to 3 percent of the rock.

Lower moderately welded subunit. The matrix, which generally becomes pinker downward as welding increases, may be light gray (N7), very light gray (N8), light brownish gray to pinkish gray (5YR6/1 to $5 \mathrm{YR} 8 / 1)$, very pale orange (10YR8/2, 10YR9/1), pale yellowish brown (10YR6/2), medium grayish pink (5R7/2), pale red (10R6/2), grayish red (10R5/1), or pale orange pink (10R7/3, 10R8/3). It is devitrified with vapor-phase minerals that decrease in amount downward; shard textures are rarely preserved. Where altered, the matrix is light brown (5YR6/4), grayishorange pink (10R8/2), or moderate red (5R4/4).

Deformed pumice clasts with flattening ratios greater than 4 constitute 10 to 20 percent of the rock (locally less), are devitrified (spherulites and axiolites occur locally), variably altered to fine-grained vapor-phase minerals or to clays, and typically smaller than $25 \mathrm{~mm}$ (but with clasts to $45 \mathrm{~mm}$ ). Pumice clasts may be pinkish gray to moderate orange pink (5YR8/1 to 5YR8/4), light brown (5YR6/4), grayish-orange pink to light orange brown (5YR7/2 to 5YR7/4), very pale orange (10YR8/2, 10YR8/1), light grayish brown (10YR7/1), or white (N9). Where altered to clay minerals they may be pale orange pink (10R7/2), and where replaced by coarse vapor-phase minerals they are medium dark gray (N4). Phenocrysts compose from 7 to 12 percent of the unit (locally 5 to 7 percent). Lithic clasts, typically smaller than $5 \mathrm{~mm}$ in diameter but as large as 20 to $60 \mathrm{~mm}$ (tending to be larger southward), constitute from 1 to 4 percent of the rock. Siltstone lithic clasts commonly are altered near the base of the unit, with indistinct margins enclosed by moderate orangepink (10R7/4) rims and white (N9) haloes.

Lower non- to partially welded subunit. The matrix, which is devitrified, altered to vapor-phase minerals, and typically oxidized, has a color that may be light to very light gray (N7 to N8) or pale red (5R6/2, 5R7/3). Pumice clasts are not deformed, compose from 5 to 15 percent of the rock, are devitrified and altered to vapor-phase minerals or opal, and typically smaller than $25 \mathrm{~mm}$ in diameter. Pumice colors are white (N9), pinkish gray (5YR8/1), or where altered, pale reddish brown (10R5/4). Phenocrysts compose from 7 to 12 percent of the unit (locally 5 to 7 percent). Lithic clasts, typically smaller than $5 \mathrm{~mm}$ in diameter but as large as $15 \mathrm{~mm}$, constitute from 1 to 3 percent of the rock. Siltstone lithic clasts commonly are altered with indistinct margins enclosed by moder- 
ate orange-pink (10R7/4) or pale reddish-brown (10R5/4) rims and white (N9) haloes.

\section{Unit 2 - Lithic-Rich Pyroclastic-Flow Deposit}

This non- to partially welded pyroclastic-flow deposit comprises three macroscopically similar flow units. Flow unit contacts are identified by locally preserved ash partings or abrupt changes in the amounts and sizes of pumice and lithic clasts. Grain size variability in the upper part of borehole G-1 suggests intraflow shear, whereas the fine-grained base of the deposit in boreholes G-1 and G-2 may represent shearing along the substrate. This unit is distinguished by abundant lithic clasts and an equigranular texture imparted by the similar sizes of pumice and lithic clasts.

The devitrified and altered matrix is pale red (10R6/2) to grayish-orange pink (10R8/2), very pale orange (10YR8/2, 10YR8/1), pinkish gray (5YR8/1, $5 Y R 8 / 2$ ), medium gray (N5) to light gray (N7), or moderate red (5R4/4, 5R6/4). Where zeolitized, the matrix is yellowish gray (5Y8/1) to light olive gray $(5 Y 6 / 1)$. Non- to partially deformed pumice clasts, which compose from 10 to 20 percent of the unit, typically are 10 to $20 \mathrm{~mm}$ in diameter (locally to $40 \mathrm{~mm}$ ), white (N9), very pale orange (10YR8/2, 10YR8/3), or grayish-orange pink (10R8/2), devitrified (axiolitic, spherulitic), and locally altered to vapor-phase minerals. Argillically altered pumice clasts are moderate pink (5R8/2), pale red (10R7/2), moderate orange pink $(10 R 7 / 4)$, or pale yellowish orange (10YR8/6). Phenocrysts constitute from 10 to 12 percent of the rock (locally 7 to 10 percent) and are predominantly plagioclase, sanidine, and quartz, with subordinate biotite, $\mathrm{Fe}-\mathrm{Ti}$ oxide, and pseudomorphic pyroxene. Lithic clasts that compose from 3 to 7 percent of the rock are scattered throughout the matrix or concentrated in subvertical structures or irregular pods. Lithic clasts typically are smaller than $20 \mathrm{~mm}$ in diameter (locally to $35 \mathrm{~mm}$ ), and predominantly moderate reddish-brown (10R4/6) or moderate brown (5YR4/4, 5YR4.3) siltstone or mudstone, with subordinate volcanic lithologies that include medium gray (N5), grayish-red (5R4/2), or grayish-orange pink (5YR7/2) devitrified lava, grayish-red (10R4/2) to pale red (10R6/2) porphyritic lava, and pale orange (10YR8/2) to grayishorange (10YR7/4) biotite-rich tuff.

\section{Unit 1 - Pumiceous Pyroclastic-Flow Deposit}

This non- to partially welded pyroclastic-flow deposit comprises three macroscopically similar units that are discerned by their lithic clast content and locally separated by thin, ash partings. Local, abrupt changes in the sizes or abundances of lithic or pumice clasts within units may indicate flow unit breaks or intraflow shear. Lithic clasts compose from 1 to 3 percent of the rock in the upper and lower subunits but from 3 to 5 percent in the middle subunit. The upper and lower subunits are indistinguishable without stratigraphic context.

Unit 1 typically has a distinctive very pale orange, yellowish-brown or yellowish-gray matrix color, and abundant, large, light brown, orange-pink, or yellowish-gray pumice clasts. Phenocrysts are predominantly plagioclase, sanidine, and quartz, with subordinate biotite and Fe-Ti oxide, rare pyroxene pseudomorphs, and possible hornblende. Mudstone or siltstone and volcanic lithic clasts occur in all subunits. Siltstone occurs in various shades of dusky yellowish brown (10YR2/2), grayish brown (5YR3/2), pale brown (5YR5/3), dark to pale reddish brown (10R3/4 to $10 \mathrm{R} 5 / 4)$, moderate reddish brown (10R4/6), moderate red (5R4/6), grayish red (5R4/2), very dusky red $(10 \mathrm{R} 2 / 1)$, and grayish black (N2). Volcanic clasts include porphyritic lava in shades of grayish-red (5R4/2 to $10 \mathrm{R} 4 / 2)$, pale reddish-brown (10R5/4), or dark gray (N3); devitrified lava in shades of reddishorange brown (10R5/6), pale red (5R6/2), pale grayishbrown (5YR4/2), grayish-orange pink (5YR7/2), light brownish-gray (5YR6/1), pale yellowish-brown (10YR6/2), and medium light gray (N6); pale yellowish-brown (10YR6/2), light brown (5YR5/6), or grayish-orange pink (10R8/3) tuff; and, in the middle subunit in borehole USW G-2, grayish-black to medium dark gray (N2 to $\mathrm{N} 4)$ scoriaceous glass.

Upper subunit. The matrix is devitrified and where altered or zeolitized, may appear very pale orange (10YR8/2), pale yellowish brown (10YR6/2), yellowish brown (10YR6/3), grayish orange (10YR7/4), pinkish gray (5YR8/1), grayish-orange pink (5YR7/2), yellowish gray $(5 Y 8 / 1,5 Y 7 / 2)$, light olive gray $(5 \mathrm{Y} 6 / 1)$, pale olive (10Y6/2), moderate greenish yellow (10Y7/4), grayish-yellow green $(5 G Y 7 / 2)$, or moderate yellow green $(5 G Y 8 / 3)$. Where locally silicified, the matrix is dense, and dark yellowish brown (10YR4/4) to moderate olive brown (2.5Y4/4) with sparse colorless glass shards. Where vitric or vapor-phase altered, the matrix is very light gray (N8) to pinkish gray (5YR8/1), and contains colorless glass shards. Pumice clasts compose from 15 to 20 percent of the unit, typically have diameters of 10 to $40 \mathrm{~mm}$ (but with clasts to $65 \mathrm{~mm}$ ), and are nondeformed to slightly deformed. Pumice clasts that are altered or zeolitized may appear moderate orange-pink to light brown (5YR8/4 to 5YR6/4), very pale orange 
(10YR8/1, 10YR8/2) grayish orange to moderate yellowish brown (10YR7/4 to 10YR5/4), pale yellowish orange (10YR8/6), yellowish gray to grayish yellow (5Y8/1 to $5 \mathrm{Y} 8 / 4)$, light greenish gray (5GY8/1), grayish-yellow green $(5 \mathrm{GY} 7 / 2)$, moderate yellow green $(5 G Y 7 / 4)$, or pale green $(5 G 7 / 2)$. Nondeformed vitric pumice clasts are white (N9), very pale orange (10YR8/2), or grayish-orange (10YR7/3); deformed vitric pumice clasts are medium gray (N5). Phenocrysts constitute from 7 to 10 percent of the rock. Lithic clasts are typically smaller than $10 \mathrm{~mm}$ (but up to $20 \mathrm{~mm}$ ), predominantly mudstone or siltstone with subordinate volcanic lithologies, compose from 1 to 3 percent of the rock.

Middle subunit. The matrix is devitrified and altered to zeolites or clay, with locally preserved shard textures and silicified horizons. Matrix color may be grayish pink (5R8/2), grayish-orange pink (5YR7/2), moderate orange pink (10R7/4, 5 YR $8 / 4)$, moderate red (5R5/4), very pale orange (10YR8/1, 7.5YR8/2), yellowish gray ( $5 \mathrm{Y} 8 / 1,5 \mathrm{Y} 8 / 2)$, moderate greenish yellow (10Y7/4), greenish gray to moderate yellow green (5GY7/1 to $5 G Y 7 / 3$ ), or light olive (10Y4/4). Devitrified and altered pumice clasts compose from 15 to 25 percent of the rock, are nondeformed to slightly deformed, and typically 5 to $30 \mathrm{~mm}$ in diameter (but occasionally greater than $60 \mathrm{~mm}$ ). Pumice colors include grayish yellow (5Y8/4), pale to moderate greenish yellow (10Y8/2 to $10 \mathrm{Y} 7 / 4)$, grayish-yellow green $(5 \mathrm{GY} 8 / 2)$, very pale orange to grayish orange (10YR8/2 to 10YR7/4), grayish pink (5R8/2), and white (N9). Phenocrysts constitute from 7 to 12 percent of the rock (locally 5 to 7 percent). Lithic clasts are commonly 1 to $10 \mathrm{~mm}$ in diameter (but up to $25 \mathrm{~mm}$, and rarely $65 \mathrm{~mm}$ ), and typically compose from 3 to 5 percent of the rock (locally up to 7 percent). Siltstone and volcanic lithologies occur in subequal amounts.

Lower subunit. The very pale orange (10YR8/2) matrix is devitrified, altered, and lacking shard texture. Pumice clasts have diameters from 5 to $25 \mathrm{~mm}$ (but up to $45 \mathrm{~mm}$ ), compose from 10 to 15 percent of the rock, and are devitrified and altered. Pumice colors include white (N9), very pale orange (10YR8/2, 10YR8/3), light orange brown (5YR7/4), and pale yellowish gray to pale greenish yellow (5Y8/2 to $10 \mathrm{Y} 8 / 2)$. Phenocrysts constitute 7 to 10 percent of the subunit. Lithic clasts, typically from 1 to $5 \mathrm{~mm}$ in size (locally to $12 \mathrm{~mm}$ ), and compose 1 to 3 percent of the rock. Siltstone slightly predominates volcanic lithologies.

\section{Bedded Tuff}

Laminated ash. This finely laminated deposit is a very fine-grained sandy ash that locally contains hints of low-angle crossbedding and that has a color that may be very pale orange (10YR8/2), grayish-orange pink (7.5YR7/2), or medium- to light gray (N6 to N8). Small, altered pumice clasts (1 to $4 \mathrm{~mm}$ diameter) that are locally interbedded with the ash have a grayishyellow color $(5 Y 8 / 3)$. Crystals, predominantly plagioclase, sanidine, and quartz, with trace amounts of biotite, constitute from 2 to 3 percent of the rock. Dendrites of $\mathrm{MnO}$ are common on fractured surfaces.

Reworked(?) tuffs. This subunit is a group of one to five locally preserved, nonwelded, and variably altered deposits. They are described in descending stratigraphic order. Upper pumiceous tuff: A reworked, poorly sorted, altered fall deposit. The matrix typically is moderate red (5R5/4), moderate orange pink (10R7/4), or medium gray (N5). Pumice clasts, which compose from 20 to 70 percent of the deposit, are very pale orange (10YR8/2 to $10 \mathrm{YR} 8 / 1$ ), grayish yellow $(5 Y 8 / 4)$, or moderate greenish yellow (10Y7/4), and have diameters smaller than $7 \mathrm{~mm}$. Phenocrysts of sanidine, plagioclase, quartz, and subordinate biotite and Fe-Ti oxide constitute 5 to 10 percent. Lithic clasts, primarily devitrified rhyolite and possible siltstone, compose from 5 to 15 percent, and have diameters smaller than $3 \mathrm{~mm}$. Upper pyroclastic-flow deposit: Nonwelded, altered and moderate red (5R5/4), pale red (5R6/2), grayish brown (5YR7/3), moderate orange pink (10R7/4), medium gray (N5), or very pale orange (10YR8/1). Pumice clasts compose 10 to 20 percent, are smaller than $10 \mathrm{~mm}$, and very pale orange (10YR8/2), orange pink (10R8/4), grayishorange pink (10R8/2), or white (N9). Phenocrysts of sanidine, plagioclase, quartz and subordinate biotite, pyroxene pseudomorphs, and Fe-Ti oxide, and rare hornblende constitute 5 to 7 percent. Lithic clasts, primarily devitrified volcanic rocks, with rare siltstone and biotite-rich tuff, compose from 3 to 5 percent (locally to 10 percent), and are smaller than $10 \mathrm{~mm}$ (typically smaller than $3 \mathrm{~mm}$ ). Lower pyroclastic-flow deposit: Nonwelded, altered, and very pale orange $(10 \mathrm{YR} 8 / 1)$ to yellowish gray $(5 \mathrm{Y} 8 / 1)$. Pumice clasts compose 10 percent, are smaller than $10 \mathrm{~mm}$ and light greenish gray $(5 \mathrm{GY} 8 / 1)$ to pale greenish yellow (10Y8/2). Phenocrysts of sanidine, plagioclase, quartz, and biotite with subordinate $\mathrm{Fe}-\mathrm{Ti}$ oxide, constitute 7 to 10 percent. Lithic clasts, predominantly devitrified volcanic rocks with subordinate siltstone, are smaller than $7 \mathrm{~mm}$, compose from 10 to 15 percent, and form several normally graded zones. Lower pumiceous tuff: A reworked, poorly sorted, altered fall deposit. The 
matrix typically is moderate orange pink (10R7/4).

Pumice clasts compose from 25 to 80 percent, are smaller than $10 \mathrm{~mm}$, and very light gray (N8), very pale orange (10YR8/2), yellowish gray (5Y8/1), and rarely light olive (10Y5/4). Phenocrysts of sanidine, plagioclase, quartz, and biotite with subordinate Fe-Ti oxide, constitute 5 to 7 percent. Lithic clasts, predominantly devitrified volcanic rocks with rare siltstone, are smaller than $7 \mathrm{~mm}$, and compose from 3 to 5 percent. Basal breccia: A clast-supported deposit of angular fragments of Bullfrog Tuff and, locally, grayish-red (5R4/2) porphyritic lava, medium gray (N5) lava, and grayish-orange (10YR7/4), biotite-rich tuff with diameters that vary from 5 to greater than $50 \mathrm{~mm}$. A moderate red (5R5/4) sandy matrix fills spaces between clasts. 